\title{
Scholarship Repository
}

University of Minnesota Law School

\section{Redesigning Consumer Dispute Resolution: A Case Study of the British and American Approaches to Insurance Claims Conflict}

Daniel Schwarcz

University of Minnesota Law School, schwarcz@umn.edu

Follow this and additional works at: https://scholarship.law.umn.edu/faculty_articles

Part of the Law Commons

\section{Recommended Citation}

Daniel Schwarcz, Redesigning Consumer Dispute Resolution: A Case Study of the British and American Approaches to Insurance Claims Conflict, 83 TUL. L. REV 735 (2009), available at https://scholarship.law.umn.edu/faculty_articles/571.

This Article is brought to you for free and open access by the University of Minnesota Law School. It has been accepted for inclusion in the Faculty Scholarship collection by an authorized administrator of the Scholarship Repository. For more information, please contact lenzx009@umn.edu. 


\title{
Redesigning Consumer Dispute Resolution: A Case Study of the British and American Approaches to Insurance Claims Conflict
}

\author{
Daniel Schwarcz ${ }^{*}$
}

Much of insurance law and regulation is concerned with compensating consumers who have been wrongly denied coverage. But policyholders nonetheless have relatively few realistic options for challenging an insurer's adverse coverage determination. Litigation is often too slow and costly for those who have recently suffered significant financial loss. Meanwhile, the alternative dispute resolution (ADR) options that do exist-such as the conciliation services that insurance regulators offer or the existing variants of insurance arbitration-are generally either ineffective or unavailable for most disputes. This Article proposes a new way forward by looking to the United Kingdom's innovative Financial Ombudsman Service (FOS), which operates parallel to the British financial services regulator and is devoted solely to resolving consumer financial disputes. The comparative success of the FOS, the Article angues, is attributable primarily to the ways in which it blends elements of the individual, uncoordinated insurance ADR schemes that are used in the United States. As such, this Article concludes that American lawmakers can significantly improve insurance compensation by strategically rethinking the institutional architecture of insurance dispute resolution. It also suggests that the British FOS may offer a model for improving consumer dispute resolution in realms beyond insurance.

I. INSURANCE COVERAGE DISPUTES AND LITIGATION .....................741

A. The Risk of Wrongful Coverage Denials........................ 742

B. Coverage Litigation and Compensation........................... 746

* (C) 2009 Daniel Schwarcz. Associate Professor of Law, University of Minnesota Law School. A.B., Amherst College (2000), J.D., Harvard Law School (2003). I would like to thank Kenneth Abraham, Tom Baker, Laura Cooper, Allan Erbsen, Mary Lou Fellows, Susan Franck, Thomas Gallanis, Claire Hill, Alex Klass, Brett McDonnell, William McGeveran, Walter Merricks, Geoffrey Miller, Steven Schwarcz, Gregory Shaffer, Jeffrey Stempel, David Stras, Mark Weidemaier, and participants in the Banking and Consumer Services Junior Scholars Conference at University of Connecticut Law School, the Big Ten Untenured Conference at Indiana University-Bloomington Law School, and the Faculty Works in Progress series at the University of Minnesota Law School. I particularly want to thank Bert Kritzer for introducing me to the Financial Ombudsman Service (FOS) and helping to facilitate a research trip there. Research for this project included an extended visit to the FOS, as well as multiple interviews with various stakeholders in the FOS. It also included numerous interviews with American insurance regulators, which was facilitated by my position as a Funded Consumer Representative for the National Association of Insurance Commissioners. All citations to interviews represent the views of the individual interviewees rather than the organizations with which they are affiliated. Laurie Kellogg, Marie Quasius, Tim Sullivan, Christy Wells, and Megan Yelle all provided excellent research assistance. 
II. ALTERNATIVE APPROACHES IN THE UNITED STATES FOR

RESOLVING CONSUMER INSURANCE COVERAGE DISPUTES 750

A. State-Sponsored Conciliation of Insurance Coverage

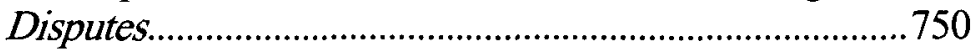

1. An Overview.........................................................750

2. Evaluating the Success of State Conciliation

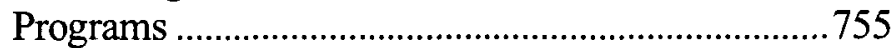

B. Arbitration of Insurance Coverage Disputes....................759

1. An Overview ..........................................................759

2. Evaluating the Success of Insurance Arbitration

III. THE PRIVATE OMBUDSMAN MODEL FOR RESOLVING

INSURANCE DISPUTES AND ITS AMERICAN COUNTERPARTS....... 769

A. The FOS's Process of Dispute Resolution .......................770

1. Stage One: Internal Complaints ..............................771

2. Stage Two: The Frontline Call Center......................772

3. Stage Three: Adjudicator Conciliation.....................772

4. Stage Four: Ombudsman Review ............................776

B. Comparing the American and British Approaches...........779

1. The Similar Elements of Consumer Insurance

ADR in the United Kingdom and the United

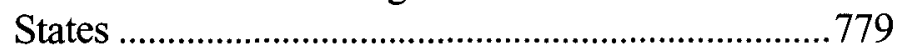

2. The Different Results of Consumer Insurance

$\mathrm{ADR}$ in the United Kingdom and the United

States ..................................................................... 782

IV. EXPLAINING THE COMPARATIVE SUCCESS OF THE BRITISH

PRIVATE OMBUDSMAN MODEL .................................................. 787

A. The FOS's Coordinated ADR Process................................ 788

1. FOS Conciliation in Light of Ombudsman

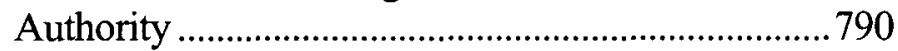

2. The Call Center and the Case Fee ............................795

3. The Internal Complaint Process and

Subsequent FOS Review .........................................796

B. The Role of the Regulator and Private Parties in

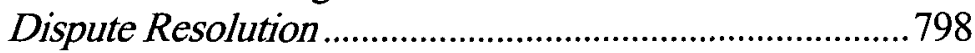

1. The FOS's Independence from the Regulator ..........799

2. The FOS as a Public Entity ....................................8 802

C. The Reasonable Fairness Standard ....................................804

V. FROM THEORY TO REALITY: TOWARDS A PRIVATE

INSURANCE OMBUDSMAN FOR THE UNTED STATES. 
A vanishingly small percentage of disputes between consumers and firms are resolved through litigation.' Unless these disputes carry the prospect of punitive damages or can be aggregated through class actions, they generally do not merit the time, expense, or effort required for ordinary litigation. ${ }^{2}$ Over the last several decades, various alternative dispute resolution (ADR) programs have evolved to help fill this void. ${ }^{3}$ Unfortunately, many of these ADR ventures raise their own serious concerns. For instance, arbitration, the most familiar form of consumer ADR, is often accused of inappropriately favoring repeat players, precluding judicial remedies, and suppressing public information. ${ }^{4}$ Meanwhile, other consumer ADR experiments, such as state-sponsored complaint-conciliation programs, typically face

1. See generally No ACCESS to LaW: Alternatives to the American JUdiCial SYSTEM 3-49 (Laura Nader ed., 1980).

2. See A. Brooke Overby, An Institutional Analysis of Consumer Law, 34 VAND. J. TRANSNAT'L L. 1219, 1277 (2001) (listing devices intended to provide consumers with greater access to courts). Although firms frequently resolve consumer complaints voluntarily, these resolutions are not negotiated in the "shadow of the law" unless the consumer can credibly threaten some form of legal recourse. See Robert H. Mnookin \& Lewis Kornhauser, Bargaining in the Shadow of the Law: The Case of Divorce, 88 YALE L.J. 950, 996-97 (1979). Instead, they are motivated by other considerations, such as firms' reputational interests. See id. at 984; infra note 26 and accompanying text. However, these interests can often create insufficient incentives to (1) resolve consumer disputes or (2) to avoid those disputes in the first place. See infra notes 24-30 and accompanying text.

3. In the 1976 Pound Conference, Chief Justice Warren Burger called for the development of ADR to improve individuals' access to law. See KATHERINE V.W. STONE, PRIVATE Justice: THE LaW OF AlteRnative DisPute RESOlution 2-4 (2000).

4. See, e.g., Mark E. Budnitz, The High Cost of Mandatory Consumer Arbitration, 67 LAw \& ConTEMP. ProBS. 133, 134 (2004); Carrie Menkel-Meadow, Do the "Haves" Come Out Ahead in Alternative Judicial Systems?: Repeat Players in ADR, 15 OHIO ST. J. ON DISP. RESOL. 19, 38-57 (1999); Rex R. Perschbacher \& Debra Lyn Bassett, The End of Law, 84 B.U. L. REv. 1, 30 (2004); Jean R. Sternlight, Creeping Mandatory Arbitration: Is It Just?, 57 STAN. L. REV. 1631, 1649 (2005); Jean R. Sternlight \& Elizabeth J. Jensen, Using Arbitration To Eliminate Consumer Class Actions: Efficient Business Practice or Unconscionable Abuse?, 67 LAw \& CONTEMP. PROBS. 75, 77-92 (2004). But see Samuel Estreicher, Saturns for Rickshaws: The Stakes in the Debate over Predispute Employment Arbitration Agreements, 16 OHIO ST. J. ON DiSP. RESOL. 559, 563 (2001) ("A properly designed arbitration system . . . can do a better job at delivering accessible justice for average claimants than a litigation-based approach."); Peter B. Rutledge, Whither Arbitration?, 6 GEO. J.L. \& PUB. POL'Y 549 (2008) (criticizing the proponents of arbitration reform for advocating for reform without adequate empirical evidence as to the net benefits); Stephen J. Ware, Paying the Price of Process: Judicial Regulation of Consumer Arbitration Agreements, 2001 J. DisP. RESOL. 89, 89-93 (calling attention to the pro-consumer side of arbitration agreements). For an excellent review of the basic terrain of the consumer arbitration debate, see EDWARD Brunet et AL., ARbitration LAW In AMERICA: A CRITICAL AsSESSMENT 127-85 (2006). The recently proposed Arbitration Fairness Act would limit the use of predispute, mandatory arbitration provisions in consumer contracts. Arbitration Fairness Act of 2007, S. 1782, 110th Cong. (2007). 
resource constraints, low claims resolution rates, and their own set of neutrality concerns.

This Article examines a different, and relatively unfamiliar, consumer dispute resolution scheme known as a "private ombudsman." Unlike typical ombudsmen schemes, which help resolve disputes between a private party and government entity, a private ombudsman seeks to resolve disputes between two private parties. ${ }^{6}$ Despite its name, it can be either a public or a private entity. The private ombudsman model first developed as a joint undertaking among three insurers in the United Kingdom. ${ }^{7}$ It has since evolved into the Financial Ombudsman Service (FOS), an independent government entity whose sole function is to resolve British consumers' disputes with their financial service providers. ${ }^{8}$

In many respects, the FOS's institutional design is unremarkable. As with many American regulators, the FOS attempts to conciliate resolutions of consumers' complaints with their financial services providers. ${ }^{9}$ If such conciliation fails, then, as in American forms of

5. See David Serber, Resolution or Rhetoric: Managing Complaints in the California Department of Insurance, in No ACCESS TO LAW: ALTERNATIVES TO THE AMERICAN Judiclal SYSTEM, supra note 1, at 317, 339-40; Eric H. Steele, Fraud, Dispute, and the Consumer: Responding to Consumer Complaints, 123 U. PA. L. REV. 1107, 1177-79, 1185 (1975); William C. Whitford \& Spencer L. Kimball, Why Process Consumer Complaints? A Case Study of the Office of the Commissioner of Insurance of Wisconsin, 1974 WIS. L. REV. $639,669$.

6. Compare Rhoda James, Private Ombuddsmen and Public LaW 3 (1997) (defining a "private ombudsman" as an ombudsman who responds to consumers' complaints about private firms, and who are not necessarily affiliated with those firms), with BLACK's LAW DICTIONARY 1121 (8th ed. 2004) (defining an ombudsman as "[a]n official appointed to receive, investigate, and report on private citizens' complaints about the government"). Numerous American regulators have ordinary ombudsmen. Indeed, the proposed National Insurance Act, which would create an optional federal charter for insurers, contains a provision that would create just such an ombudsman. See Hal S. Scott, Optional Federal Chartering of Insurance: Design of a Regulatory Structure (Harvard Pub. Law Working Paper No. 07-05 \& Networks Fin. Inst. Policy Brief No. 2007-PB-04, 2007), available at http://ssrn.com/abstract $=985579$. The insurance ombudsman would act as a liaison between the Office of National Insurance "and any person adversely affected by the Office's supervisory or regulatory activities, including the failure of the Office to take a requested action." National Insurance Act of 2006, S. 2509, 109th Cong. § 1107(b) (2006).

7. See JAMES supra note 6, at 3 .

8. See Rhoda James \& Philip Morris, The New Financial Ombudsman Service in the United Kingdom: Has the Second Generation Got It Right?, in INTERNATIONAL PERSPECTIVES ON CONSUMERS' ACCESS TO JUSTICE 167, 172-76 (Charles E.F. Rickett \& Thomas G.W. Telfer eds., 2003).

9. Financial Services \& Markets Act 2000, c. 8, § 225 (Eng.). See generally Peter Tyldesley \& Saira Paruk, The Financial Ombudsman Service and General Insurance (Chartered Ins. Inst., Fact Files 2007). On the characterization of state regulators' and the FOS's attempts to promote voluntary settlement as conciliation or evaluative mediation, see infra notes 90 and 212 . 
arbitration, the FOS can issue binding awards, compelling firms to pay up to $£ 100,000$ (roughly $\$ 150,000$ ) in compensation to consumers in a single case.

Despite these parallels to American consumer ADR, the FOS achieves extraordinary rates of voluntary settlement, covers a broad array of disputes, and enjoys remarkable support among British consumers, consumer groups, industry, and academics. " Perhaps for these reasons, the FOS has served as a model for reform in many countries, including Australia, Canada, New Zealand, Ireland, India, and Japan. $^{12}$

This Article's central argument is that the FOS's comparative success is primarily attributable to the ways in which it blends and integrates reforms that have been used independently in the United States. For instance, the FOS combines various ADR strategiesincluding internal complaint handling by firms, state-provided complaint conciliation, and arbitration-into a single coordinated scheme. This institutional architecture allows more involved and expensive $\mathrm{ADR}$ stages to have significant trickle down effects that improve the efficacy of earlier, cheaper stages of the ADR process. Similarly, the FOS's public, but nonregulatory, status blends private arbitration with regulator-provided conciliation in a way that helps the FOS effectively manage decision-maker bias. Finally, the FOS's unique "reasonable fairness" standard blends formal doctrinal precedent with informal industry norms and equitable principles in a way that simultaneously promotes flexibility and consistency. These explanations for the FOS's success motivate this Article's normative claim that American jurisdictions could improve consumer dispute

10. Financial Services \& Markets Act 2000, $\S \S 228-229$; James \& Morris, supra note 8 , at 189 .

11. See infra Part III.

12. See Rashmi Abichandani, Policyholder's Interest Protection: Review of the Insurance Ombudsman Scheme, 5 ICFAI J. INS. L. 45 (2007) (India); Geraint Howells \& Rhoda James, Litigation in the Consumer Interest, 9 ILSA J. INT'L \& COMP. L. 1, 10 (2002) ("In ... Australia, Canada, New Zealand, and the UK, the private ombudsman has proved to be a popular consumer remedy with business, government, and broadly with consumer interests."); Mamiko Yokoi-Arai, A Comparative Analysis of the Financial Ombudsman Systems in the UK and Japan, 5 J. INT'L BANKING REG. 333 (2004) (Japan); Explanatory Materials on the Establishment of the Japan Financial ADR/Ombudsman Study Group 13 (Apr. 18, 2007) (on file with author) (Japan); Financial Services Ombudsman's Bureau of Ireland, About Us - Overview, http:/www.financialombudsman.ie/about-us/ (last visited Nov. 16, 2008) (Ireland). Many other European countries also have ombudsman services that resemble the FOS. For a Web site that details the financial ombudsman schemes of all European countries, see Financial Dispute Resolution Network, Members of FIN-NET, http://ec.europa.eu/internal_market/fin-net/members_en.htm (last visited Nov. 17, 2008). 
resolution dramatically by adopting a more thoughtful institutional architecture within which to deploy their ADR efforts. ${ }^{13}$

This Article focuses on insurance disputes as a case study to advance this argument for two reasons. First, dispute resolution is a core concern of insurance law, as reflected by the FOS's genesis in the insurance industry. Unlike any other financial service provider, insurers' liabilities are contingent on events - such as fires, thefts, health problems, and lawsuits-which are often difficult to specify fully ex ante or to verify accurately ex post. ${ }^{14}$ Yet aggrieved policyholders need compensation quickly while insurers have a natural incentive and capacity to delay litigation as well as claims resolution generally. ${ }^{15}$ Second, and even more importantly, various consumeroriented insurance ADR programs already exist in the United States. The insurance departments of individual states have developed numerous insurance conciliation schemes, and states have experimented with a number of rules and procedures for regulating private insurance arbitration. $^{16}$ These programs serve as a good starting point for reform and a useful basis of comparison for analyzing the private ombudsman model.

This Article proceeds in five Parts. Part I explores the need to modernize the American approach to resolving consumer insurance disputes. Part II critically examines attempts by individual states to promote the ADR of insurance disputes, arguing that these efforts have had limited benefits for consumers. Part III describes the private ombudsman approach, as implemented by the FOS, and compares it

13. This Article is thus consistent with the admonition of one prominent scholar that "the public needs fewer categorical pronouncements and more contextual evaluation" of ADR mechanisms. See Deborah L. Rhode, Frivolous Litigation and Civil Justice Reform: Miscasting the Problem, Recasting the Solution, 54 DuKE L.J. 447, 476 (2004). The Article can thus be framed within the Dispute System Design literature, which explores the "systematic process of creating a dispute resolution system that harnesses the positive aspects of conflict or at least minimizes the negative aspects." Susan Franck, Integrating Investment Treat Conflict and Dispute System Design, 92 MinN. L. REv. 161, 177-80 (2007) (providing an overview of this literature).

14. See KenNETH S. Abraham, Distributing RisK 174, 180-81 (1986); TOM BAKER, INSURANCE LAW AND POLICY 94-96 (2d ed. 2008); Howell E. Jackson, Regulation in a Multisectored Financial Services Industry: An Exploratory Essay, 77 WASH. U. L.Q. 319, 330-31 (1999); Bob Works, Excusing Nonoccurrence of Insurance Policy Conditions in Order To Avoid Disproportionate Forfeiture: Claims-Made Formats as a Test Case, 5 ConN. INS. L.J. 505, 578-88 (1999).

15. See Daniel Schwarcz, A Products Liability Theory for the Judicial Regulation of Insurance Policies, 48 WM. \& MARY L. REv. 1389, 1412-20 (2007); Alan O. Sykes, "Bad Faith" Breach of Contract by First-Party Insurers, 25 J. LEGAL STUD. 405, 407 (1996).

16. See Susan Randall, Mandatory Arbitration in Insurance Disputes: Inverse Preemption of the Federal Arbitration Act, 11 CONN. INS. L.J. 253, 264-92 (2005). 
with American ADR efforts in insurance. It claims that the FOS has many of the same elements as American consumer insurance ADR, yet is wildly more successful. Part IV-the intellectual heart of this Article-offers several explanations for this seeming contradiction, each of which focuses on the way that the FOS blends and coordinates the individual ADR elements of American consumer insurance. Finally, Part V analyzes some potential strategies for implementing an FOS-type scheme in the United States and speculates about the extent to which the FOS might serve as a model for consumer ADR reform in domains beyond insurance.

\section{INSURANCE COVERAGE DISPUTES AND LITIGATION}

All forms of consumer insurance raise a common dilemma. Consumers purchase insurance to protect themselves against significant financial risks. When those risks arise, consumers are often desperately in need of money and ill-equipped to battle with their insurer. Insurers, however, face an inevitable temptation to deny claims aggressively in order to inflate their bottom line. Although the long term reputational consequences of this strategy can be dire, the long term is often long indeed: markets are slow to respond to deficient claims handling given the inherent malleability of insurance contract language, the impediments to full information in consumer insurance markets, and the strategic disadvantages that policyholders face in battling coverage decisions.

One of the primary ways that insurance law addresses this problem is by expanding the remedies that are available to successful plaintiffs in insurance coverage litigation. Unlike ordinary breach of contract cases, aggrieved policyholders can receive attorneys' fees, emotional distress damages, and even punitive damages. ${ }^{17}$ Despite this expansive set of potential remedies, insurance litigation actually provides a relatively poor source of compensation for most aggrieved policyholders. The problem is not that the remedies available through litigation are insufficient-indeed, some might argue that they are excessive. ${ }^{18}$ Rather, the problem lies in the process of litigation, which

17. See Tom Baker, Constructing the Insurance Relationship: Sales Stories, Claims Stories, and Insurance Contract Damages, 72 TEX. L. REv. 1395, 1423-26 (1994).

18. In particular, the availability of emotional distress damages in this context is controversial. Compare id. at 1423 (arguing that insurance "compensation should be as complete as courts can make it" and should therefore include attorney's fees and emotional distress damages) with George L. Priest, The Current Insurance Crisis and Modern Tort Law, 96 YALE L.J. 1521, 1546-47 (1987) (suggesting that emotional distress insurance is generally undesirable for most consumers). 
is a poor mechanism for making any remedy available to aggrieved policyholders. ${ }^{19}$ Whereas litigation is slow, costly, and unpredictable, litigants in insurance coverage cases need compensation quickly, have few resources (financial and emotional) to devote to litigation, and are generally risk-averse.

This Part elaborates on these points. Subpart A first describes the risk of opportunistic breach by insurers. Subpart B then critically examines the ability of litigation to compensate wronged policyholders. Taken together, this Part motivates the remainder of the Article by demonstrating the need to construct $\mathrm{ADR}$ mechanisms that compensate policyholders more effectively than litigation.

\section{A. The Risk of Wrongful Coverage Denials}

Scholars, policymakers, and judges have long recognized that consumer insurance arrangements raise significant concerns about improper claims handling. ${ }^{20}$ Unlike many contracts, insurance policies are sequential and contingent: whereas the policyholder performs routinely by paying premiums, the insurer performs by paying a claim if, and only if, a loss occurs. ${ }^{21}$ Vulnerable parties in sequential and contingent contracts can usually protect themselves by specifying clearly the conditions upon which an obligor's performance is due. ${ }^{22}$ But such protection is difficult, if not impossible, in the insurance context. Because insurance policies concern an entire universe of potential risks, they necessarily incorporate abstract language that leaves insurers with significant contractual discretion. ${ }^{23}$ These structural features of insurance contracts create an inevitable temptation for insurers to adopt overly aggressive claims handling practices: every dollar that an insurer avoids paying in claims adds to its bottom line.

In most cases, of course, insurers resist the temptation to aggressively limit claims payments for business reasons. Insurers'

19. See Sykes, supra note 15 , at 422 (arguing that improving the process for compensating aggrieved policyholders may mitigate the capacity of insurers to exploit litigation delay in order to extract favorable settlements).

20. See, e.g., ABraHAM, supra note 14, at 179 (noting that the insurance dynamic "create[s] special opportunities for inefficient breach").

21. See BAKER, supra note 14, at 94-96; Works, supra note 14, at 578-88.

22. See Charles L. Knapp, Nathan M. Crystal \& Harry G. Prince, Problems in CONTRACT LAW 779 (5th ed. 2003).

23. See ABRAHAM, supra note 14, at 174 ("[I]nsurance policies often are not specific enough to make the rights and obligations of the parties during the claims process crystal clear."); Kenneth S. Abraham, A Theory of Insurance Policy Interpretation, 95 MiCH. L. REV. $531,547-50(1996)$. 
capacity to sell insurance is premised on purchasers' willingness to believe that, should they suffer a covered loss, their insurer will make good on its promise. ${ }^{24}$ But such market forces are not always sufficient to stem insurers' temptation to short-change policyholders. Indeed, significant evidence suggests that prominent national insurers such as Unum/Provident, State Farm, and Allstate have each recently engaged in systematic, national efforts to wrongly cut claims payments to policyholders. ${ }^{2 s}$

One of the primary explanations for this pattern is that insurers' reputations often do not accurately track the true quality of the claims handling practices. ${ }^{26}$ Consumers' impressions of insurers are formed primarily by advertising and word-of-mouth. ${ }^{27}$ But insurance advertising typically relies on abstract promises rather than concrete or

24. For a general discussion of the role of reputation in disciplining sellers' contracting behavior, see Benjamin Klein \& Keith B. Leffler, The Role of Market Forces in Assuring Contractual Performance, 89 J. PoL. ECON. 615 (1981).

25. See Jeffrey W. STEMPel, Litigation Road: The Story of Campbell v. State FARM INSURANCE (2008) (State Farm); John H. Langbein, Trust Law as Regulatory Law: The Unum/Provident Scandal and Judicial Review of Benefit Denials Under ERISA, $101 \mathrm{Nw}$. U. L. REV. 1315, 1317-21, 1339 (2007) (Unum/Provident); Consumer Watchdog, Consumer Advocates Call for Refunds, Rate Reductions, for Allstate Policyholders After Company Releases Internal Documents Revealing Intentionally Underpaid Customers (Apr. 7, 2008), $\mathrm{http} / / / \mathrm{www}$. consumerwatchdog.org/insurance/articles/?storyId=19621 (Allstate).

26. See Schwarcz, supra note 15, at 1413-15. But cf. Sykes, supra note 15, at 418 ("[A]ny insurer who frequently refused to pay covered claims would likely soon develop a reputation for behaving in this fashion and lose customers.").

27. See Schwarcz, supra note 15, at 1413-15 (describing empirical evidence on how consumers make their insurance purchasing decisions). One significant reason that people rely on such information is that "[i]nformation about the reliability of different insurers is hard to come by ... [and] the quality of insurance coverage is almost impossible to assess without an expert." ABRAHAM, supra note 14, at 176. Although the Internet has improved matters in recent years, information about the relative quality of insurers' claims handling is still remarkably unavailable. See Nat'l Ass'n of Ins. Comm'rs, Proposal for Centralized Data Collection, discussed in Sean P. Carr, NAIC Sets September Vote for Market Conduct Plan, BESTWIRE, July 28, 2008, available at http://www.lexisnexis.com/lawschool (search for "BestWire" in "Find a Source"; then search for "NAIC Sets September Vote"); Chad Hemenway, NCOIL Study Expanded To Address NAIC Market Conduct Plan, BESTWIRE, July 11, 2008, available at http://www.lexisnexis.com/lawschool (search for "BestWire" in "Find a Source"; then search for "NCOIL Study Expanded"). One recent proposal to the National Association of Insurance Commissioners (NAIC) would empower regulators to collect and publicly disclose important data elements about the relative quality of insurers' claims handling. Id. These include how often claims are settled within specified time periods and the percentage of claims that are closed with, or without, payment during a policy period. Id. Unfortunately, insurers have bitterly resisted the proposal under the guise of confidentiality and trade secret protection. Letter from Marty Mitchell, Dir., Prod. Policy, America's Health Ins. Plan et al., to Sandy Praeger, President, Nat'l Ass'n of Ins. Comm'rs (June 18, 2008), available at http://www.naic.org/documents/committees_d_data_collection_ comments_comtrades_080618.pdf. 
verifiable information about insurers' relative reliability. ${ }^{28}$ Word-ofmouth also has a limited capacity to transmit reliable information in consumer insurance markets, because consumers typically never experience the most important element of the coverage they purchase - the protection it provides against low-probability, high-cost losses. ${ }^{29}$ Even when consumers do experience a significant loss, they are generally ill-equipped to judge whether their insurer acted properly. $^{30}$

These problems are exacerbated by the fact that consumers typically purchase insurance as part of a larger event or transaction, such as taking a job or buying a home or automobile. Empirical research has consistently found that individuals make market decisions using heuristics that balance "the desire to achieve accuracy with the desire to minimize effort." more complex, decision makers will tend to adopt simpler choice strategies to cope with that complexity.",32 Consumers who bundle insurance decisions with other highly significant choices are consequently likely to rely on disproportionately simple choice strategies when making insurance decisions. ${ }^{33}$ This is particularly true given the inherent complexity of the insurance decision-making process. $^{34}$ In this environment, market forces may actually encourage insurers to provide claims handling that is more aggressive than consumers would purchase were they fully informed and rational. ${ }^{35}$

28. Baker, supra note 17, at 1403-07.

29. See Schwarcz, supra note 15, at 1413-15.

30. See Baker, supra note 17, at 1407-13.

31. See Russell Korobkin, Bounded Rationality, Standard Form Contracts, and Unconscionability, 70 U. CHI. L. REV. 1203, 1223-34, 1226 (2003) (reviewing literature).

32. See id. at 1226.

33. While these choice strategies will clearly encompass factors such as price and the types of coverage available, they will frequently not include such intangible criteria as the quality of different insurers' claims handling practices.

34. Consumers' decision-making processes about insurance are a complicated mix of intuitive, emotional, and rational responses that are susceptible to manipulation. See generally Howard KUnReUther \& Mark PaUly, INSURANCE DeCISION-MaKInG aND Market Behavior (2006); PAul Slovic, THE Perception of Risk 76-77 (2000); David M. Cutler \& Richard Zeckhauser, Extending the Theory To Meet the Practice of Insurance 5 (Apr. 2004), http://www.economics.harvard.edu/faculty/cutler/files/cutler_zeckhauser_theory _and_practice_of_insurance.pdf.

35. See Oren Bar-Gill, Seduction by Plastic, 98 Nw. U. L. Rev. 1373, 1376 (2004); Jon D. Hanson \& Douglas A. Kysar, Taking Behavioralism Seriously: The Problem of Market Manipulation, 74 N.Y.U. L. REv. 630, 745-49 (1999). For empirical evidence of this insurer-side adverse selection, see Baker, supra note 17, at 1400-16. For an argument linking insurer-side adverse selection to the compensation of intermediaries, see Daniel Schwarcz, Differential Compensation and the Race to the Bottom in Consumer Insurance Markets, 14 CONN. INS. L.J. (forthcoming 2009). 
Much of insurance law is designed to respond to these market problems by deterring improper claims handling practices. First, all states have adopted some version of the Model Unfair Claims Settlement Practices Act (UCSPA), which authorizes state regulators to take action in cases of flagrant or repeated unfair claims practices. ${ }^{36}$ Second, many states also rely on ex post, private regulation of claims handling through litigation. ${ }^{37}$ Under the doctrine of bad faith, policyholders are entitled to emotional distress damages and, potentially, even punitive damages if an insurer negligently, knowingly, or recklessly denies a claim without a reasonable basis to do so. ${ }^{38}$

Although these measures help to mitigate the risk that insurers will adopt inefficiently aggressive claims-handling practices, they hardly solve the underlying problem. In practice, most states' UCSPAs have little impact on insurers' claims handling because the Act employs vague standards, ${ }^{39}$ and most insurance regulators do not devote significant resources to its enforcement. ${ }^{40}$ Even when state regulators do attempt to enforce their state's UCSPA, the sheer volume

36. See 2 Official N.A.I.C. Model Unfair Claims Settlement Practices Act (1980). See generally KathleEn HEALd EtTLINGER et al., State InSURANCE REgulation 103 (1st ed. 1995).

37. See generally Schwarcz, supra note 15 (arguing that several doctrines of insurance law, most notably the reasonable expectations doctrine, often constitute the judicial regulation of insurance and that these doctrines have many parallels to products liability law).

38. See generally Symposium on the Law of Bad Faith in Contract and Insurance, 72 TEX. L. REv. 1203 (1994). The standard for defining bad faith differs by jurisdiction. See BAKER, supra note 14, at 111-13.

39. This is not necessarily a defect of the model act, as the proper handling of a claim depends on innumerable factors. Additionally, the UCSPA does admittedly have some clear procedural requirements that states can, and do, monitor through complaint handling. See ETTLINGER ET AL., supra note 36, at 90-97; JEFFREY STEMPEL, STEMPEL ON INSURANCE CONTRACTS $\$ 2.04$ (3d ed. 2006).

40. ETTLINGER ET AL., supra note 36, at 103 ("Many claims people consider private regulation to be the primary method to assure that claims activities are monitored and that consumers are treated in good faith."); see also Moradi-Shalal v. Fireman's Fund Ins. Cos., 758 P.2d 58, 77 (Cal. 1988) (Mosk, J., dissenting) (observing that since the California UCPA was enacted in 1959, there has not been "a single case reported in which the Insurance Commissioner has taken disciplinary action against a carrier for 'unfair and deceptive acts or practices in the business of insurance' involving a claimant"). Given the limited resources of most insurance departments, this balance is sensible. Unlike claims handling, many insurance regulatory issues--such as insurers' solvency, pricing schemes, and forms-cannot be remedied ex post. Faced with a choice, regulators ought to devote their scarce resources to these problems. See Steven Shavell, Liability for Harm versus Regulation of Safety, $13 \mathrm{~J}$. LEGAL STUD. 357, 364 (1984) (discussing the optimal combination of ex ante and ex post regulation). 
of claims that insurers process makes regulating that activity exceptionally difficult. ${ }^{41}$

The doctrine of bad faith similarly faces significant limitations in its capacity to mitigate the risk of improper claims-handling. Most importantly, the doctrine is often unavailable to aggrieved policyholders, as some states have not adopted the remedy and it is preempted by ERISA in all states when the underlying insurance is part of an employee benefit plan. ${ }^{42}$ Even when it is available, the doctrine's deterrent force is undermined by the malleability of insurers' coverage obligations, which blurs the distinction between merely incorrect coverage denials and true bad faith. ${ }^{43}$ Additionally, bad-faith causes of action do not protect consumers with legitimate grievances who cannot credibly threaten to litigate the dispute. ${ }^{44}$ As a result of the underwriting process, insurers are uniquely positioned to discriminate between such policyholders and those who pose credible litigation risks. ${ }^{45}$ Insurers may thereby be able to shortchange nonlitigious policyholders without facing an effective deterrent threat from the doctrine of bad faith.

\section{B. Coverage Litigation and Compensation}

One major function of insurance coverage litigation is to provide a publicly funded route through which insurance policyholders who

41. Insurance regulators do target their market conduct exams to companies or practices that data suggest are particularly problematic. See Nat'l Ass'n of Ins. Comm'rs, Framework for Market Analysis, discussed at http:/www.naic.org/committees_d_mapwg.htm.

42. See Roger C. Henderson, The Tort of Bad Faith in First-Party Insurance Transactions After Two Decades, 37 ARIZ. L. REV. 1153, 1153-56 (1995) (cataloging which states have bad-faith remedies and which do not); Langbein, supra note 25, at 1315, 1317-21, 1339 (arguing that ERISA's exclusive remedial scheme, which generally limits remedies to the recovery of benefits, contributed to the unfair claims practices of the disability insurer Unum/Provident). Without the prospect of owing more in litigation than they would have owed had they paid the claim originally, insurers will not be adequately deterred from denying claims in bad faith. See William S. Dodge, The Case for Punitive Damages in Contracts, 48 DUKE L.J. 629, 698 (1999); Mark Gergen, A Cautionary Tale About Contractual Good Faith in Texas, 72 TEX. L. REV. 1235, 1251 (1994).

43. See Sykes, supra note 15, at 429-43.

44. See R. Ted Cruz \& Jeffrey J. Hinck, Not My Brother's Keeper: The Inability of an Informed Minority To Correct for Imperfect Information, 47 HASTINGS L.J. 635, 674-75 (1996) (describing how firms that can discriminate between informed and uninformed consumers are not constrained by the former in their dealings with the latter).

45. See Schwarcz, supra note 15, at 1407-09.

46. Alternatively, insurers may be able to safely adopt a deny-first, pay-later claims strategy wherein they preliminarily deny uncertain claims, but then reverse course to the extent that a policyholder "reveals" herself to be likely to litigate. Such a strategy would only be sensible, however, if informed policyholders were sufficiently risk-averse that they would generally accept a late settlement offer instead of pursuing punitive damages in litigation. 
have been denied coverage can seek payment of their claims. ${ }^{47}$ Like tort law, insurance coverage law can therefore be conceptualized as a form of publicly mandated and facilitated insurance. ${ }^{48}$ This insurance protects policyholders against the risk, described above, that one's insurer will be overly aggressive in denying coverage relative to consumers' preferences in ideal market conditions. ${ }^{49}$

Ironically, though, insurance coverage litigation typically proves to be a poor insurance mechanism. It is slow, inaccessible, and unpredictable. This point is hardly novel-scholars have long made the same observation about tort law's insurance function. ${ }^{50}$ But because many of the criticisms of tort insurance focus on the incompatibility of the litigation process with efficient insurance, they are directly applicable to insurance coverage litigation. ${ }^{51}$ For instance,

47. Some law and economics scholars have argued that compensation-oriented goals ought not to affect normative legal analysis in tort law because privately provided insurance is cheaper than publicly provided insurance. See, e.g., StEVEn ShaVELl, Foundations of ECONOMIC ANalysis of Law 267-69 (2004); W. KIP Viscusi, Reforming Products LIABILITY 170-72 (1991). Whatever the merits of this argument, it is inapplicable to insurance coverage disputes because no insurer could feasibly provide insurance to cover the risk that another insurer would inappropriately deny coverage. Although one could arguably purchase such coverage from one's own insurer, this argument raises the same problem that creates the underlying risk in the first place: insurance consumers have informational and cognitive limitations that impede their capacity to assess insurers' promises to pay claims, and certain market forces exacerbate these limitations. See supra Part I.A.

48. See, e.g., Patricia M. Danzon, Tort Reform and the Role of Government in Private Insurance Markets, 13 J. LEGAL STUD. 517, 517 (1984) ("[T] he tort system may be viewed as a system of compulsory insurance, with terms of coverage determined largely by the private choices that generate court decisions." (footnote omitted)). Professor Kenneth Abraham has made a similar, though slightly distinct point. See ABRAHAM, supra note 14, at 205. He also suggests that certain doctrines of insurance law-in particular the doctrine of bad faith - often provide the seemingly paradoxical protection of "insurance against the risk of not being insured." Id. His argument, however, is that insurance law sometimes provides insurance against the nonpecuniary consequences of a claims denial. Id. The point here is broader: insurance law provides insurance against the pecuniary (as well as, on occasion, nonpecuniary) risks of being denied coverage.

49. This insurance function resembles the insurance that state insolvency guarantee funds provide to policyholders against the risk that their insurers will be financially unable to pay their claims when they become due. See generally EMMETT J. VAUGHAN \& THERESE M. VAUGHAN, FUNDAMENTALS OF RISK AND INSURANCE 104-05 (9th ed. 2003) (describing guarantee funds as publicly provided insurance).

50. See, e.g., Danzon, supra note 48, at 521; Jeffrey O'Connell, Expanding No-Fault Beyond Auto Insurance: Some Proposals, 59 VA. L. REV. 749, 827 (1973); Stephen D. Sugarman, Doing Away with Tort Law, 73 CAL. L. REv. 555, 593-97 (1985).

51. Of course, some of the problems with "tort insurance" are specific to tort law and have no analog in the insurance coverage context. For instance, some scholars argue that tort law's inquiry into fault is inefficient because insurance should be available even to negligent parties. See O'Connell, supra note 50, at 749. Whatever the merits of this argument in the tort context, it does not translate into the insurance coverage context, where the underlying risk is the wrongfuldenial of a claim. 
litigation is inherently slow, whereas accident victims need compensation quickly and may not have the emotional stamina necessary for litigation, having recently experienced an unexpected loss. ${ }^{52}$ Similarly, the costs of litigation typically make it accessible only to accident victims who can find an attorney willing to take the case on a contingency-fee basis. ${ }^{53}$ Finally, the litigation process produces highly variable and unpredictable damages, whereas accident victims are typically risk-averse. ${ }^{54}$

In fact, litigation may be a particularly unattractive option for accident victims who seek compensation from their own insurer, as compared to tort victims who seek compensation from defendants and their liability insurers. First, litigants in insurance coverage cases typically receive limited insurance payments prior to litigation. ${ }^{55} \mathrm{By}$ contrast, tort victims often receive first-party insurance payments (payments made by their own insurer) independently of any litigation.

52. See O'Connell, supra note 50, at 827 (concluding that "the delay and expense of ascertaining fault" often leads accident victims to choose not to litigate claims). Victims of economic loss - whether they are suing their injurer or their insurer - tend to have much higher discount rates than other litigants because they have immediate financial needs to pay medical bills, fix cars, rebuild houses, and supplement lost income. Sugarman, supra note 50, at 593-94 (explaining that tort plaintiffs often settle cases for less than their full value due to, among other things, "delay" and "urgent financial need").

53. See Jeffrey O'Connell, Statutory Authorization of Nonpayment of Noneconomic Damages as Leverage for Prompt Payment of Economic Damages in Personal Injury Cases, 71 TENN. L. REV. 191, 192 (2003) (explaining that because of the costs and prolonged nature of tort liability litigation, most plaintiff's lawyers paid on a contingency fee basis "probably will not take a case unless they are confident it is likely to lead to at least some substantial payment"). Similarly, accident victims are generally unable to hire legal counsel at an hourly rate because they do not have reserves of funds that can be directed towards legal fees.

54. See O'Connell, supra note 50, at 751 (discussing a 1970 study showing that "[a]bout half of those seriously injured in traffic accidents get nothing at all from tort liability claims"); Sugarman, supra note 50, at 594 ("Tort compensates in an arbitrary, perhaps whimsical, way. ... [L]awyers' talents, plaintiffs' demeanor, defendants' grit, and the idiosyncrasies of jury composition combine to hand similar victims altogether dissimilar results."). Whether accident victims are truly risk-averse may depend on whether they view litigation awards to be gains or to be ways of mitigating losses. According to prospect theory, people tend to be risk-averse when they frame payoffs as gains, but risk-seeking when they frame them as losses. See generally Daniel Kahneman \& Amos Tversky, Prospect Theory: An Analysis of Decision Under Risk, 47 EconometricA 263, 263 (1979). But under the more classical expected utility model, accident victims should be quite risk-averse because the initial dollars they receive will be disproportionately valuable. See David Rosenberg, Decoupling Deterrence and Compensation Functions in Mass Tort Class Actions for Future Loss, 88 VA. L. REV. 1871, 1882 (2002).

55. Interestingly, a new insurance product eases this problem for businesses, providing up to $\$ 250,000$ to pay attorneys' fees for another insurers' denial of coverage. See Susanne Sclafane, New Product Covers Legal Costs If Buyers Decide To Challenge Claim Denial (July 7, 2008), http://www.propertyandcasualtyinsurancenews.com/cms/NUPC /Weekly\%20Issues/Issues/2008/26/News/P26CLAIMSDISPUTE. 
They are therefore comparatively well equipped to manage delays in litigation awards. Second, because insurance coverage suits are not usually initiated until after the claims process has stalled, there is often a significant delay between an insured's need for cash and the initiation of coverage litigation. In tort cases, no such gap exists between the time of injury and the initiation of litigation. Third, plaintiffs in insurance coverage cases are more likely to be risk-averse than tort victims: all such litigants purchased insurance before their loss, whereas only some tort victims were sufficiently risk-averse to purchase first-party insurance. ${ }^{56}$ Finally, the class action mechanism, which helps to fund litigation challenging individually small financial disputes, holds limited promise in the insurance coverage context, as common issues do not often predominate in such cases. ${ }^{57}$

Because litigation is so undesirable for aggrieved policyholders, insurers generally hold an upper hand in settlement negotiations. Insurers' bargaining advantage can lead them to reject fair settlement offers. $^{58}$ It can also cause insurers to delay the litigation process artificially to strengthen this strategic advantage. Such delay may enhance insurers' profits for totally unrelated reasons: investing the "float" on insurance premiums is one of the primary ways that insurers make a profit. ${ }^{59}$ Although most states attempt to counteract this benefit by permitting plaintiffs to recover prejudgment interest, ${ }^{60}$ this offset will not be reflected in settlements if the plaintiff cannot credibly threaten to see the case to trial. Nor could these problems be remedied easily by allowing claimants to sell their insurance coverage claims to third-party firms, because information problems such as adverse

56. At least two objections can be made to this point. First, many purchase insurance because it is required by state law or by their lender. But the bare bones insurance that is required in these contexts is less likely to result in coverage litigation because less is at stake for policyholders in such cases. Second, some who do not purchase insurance simply may not be able to afford it. This, however, likely reflects less risk aversion in many cases: these individuals will tend to value insurance less because they have fewer assets to lose (health insurance may be an exception).

57. Most insurance-related class actions concern nonclaims issues, such as the calculation of premiums or the selling of policies. See Eric Helland \& Jonathan Klick, The Tradeoffs Between Regulation and Litigation: Evidence from Insurance Class Actions, i J. TORT L. iss. 3, art. 2, at 17 (2007), http://bepress.com/jtl/voll/iss3/art2 (collecting instances of insurance class actions in recent years). There are exceptions, like the nonoriginal equipment manufacturer parts class action. See id.

58. See Sykes, supra note 15, at 415.

59. See Richard E. Stewart \& Barbara D. Stewart, The Loss of the Certainty Effect, 4 RISK MGMT. \& INS. REV. 29, 32 (2001).

60. See Sykes, supra note 15 , at 409,413 . 
selection and moral hazard would plague any such market. ${ }^{61}$ Taken together, these factors may explain why it is in insurance coverage cases where one tends to find the most vivid "references to insureds who lose their homes because a claim is denied, who are unable to secure needed medical care, [or] even to a disabled fellow whose "wheelchair was repossessed."

\section{ALTERNATIVE APPROACHES IN THE UNITED STATES FOR RESOLVING CONSUMER INSURANCE COVERAGE DISPUTES}

Over the last century, state lawmakers have developed a patchwork of approaches to improving policyholders' capacity to challenge insurers' claims decisions. Perhaps the most frequently overlooked example is the distinctive brand of conciliation that state regulators use to help resolve disputes between consumers and insurers. $^{63}$ States have also experimented with different types of arbitration schemes in consumer insurance, where federal law favoring arbitration is "inversely preempted" by state insurance law under the McCarran-Ferguson Act. ${ }^{64}$ This Part critically describes these two ADR approaches.

\section{A. State-Sponsored Conciliation of Insurance Coverage Disputes 1. An Overview}

Every state insurance department provides a mechanism by which aggrieved policyholders can lodge complaints about their insurers. $^{65}$ In 2007, the consumer services departments of state insurance regulators "investigated" and "resolved to [their]

61. But see id. at 421-22 (suggesting that assignment of claims could improve insurance markets). The adverse-selection problem stems from the fact that insureds may have much better information than third-party firms about various coverage-related factors, such as the precautions they took and the statements they made to insurers. Id. The moralhazard problem stems from the fact that once a claim was sold, the insured would have little monetary incentive to participate in future litigation. $I d$.

62. Id. at 414-15.

63. Modern commentators seem to have implicitly dismissed the importance of regulator-sponsored conciliation, as this process has received little attention in modern-day insurance law scholarship. But cf. Serber, supra note 5; Whitford \& Kimball, supra note 5.

64. See Randall, supra note 16 , at 264-92.

65. The National Association of Insurance Commissioners (NAIC) provides links to each state's Web site description of how to file a complaint about an insurer. See Nat'l Ass'n of Ins. Comm'rs, Consumer Information Source, https:/eapps.naic.org/cis/ (last visited Nov. 27,2008 ). Virtually all states allow consumers to complain electronically, over the phone, or through ordinary mail. See id. 
satisfaction" over 222,000 consumer complaints. ${ }^{66}$ This figure represents a small fraction of the overall consumer contacts with state insurance departments, most of which are treated as "inquiries" rather than "complaints." ${ }^{, 67}$ Of the roughly 222,000 consumer complaints, approximately 126,000 were deemed "confirmed" under standards developed by the National Association of Insurance Commissioners (NAIC). ${ }^{68}$ Consumers complain about a variety of coverage typeswith Health/Accident, Auto, and Homeowners consistently leading the list. ${ }^{69}$ Complaints usually concern insurers' claim handling practices. ${ }^{70}$

Regulators generally encourage aggrieved consumers to complain directly to their insurer before contacting the state insurance department. $^{71} \quad$ However, few departments appear to turn away complainants who fail to lodge such internal complaints. ${ }^{72}$ Insurers are required to maintain their own internal "complaint handling

66. See Press Release, Nat'l Ass'n of Ins. Comm'rs, NAIC Cites Top Insurance Complaints for 2007 (Jan. 30, 2008), http://www.naic.org/Releases/2008_docs/2007_ complaints.htm.

67. In 2006, for instance, regulators received approximately 400,000 complaints and approximately 2.5 million consumer inquiries. NAT'L ASS'N OF INS. COMM'RS, STATE INSURANCE REGULATORS' RESOURCE MANUAL 11 (2006) [hereinafter RESOURCE MANUAL]. The estimate of complaints in the text may also underestimate the number of complaints as state reporting to the NAIC database is voluntary and only includes closed, confirmed complaints. See NAT'L ASS'N OF INS. COMM'RS, REASONS WhY ClOSED CONFIRMED CONSUMER COMPLAINTS WERE REPORTED AS OF SEPTEMBER 22, 2008, at 1 (2008) (on file with author) [hereinafter REASONS WHY]. States undoubtedly differ about when a consumer complaint is "closed." Moreover, some jurisdictions do not even process some consumer complaints. See Nat'l Ass'n of Ins. Comm'rs, NAIC Consumer Services Survey 24, 36 (Sept. 2008) (presentation slides) (on file with author) [hereinafter Consumer Services Survey].

68. REASONS WHY, supra note 67, at 1 (defining "closed" claims and "confirmed" claims). For a definition of "confirmed" see infra note 97 and accompanying text.

69. NAT'L ASS'N OF INS. COMM'RS, ClOSED CONSUMER COMPLAINTS BY COVERAGE TYPE 1 (2008) (on file with author) [hereinafter COMPLAINTS BY COVERAGE TYPE].

70. REASONS WHY, supra note 67 , at 1 . In $2007,58 \%$ of closed, confirmed consumer complaints involved claims handling, as opposed to "underwriting" or "policyholder service." Id. Of these complaints, $20 \%$ concerned delayed claims, $18 \%$ concerned denied claims, $14 \%$ concerned unsatisfactory settlement offers, and $6 \%$ concerned some "other" claims-handling problem. Id.

71. See, e.g., California Department of Insurance's File a Complaint Page, http://www.insurance.ca.gov/contact-us/0200-file-complaint/index.cfm (last visited Nov. 16, 2008) ("Before you file a complaint with the California Department of Insurance, you should first contact the insurance company, agent or broker in an effort to resolve the issue(s)."); Virginia Bureau of Insurance's File a Complaint Page, http://www.scc.virginia.gov/division/ boi/webpages/boifilecomplaint.htm (last visited Nov. 16, 2008) ("The BOI encourages consumers to try and resolve any problem with their company or agent before contacting the Consumer Services Section.").

72. See sources cited supra note 71 . 
procedures" under each state's UCSPA. ${ }^{73}$ Outside of the health care context, however, most states do not specify the details of this requirement. $^{74}$ Those that do require only that insurers compile basic data about internal complaints, such as their type, the underlying line of insurance, and the company's ultimate disposition. ${ }^{75}$ In most states, only written expressions of a grievance trigger insurers' internal complaint handling obligations. ${ }^{76}$

Most states adhere to a similar protocol for processing consumer complaints that reach their offices. ${ }^{77}$ When a consumer contacts the department, a regulator first determines (1) whether the contact is a complaint or merely an "inquiry," jurisdiction. ${ }^{79}$ If both of these initial hurdles are cleared, the regulator will then investigate complaints that seem potentially legitimate. ${ }^{80}$ In some states, the regulator who initially interacts with the consumer investigates the complaint, whereas in others the complaint is assigned to a designated complaint handler. ${ }^{81}$ The investigation begins with the complaint investigator forwarding the consumer's complaint to the insurer and asking for a response. ${ }^{82}$ An insurer's response may (but

73. See 2 Official N.A.I.C. Model Unfair Claims Settlement Practices Act, supra note 36.

74. The internal complaint rules that govern in the health insurance context are discussed infra text accompanying notes 130-143.

75. See Unfair Trade Practices: Model Regulation for Complaint Records To Be Maintained Pursuant to the NAIC Unfair Trade Practices Act, in 5 NAIC MODEL LAWS, REGULATIONS AND GUIDELINES 884-1 (2007).

76. See 2 Official N.A.I.C. Model Unfair Claims Settlement Practices Act, supra note 36.

77. Interestingly, the current process for resolving complaints is not terribly different than that described by Whitford and Kimball over thirty years ago. See Whitford \& Kimball, supra note 5, at 661-67.

78. Although definitions of a "complaint" differ by state, complaints generally include "any communication that expresses dissatisfaction with a specific insurance company or agent." See NAT'L ASS'N OF INS. COMM'RS, REPORT OF THE NAIC COMPLAINTS HANDLING AND REPORTING STANDARDS SUBGROUP, http://www.naic.org/committees_d_complaints.htm (last visited Jan. 6, 2009) [hereinafter REPORT OF SUBGROUP].

79. Jurisdiction may be limited if the complaint does not concern an insurance product, is governed by another state's laws, or is preempted by federal law. See ETTLINGER ET AL., supra note 36.

80. See Nat'l ASS'N OF InS. Comm'rs, Consumer COMPlaint White Paper 6 (2000) [hereinafter WHITE PAPER]. Thirty-five out of forty states report that their consumer services staff spends at least sixty percent of its time on investigating complaints. Consumer Services Survey, supra note 67 , at 9 . Complaints that seem to be clearly illegitimate are often coded as inquiries rather than complaints. Id.

81. See Consumer Services Survey, supra note 67, at 32.

82. Id. at 29-31; WHITE PAPER, supra note 80, at 7. Some states are moving to an electronic complaint conciliation program. This system operates similarly to the conventional process, but allows for electronic recording of complaints, which individual insurers can then 
need not) be informed by any earlier response it gave directly to the consumer. Because complaint handlers have a limited capacity to investigate or assess cases-they typically handle between 400 and 600 complaints a year ${ }^{83}$ - they rely heavily on the insurer's response to the complaint. When the complaint appears to raise a broad regulatory issue, it is typically referred to a separate market conduct division of the department. This happens very rarely, however: in 2007, complaint handlers referred only $0.4 \%$ of complaints to their market conduct divisions. $^{84}$

Insurance regulators process consumers' complaints for a variety of purposes, including identifying potential regulatory infractions ${ }^{85}$ and publicly disclosing complaint data to help inform consumers. ${ }^{86}$ But the most significant goal of regulators in processing complaints is to help consumers resolve legitimate disputes with their carriers. ${ }^{87}$ Regulators who perform this dispute resolution role generally have no authority to require insurers to settle a claim. ${ }^{88}$ In fact, only a small handful of states even require by statute that state insurance departments provide this ADR service to complaining consumers. ${ }^{89}$

respond to online. See, e.g., Colorado Div. of Ins., Online Complaint Verification, Bulletin No. B-1.13, available at http://www.dora.state.co.us/insurance/regs/bulletin.htm (select "B1.13") (last visited Jan. 15, 2009).

83. Consumer Services Survey, supra note 67, at 15.

84. See NAT'L ASS'NS OF INS. COMM'RS, DisPostTIONS REgaRdng Closed CONFIRMED CONSUMER COMPLAINTS 1 (2008) (on file with author) [hereinafter COMPLAINT DisPOSITIONS].

85. The Unfair Claims Settlement Practices Act erects procedural requirements that insurers must follow in processing a claim and that regulators can monitor through complaints. See supra text accompanying notes 39-41.

86. Different states disclose this information to varying degrees and using varying formats. See generally REPORT OF SUBGROUP, supra note 78.

87. See WHITE PAPER, supra note 80, at 4 ("State insurance departments should provide an avenue for resolution of all consumer complaints."); $i d$. at 8 ("Even if there is no apparent violation of any statute or regulation, it should be the complaint analyst's goal to assist the consumer in resolving the situation."); see also Consumer Services Survey, supra note 67 , at 23 (reporting that almost half of departments view the primary purpose of the consumer services division to be "assist[ing] consumers [in a] time of crisis" rather than "investigat[ing] ... violations of law"); Consumer Services Survey, supra note 67, at 51 (reporting that in a survey of which training programs would be of value to individual departments' consumer services staff, the most common answer, selected by thirty-one of forty responding jurisdictions, was training for "conflict resolution skills").

88. ETTLINGER ET AL., supra note 36, at 103 ("Although many insurance departments have consumer sections available to answer consumers' questions and review claims complaints, the insurance departments are usually not expected to make decisions to resolve the complaints.").

89. But see, e.g., CAL. INS. CODE $\S \S 12921.1(\mathrm{a})(5)(\mathrm{B}), 12921.1(\mathrm{f})(6), 12921.4(\mathrm{a})$ (Deering 2005) (describing a scheme for "complaint mediation [and] investigation," which does not "give the commissioner power to adjudicate claims" but suggests that Department 
Although state regulators use varying approaches in attempting to resolve consumer complaints, the overall process is most aptly described as conciliation or evaluative mediation. ${ }^{90}$ In the case of seemingly nonmeritorious complaints, the conciliation process is fairly straightforward. The regulator contacts the consumer and attempts to explain why the insurer's actions appear warranted. ${ }^{91}$

By contrast, consumer complaints that appear legitimate result in a much more fluid and varied conciliation process, with the regulator pressing the insurer, directly or indirectly, to resolve the matter. Often the complaint investigator simply "discusses" the merits of the complaint with a representative of the insurer in an attempt to extract concessions for the consumer. ${ }^{92}$ In Pennsylvania, complaint investigators facing disputes about policy language may ask the insurer whether there have been earlier instances when that insurer interpreted

employees ought to facilitate "insurer compromise, or other remed[ies] for the complainant"); IND. CODE ANN. §27-4-1-5.6 (LexisNexis 1999) (authorizing commissioner to evaluate consumer complaints and to mediate settlements in appropriate cases); N.J. STAT ANN. $\S 17: 29 \mathrm{~B}-18$ (b)(2) (West Supp. 2008) ("[T] he Commissioner of Banking and Insurance ... shall investigate an insurer" upon receiving a consumer complaint and may "order the insurer to make restitution to the aggrieved person.").

90. There is a large academic debate about how mediation should be conducted and, in particular, whether or not it should be evaluative. See generally Carrie Menkel-Meadow, When Dispute Resolution Begets Disputes of Its Own: Conflicts Among Dispute Professionals, 44 UCLA L. REv. 1871, 1887 (1997) (describing the "heated debate" among dispute professionals concerning "the question whether mediation is facilitative or evaluative or both"). Compare Lela P. Love, The Top Ten Reasons Why Mediators Should Not Evaluate, 24 FLA. ST. U. L. REV. 937, 945-46 (1997) (arguing against evaluative mediation), with Leonard L. Riskin, Understanding Mediators' Orientations, Strategies, and Techniques. $A$ Grid for the Perplexed, 1 HARV. NeGor. L. REV. 7, 23-24 (1996) (suggesting that evaluative mediation can be acceptable), with Jeffrey W. Stempel, The Inevitability of the Eclectic: Liberating ADR from Ideology, 2000 J. DISP. RESOL. 247, 247-48 (arguing that good mediation is both evaluative and facilitative). In order to sidestep this generalized debate, this Article uses the term "conciliation," which overlaps significantly with evaluative mediation in that it involves a neutral third party attempting to bring two parties to a mutually satisfactory settlement, in part by offering an independent evaluation of the underlying dispute. See generally Loukas A. Mistelis, ADR in England and Wales, 12 AM. REV. INT'L ARB. 167, 205 (2001) (noting the similarities between conciliation and evaluative mediation). In their study three decades ago, Whitford and Kimball similarly found that "the best characterization of the [Wisconsin Insurance] Office's role in its routine complaint processing was as a mediator," though, in other cases, "[a] limited adjudicative label best characterizes the Office's dispute settling role." Whitford \& Kimball, supra note 5, at 681 . The NAIC has characterized the process as mediation. See WHITE PAPER, supra note 80 , at 16 (stating that consumer assistance can be provided by "the complaint analyst. . . assum[ing] the role of a mediator").

91. WHITE PAPER, supra note 80, at 8-10.

92. Consumer Services Survey, supra note 67 , at 31 . Ideally, complainants receive periodic updates from the complaint handler as the investigation proceeds. See WHITE PAPER, supra note 80 , at 7 . 
the relevant clause differently. ${ }^{93}$ Where there is tension between an adjuster and a policyholder, the Pennsylvania Department will often propose that a different adjuster be assigned to review the case afresh. ${ }^{94}$ States may also attempt to encourage settlements in other ways. For instance, Minnesota generally does not include complaints that are resolved within three days in the tallies of complaints that it reports to the public. ${ }^{95}$ In general, though, states are careful not to do anything in the conciliation process that could be construed as a "regulatory decision," which might be appealable to the courts. ${ }^{96}$

\section{Evaluating the Success of State Conciliation Programs}

Although state-sponsored insurance conciliation is a valuable resource for consumers, it suffers from three interrelated limitations: it is frequently unsuccessful at convincing insurers to compromise, state insurance departments often have inadequate resources to review claims meaningfully, and review may tend to be biased in favor of insurers.

The first of these limitations is the most significant. Regulatory complaint handlers are often unable to resolve complaints in which the state insurance department "upheld the consumer's complaint position" under NAIC standards." In fact, according to states' complaint data, regulators do not convince insurers to alter their original position in the majority of cases where consumer complaints are "confirmed." Importantly, this data is merely suggestive, as

93. See Interview with Ronald Gallagher, Deputy Ins. Comm'r for Consumer \& Producer Servs., Pa. Ins. Dep't (Mar. 30, 2008).

94. See id.

95. See Interview with Robert Commodore, Dir. of Mkt. Assurance, Minn. Dep't of Commerce (Dec. 12, 2007).

96. See Interview with Ronald Gallagher, supra note 93.

97. See REASONS WHY, supra note 67 , at 1 . Under NAIC standards, consumer complaints are "confirmed" if the regulator codes the complaint with a "disposition code" that is not on the following list: "(1) Unable to assist; (2) Cancellation Upheld; (3) Nonrenewal Upheld; (4) No Action Requested/Required; (5) Referred to Proper Agency/Section; (6) Company In Compliance; (7) Company Position Upheld; (8) No Jurisdiction; or (9) Insufficient Information." Id. A new proposal would require regulators to directly determine whether the complaint was confirmed, rather than making an inference about the complaint based on the above scheme. See Bob Lisson \& Jack Chaskey, Project Summary: Complaint Handling and Reporting Standards (July 29, 2008) (on file with author) (reporting that the Market Analysis Priorities (D) Working Group had adopted a consensus definition of "confirmed complaint").

98. In 2007, there were approximately 68,000 confirmed complaints where departments reported that they "Advised Complainant," the complainant "Entered into Arbitration/Mediation" or "Filed Suit/Retained Attorney," "Information [was] Furnished/Expanded," the complaint involved a legal or factual issue, or they were otherwise 
regulators have widely acknowledged that the underlying data elements are overlapping, confusing, and ambiguous. ${ }^{99}$ Nonetheless, the data strongly suggests that regulators are often quite limited in their capacity to convince insurers to compromise on seemingly legitimate consumer complaints. Interestingly, state-sponsored mediation programs that departments coordinate after a natural disaster ${ }^{100}$ enjoy much better rates of claim resolution. ${ }^{101}$

A second, and likely related, limitation of regulator conciliation is that the consumer affairs divisions of many state insurance departments are significantly resource-constrained, ${ }^{102}$ resulting in vast differences among the states regarding "the extent of services

"Unable to Assist." See COMPLAINT DiSPOSITIONS, supra note 84 , at 1 . These figures do not
even include complaints where regulators report only that they were "Unable to Assist,"
because such complaints are not deemed to be "confirmed." By contrast, there were
approximately 62,000 instances in which departments reported a "Compromised
Settlement/Resolution," "Additional Payment," "Coverage Extended," "Claim Reopened,"
"Claim Settled," "Delay Resolved," "Cancellation Notice Withdrawn," "Nonrenewal Notice
Rescinded," "Nonforfeiture Problem Resolved," "Deductible Refunded," "Endorsement
Processed," "Policy Issued/Restored," "Refund," "Premium Problem Resolved," "Rating
Problem Resolved," or a "Recovery." See id. Whitford and Kimball also suggested that
regulators had difficulty convincing insurers to change their positions through mediation.
Whitford \& Kimball, supra note 5, at 665 (finding that if the insurer did not voluntarily
change its position after receiving a copy of the consumer's complaint, then "[t]he
investigator almost always concluded solely on the basis of the complaint and the initial reply
[from the insurer] that the complaint was without merit or that factual or legal issues underlay
the dispute the Office could not or should not resolve").

99. Currently the Market Analysis and Priorities Working Group of the NAIC is working to develop better codes for the entire complaint data collection effort. See Nat'l Ass'n of Ins. Comm'rs, Market Regulation and Consumer Affairs (D) Committee, http://www.naic.org/committees_d.htm (last visited Nov. 16, 2008).

100. These programs are typically conducted by external organizations with which the department has a standing agreement. Elizabeth Baker Murrill, Mass Disaster Mediation: Innovative $A D R$, or a Lion's Den?, 7 PEPP. DiSP. RESOL. L.J. 401, 404-05 (2007). Some insurance departments have also experimented with external mediation in disputes that do not involve catastrophes. See Okla. Ins. Dep't, EAGLE Mediation, http://www.ok.gov/oid/ consumers/EAGLE_Mediation/index.html (last visited Feb. 13, 2009) (describing the Oklahoma Insurance Department's EAGLE Mediation program, which assists consumers whose complaints the department could not resolve because of a disputed question of fact).

101. The first such program in Florida handled around 2400 disputes and achieved a settlement rate of ninety-two percent, leading the Florida department to label the program "a resounding success." Murrill, supra note 100, at 404-05. Since then, several other states have adopted similar catastrophe-based insurance mediation programs, which also appear to resolve a high percentage of claims. Id. As Murrill noted, this success is partially offset by the prospect that such mediations may present significant risks for uninformed consumers. See id. at 402.

102. ETTLINGER ET AL., supra note 36 , at 103 ("Insurance departments . . are not equipped to deal with the volumes of consumers' claims complaints that are generated daily."). 
provided" in attempting to resolve consumer complaints. ${ }^{103}$ In fifteen of forty states that responded to an NAIC survey, complaint handlers have caseloads of 600 or more complaints a year, and in seven of those states complaint handlers have caseloads of over 1000 complaints a year. ${ }^{104}$ Such caseloads obviously limit the extent to which a complaint handler can carefully scrutinize a consumer's complaint or an insurer's response. In some cases, they also lead to consumer complaints simply being ignored. Indeed, forty-five percent of states responding to the NAIC survey reported that they do not process all consumer complaints that they receive. ${ }^{105}$ One 1998 investigation found that, due to resource constraints, the Indiana Department of Insurance "rarely does anything in response" to consumer complaints. ${ }^{106}$ As the insurance commissioner at the time explained, "without a significant increase in staff, many complaints 'can't get the attention they deserve." $" 107$

One common way that departments adjust their complaint handling role due to resource constraints is to artificially, and confusingly, limit the types of complaints that they handle. For instance, many departments state that they will not attempt to resolve complaints involving "legal or factual issues." In 2007, complaint handlers turned away approximately fifteen to twenty percent of consumer complaints on that basis. ${ }^{108}$ Many other consumers presumably did not seek assistance from their regulator precisely because they already knew of this limitation, which is often prominently announced on department Web sites. ${ }^{109}$ Some departments justify this limited role on grounds of a lack of authority, as opposed to resource constraints. ${ }^{110}$ The view of these departments is

103. WHITE PAPER, supra note 80 , at 28 ("[I]t is clear [that] differences exist between states regarding, among other things, the extent of services provided and the procedures relating to the investigation and resolution of consumer complaints.").

104. Consumer Services Survey, supra note 67, at 15. By contrast, fourteen of those states reported that complaint handlers enjoyed caseloads of fewer than 400 cases a year. Id.

105. Id. at 24 .

106. See Scot J. Paltrow, A Matter of Policy: How a State Becomes Popular with Insurers-But Not Consumers, WALl ST. J., Jan. 14, 1998, at A1.

107. See id. Even when complaints were attended to, the consumer consultants on the staff did "little more than forward complaints to the companies." Id.

108. See COMPLAINT DisPOSITIONS, supra note 84, at 1-2.

109. See, e.g., California Department of Insurance's File a Complaint Page, supra note 71 (announcing that "Consumer Services cannot ... resolve a dispute that is a question of fact"); Maine Bureau of Insurance's Filing Complaints Page, http://www.maine.gov/pfr/ insurance/complaint.htm\#a (last visited Nov. 16, 2008).

110. See Whitford \& Kimball, supra note 5, at 665 (describing the letter that the department sent to consumers when a dispute rested on a factual or legal issue, justifying 
that such questions of fact or law fall outside of the insurance department's "regulatory" authority." $\quad$ But it is hard to understand what this means, because almost all complaints that implicate regulatory issues can also be described as involving either a legal or factual dispute. For instance, a complaint that an insurer improperly denied a claim could reveal a potential violation of the insurer's regulatory obligation to "adopt and implement reasonable standards for the prompt investigation and settlement of claims" or could be described as a mere question of law or fact. ${ }^{12}$ Moreover, no laws prevent regulators from attempting to resolve disputes that do not involve regulatory violations, and most insurance departments report that they do indeed attempt to resolve such complaints. ${ }^{113}$

Finally, regulator conciliation of consumer complaints may tend to be biased in favor of insurers. To some extent, this possibility is correlated with the prospect of regulatory capture, which many have argued is a significant problem in the insurance industry. ${ }^{14}$ But there are particular reasons why regulatory complaint handlers may tend to favor insurer interests in processing consumer complaints. As noted above, virtually any insurance complaint can be framed as either a legal or factual conflict, allowing complaint handlers to disregard certain complaints in a way that may reflect conscious or unconscious biases. One study of the California Department of Insurance in 1980 noted just such a trend, reporting that complaint handlers would disregard complaints based on "the personality of the complainant and the estimated straightforwardness of the case."115 It also reported that

refusal to proceed further by observing that "the Office was a regulatory not a judicial agency").

111. See id;; Nat'l Ass'n of Ins. Comm'rs, Mkt. Analysis \& Priorities Working Group, Adopted Definitions of Dispositions (on file with author).

112. 2 Official N.A.I.C. Model Unfair Claims Settlement Practices Act, supra note $36, \S 4$.

113. WHITE PAPER, supra note 80, at 15 .

114. See BAKER, supra note 14, at 53 (noting that while "[t]here has been no systematic, scholarly study of the effectiveness of state regulation of insurance forms," most assume that such regulation is inadequate); Robert E. Keeton, Insurance Law Rights at Variance with Policy Provisions, 83 HARv. L. REv. 961, 967 (1970) ("Regulation is relatively weak in most instances, and even the provisions prescribed or approved by legislative or administrative action ordinarily are in essence adoptions, outright or slightly modified, of proposals made by insurers' draftsmen."); Susan Randall, Insurance Regulation in the United States: Regulatory Federalism and the National Association of Insurance Commissioners, 26 FLA. ST. U. L. REV. 625, 639 (1999) (arguing that "the problem of capture as it exists in other regulatory contexts is minimal when compared to the problem in the insurance industry" for various reasons, including that "[t]he industry directly funds" the National Association of Insurance Commissioners).

115. Serber, supra note 5, at 329-31. 
this reasoning was used to "deselect complaints" lodged by "people who [could] be fooled or who [would] not or [could not] challenge the staff." 116 A more recent article similarly raised concerns about the fairness of disaster insurance mediation specifically, suggesting that the disparity in sophistication between insurers and consumers results in the process significantly favoring insurers. ${ }^{17}$

In sum, while the conciliation services provided by state insurance regulators are no doubt beneficial for consumers, they are also quite limited. Regulators are often unable to convince insurers to compromise on seemingly legitimate consumer complaints, they have inadequate resources to devote to these complaints, and complaint handlers' neutrality is not guaranteed.

\section{B. Arbitration of Insurance Coverage Disputes \\ 1. An Overview}

Predispute, mandatory arbitration provisions are seemingly ubiquitous in consumer contracts, regularly appearing in agreements governing cell phone plans, credit cards, rental cars and countless other consumer transactions. ${ }^{18}$ This proliferation of arbitration requirements is largely attributable to the Federal Arbitration Act (FAA), which prevents states from significantly interfering with arbitration agreements. $^{119}$ But unlike all other fields of consumer law, the FAA poses no obstacle to states regulating or prohibiting insurance-specific arbitration laws: under the McCarran-Ferguson Act, state laws that regulate insurance trump federal statutes of general applicability, such as the FAA. ${ }^{120}$ This unique legal backdrop has allowed states to regulate insurance policy terms governing arbitration. ${ }^{121}$

116. Id. at 331 .

117. See Murrill, supra note 100, at 403.

118. See Linda J. Demaine \& Deborah R. Hensler, "Volunteering” To Arbitrate Through Predispute Arbitration Clauses: The Average Consumer's Experience, 67 Law \& CONTEMP. PROBS. 55, 57 (2004); William J. Woodward, Jr., Finding the Contract in Contracts for Law, Forum and Arbitration, 2 Hastings Bus. L.J. 1, 1 (2006); cf. Florencia MarottaWurgler, "Unfair" Dispute Resolution Clauses: Much Ado About Nothing?, in OMRI BENSHAHAR, BOILERPLATE: THE FOUNDATION OF MARKET CONTRACTS 45 (2007) (finding limited evidence of strategic use of arbitration clauses in a sample of end-user license agreements).

119. See BRUNET ET AL., supra note 4, at 157-59 (describing various state efforts to protect consumers from mandatory arbitration and noting that most of them "have been rendered substantially irrelevant by [a] series of Supreme Court decisions”).

120. See 15 U.S.C. $\S 1012$ (b) (2006).

121. See Randall, supra note 16 , at 264. 
States have used this capacity to experiment with insurance arbitration schemes in a few key areas. ${ }^{122}$ The most long-standing example is the "appraisal" clause found in virtually all auto and homeowners policies. ${ }^{123}$ These clauses originally appeared in statemandated fire insurance policies and continue to be mandatory in most states. ${ }^{24}$ Under the appraisal clause, two independent experts, each of whom is selected by one of the parties, resolve disputes about the extent of loss to insured property. ${ }^{125}$ Appraisal is not available to resolve disputes about the existence of coverage. ${ }^{126}$ In general, the appraisal process is highly informal and involves the selected appraisers independently investigating the loss and reaching a joint conclusion. ${ }^{27}$ Parties generally bear the costs of hiring their appraiser. $^{128}$ In many states, appraisal can be waived by one, or both, parties, who can opt for litigation rather than appraisal at the time the dispute arises. ${ }^{129}$

States have more recently experimented with insurance arbitration when it comes to certain limited health insurance

122. This Article adopts a broad definition of "arbitration" that encompasses all instances in which a private third party is endowed with the power to bind one, or both, disputants to a particular outcome.

123. See generally Richard C. Bennett, Use and Purpose, in InSURING REAL ProperTy $\S 30.01$ (Stephen A. Cozen ed., 2003); Timothy P. Law \& Jillian L. Starinovich, What Is It Worth? A Critical Analysis of Insurance Appraisal, 13 CoNN. INS. L.J. 291 (2007). In the auto insurance context, appraisal clauses may accrue to the benefit of auto shops, not consumers, if they involve disputes about the charge that the repair shop sends the insurer. But appraisal can also benefit consumers in total loss situations or other cases in which they are directly paid by insurers for their losses.

124. See, e.g., CAL. INS. CODE $\S 2071$ (Deering 1992) (fire insurance policy with appraisal provision); N.C. GEN. STAT. $\S 58-44-15$ (2007) (same). Standard fire insurance policies set a floor for property fire insurance coverage in most states. See BAKER, supra note 14 , at 350; Bennett, supra note 123 . Some states explicitly require by statute that consumer property insurers offer appraisal to resolve all disputes over the actual cash value of damage to property. See, e.g., ALASKA STAT. $\$ 21.89 .035$ (LexisNexis 2002) (mandating appraisal clauses in all auto and property coverage policies). Where there is no statutory mandate, it is still highly unlikely that a state regulator would approve a consumer property insurance form that did not contain an appraisal clause.

125. Although each party chooses its own appraiser, both must be competent and independent, and they are frequently licensed by state regulators. See Bennett, supra note 123; Law \& Starinovich, supra note 123, at 318-19.

126. Law \& Starinovich, supra note 123 , at 295.

127. See id. at 292-93; id. at 299 ("[A]rbitration provisions do not require the procedural formality of arbitration proceedings."). Although the basic structure of the appraisal process is uniform, some of the details differ by state. See id. at 293 ("Insurance policies typically provide little instruction or guidance about how an appraisal is to be conducted, and state laws and precedent vary in their treatment of such provisions."). Generally appraisers choose an umpire to resolve disagreements between them. Id. at 294.

128. Bennett, supra note 123; Law \& Starinovich, supra note 123, at 294.

129. See Bennett, supra note 123. 
disputes. $^{130}$ Most states require health insurers ${ }^{131}$ to offer policyholders "external review" of any coverage denial that is predicated on the insurer's determination that a treatment is not "medically necessary."132 Such external review is performed by independent doctors, who are part of external review organizations (EROs). ${ }^{133}$ States typically certify EROs and nominally monitor their decisions for quality and objectivity. ${ }^{134}$ Additionally, states generally specify the procedures of external review, such as what evidence can be considered and when hearings can be held. ${ }^{135}$ The external review process is paper-based, involving the ERO doctors reviewing the medical evaluations of the insurer and any independent doctors and assessing whether the insurer has followed proper procedures. ${ }^{136}$

States typically require that complainants first exhaust their insurer's internal review procedures, before invoking external review. ${ }^{137}$ Unlike the internal review procedures in other lines of insurance, ${ }^{138}$ most states mandate relatively well-developed internal grievance processes for health insurers. ${ }^{139}$ The documents, information, and

130. Rush Prudential HMO, Inc. v. Moran, 536 U.S. 355, 377-80 (2002), distinguishes external review from arbitration in assessing whether ERISA preempts external review because it is an "alternative remedy" for ERISA violations. Regardless, external review clearly fits the broad definition of arbitration used in this Article. See discussion supra note 122.

131. Under ERISA, self-funded employer plans are not subject to these laws. See Rush, 536 U.S. at 371-72 n.6.

132. See generally Nan D. Hunter, Managed Process, Due Care: Structures of Accountability in Health Care, 6 Yale J. Health Pol'y L. \& ETHiCs 93, 128-40 (2006). In 2006, over forty states required such external review. Id. at 128-32. Recently, even more states have adopted similar laws. See Health Carrier External Review Model Act, in NAIC Model LAwS, REgulations AND GuIDELINES, supra note 75, at 75-1. A few states have also extended the breadth of external review to include other types of coverage determinations, including determinations that a treatment is experimental. Hunter, supra, at 129.

133. Hunter, supra note 132, at 122-27.

134. See id. at 156 . Such monitoring can be performed by state agencies, designated panels, or private accreditation organizations. See id; Leatrice Berman-Sandler, Independent Medical Review: Expanding Legal Remedies To Achieve Managed Care Accountability, 13 ANNALS HEALTH L. 233, 239 (2004).

135. See Hunter, supra note 132, at 132-36. "External Review laws [therefore] use process itself as a structure of accountability." Id. at 143.

136. Id.

137. Health Carrier External Review Model Act, supra note 132, § 7.

138. See supra text accompanying notes 74-75.

139. The NAIC's model act governing health care grievances requires insurers to include a significant amount of information in internal grievance-handling decisions sent to insureds, including the titles and credentials of the people reviewing the grievance, a statement of the reviewers' understanding of the grievance, the reviewers' decision and rationale in sufficient detail for the insured to respond further to the insurer's position, and references to all evidence and documentation used as the basis for the decision. Health Carrier Grievance Procedure Model Act, in NAIC Model LaW, Regulations AND 
correspondence generated during this process are usually, but not always, part of any record that is before an external review panel. ${ }^{140}$ In most states, consumers are charged little or no fee for external review $^{141}$ and they generally do not hire lawyers. ${ }^{142}$ Policyholders in most states do not need to invoke external review as a prerequisite to suing their insurer. ${ }^{143}$

Outside of appraisal and external review, states have generally used their insurance-specific exemption from the FAA to prohibit or otherwise restrict arbitration. Approximately twenty jurisdictions prohibit predispute, mandatory arbitration provisions in insurance policies. $^{144}$ Other states limit certain types of arbitration clauses, requiring particular procedural safeguards or notice requirements for arbitration agreements in health insurance, life insurance, or other policies. $^{145}$ Significantly, a newly developed Interstate Insurance Compact — which establishes and enforces uniform product standards for thirty-two states in life insurance, annuities, disability insurance, and long-term-care insurance ${ }^{146}$-bans all predispute, binding arbitration provisions. ${ }^{147}$ Although many states and territories do not explicitly prohibit arbitration provisions in consumer insurance policies, insurers in those states usually do not include general

GUIDELINES, supra note 75 , at $72-1, \S 6(\mathrm{G})(1-5)$. At least one state has adopted this aspect of the NAIC model act verbatim. See Neb. Rev. STAT. ANN. § 44-7308 (LexisNexis 2005). Many other state statutes require insurers to explain grievance decisions to insureds, but they are often not as specific as the NAIC model. See, e.g., FLA. STAT. ANN. $§ 641.511$ (f) (West 2005) (requiring only that insurers establish procedures to "notify the [insured] of a final decision in writing").

140. E.g., Fla. Stat. AnN. $§ 408.7056$ (West Supp. 2004). But see MinN. Stat. $\S 62 \mathrm{Q} .73$ (2005) (requiring insurers to provide to external review entity only "any information [the insurer] wish[es] to be considered"). The NAIC's model act for external review requires insurers to provide to the external review organization "the documents and any information considered in making the adverse determination or final adverse determination." Health Carrier External Review Model Act, supra note 132, § 8(E)(1).

141. Health Carrier External Review Model Act, supra note 132, at 75-1, § 12.

142. Berman-Sandler, supra note 134, at 261-62; Hunter, supra note 132, at 134.

143. See Hunter, supra note 132 , at 137-38.

144. See Randall, supra note 16 , at $270-71$ (citing eight jurisdictions that explicitly prohibit arbitration clauses in insurance policies and eleven that have the effect of doing so by explicitly excluding insurance from their state versions of the FAA).

145. See id. at 272-73.

146. See generally Interstate Insurance Product Regulation Commission Web Site, $\mathrm{http}: / /$ www.insurancecompact.org/index.htm (last visited Nov. 16, 2008).

147. See Interstate Insurance Product Regulation Commission, Record, http://www. insurancecompact.org/compact_rimkng_record.htm (last visited Nov. 16, 2008) (including in every Policy Standard a provision that "[o]nly arbitration provisions that permit voluntary post-dispute binding arbitration shall be allowed in policy forms"). 
arbitration provisions in their policies, ${ }^{148}$ outside of managed health care $^{149}$ and uninsured/underinsured automobile coverage. ${ }^{150}$

To be sure, several enterprising states have more affirmatively experimented with consumer insurance arbitration schemes. For instance, four of the dozen "no fault" auto insurance states require auto insurers to participate in an arbitration scheme. ${ }^{151}$ Additionally, at least one state, Delaware, requires that insurers make arbitration available to

148. To be sure, some insurers do use arbitration provisions in their policies, and some assert that this trend is on the rise. Randall, supra note 16, at 253-54 ("Arbitration provisions are appearing with increasing frequency in all types of insurance policies."); see Public Citizen, Arbitration Clauses in Insurance Contracts: The Urgent Need for Reform, http://www.citizen.org/print_article.cfmID=6561 (last visited Nov. 16, 2008) ("The growing use of binding, pre-dispute arbitration clauses poses a huge threat to insurance consumers."). Whatever the trend, general arbitration clauses are certainly not the norm in most basic consumer insurance policies, including homeowners, renters, and auto. See ALAN I. WIDISS \& JeFFrey E. ThOMAS, UNDERINSURED Motorist INSURANCE $\$ 22.3$ (2005) ("[I]n the absence of statutory mandates, the insurance industry has not introduced arbitration clauses in other types of coverage [aside from uninsured/underinsured motorist coverage]."); Ins. Servs. Org., Standardized Insurance Policy Forms, available at http://www.iso.com/ Producs/ISOnet/Forms/Forms-Library-on-ISOnet-standardized-insurance-policy-forms.html (last visited Jan. 30, 2009); see also Kenneth S. Abraham \& J.W. Montgomery, III, The Lawlessness of Arbitration, 9 CONN. INS. L.J. 355, 358 (2003) ("Few standard-form primary commercial liability and property insurance policies issued by American insurers contain arbitration clauses."). It is difficult to explain insurers' apparent ambivalence to arbitration in states that do not limit the use of these clauses. While insurers may fear triggering enhanced regulatory or judicial scrutiny, they may also be responding to consumer demand or be wary of schemes that make policyholders more likely to challenge coverage decisions.

149. See Elizabeth Rolph, Erik Moller \& John E. Rolph, Arbitration Agreements in Health Care: Myths and Reality, 60 LAW \& CONTEMP. ProBs. 153, 173 (1997) (finding that most HMOs require arbitration of contract disputes with enrollees, while PPOs do not).

150. For uninsured/underinsured coverage, policy provisions usually require the arbitration of disputes involving (1) whether the policyholder could recover damages from the uninsured/underinsured driver and (2) how much he could recover. Alan I. Widiss, The Enforceability of Arbitration Terms in Uninsured Motorist Coverages and Other Form Contracts, 66 IOWA L. REV. 241, 246 (1981). Insurers popularized this innovation in order to avoid conflicts of interest that are distinctive to uninsured/undersinsured coverage. See id. at 245 (exploring how insurers may simultaneously have an incentive to show that (1) their policyholder, rather than the underinsured/uninsured driver, was at fault in the accident, and (2) the underinsured/uninsured driver, rather than the policyholder, was at fault in the accident, and how insurers solved this conflict by requiring arbitration of disputes concerning the first issue). Some states regulate the arbitral procedures and selection of arbitrators for uninsured/underinsured arbitration. See, e.g., Rules for Arbitration of Supplementary Uninsured/Underinsured Motorist Insurance Disputes and Uninsured Motorist Insurance Disputes in the State of New York, http://www.adr.org/sp.asp?id=22086 (last visited Nov. 16, 2008).

151. See Haw. Rev. Stat. ANN. § 431:10C-213 (LexisNexis Supp. 2008); MinN. STAT. $\S 65 B .525$ (2005); N.J. STAT. ANN. § 39:6A-5(i) (West Supp. 2008); N.Y. INS. LAW $\S 5106$ (McKinney 2000). Two other states also have procedures for arbitration of no-fault claims in place, but require the assent of both parties. See DEL. CODE ANN. tit. 21, § 2118(j)(5) (1999); D.C. CODE ANN. § 31-2405 (LexisNexis 2001). See generally MATTHEW BENDER, NO-FAULT AND UNINSURED MOTORIST AUTOMOBILE INSURANCE $§ 15$ (2008). 
consumers in disputes arising out of auto, homeowners, and health insurance..$^{152}$ In both instances, states employ the same basic consumer protections that exist in the external review and appraisal contexts. First, in two of the four "no fault" arbitration states, the consumer can opt for litigation rather than arbitration after the dispute arises. ${ }^{153}$ The same consumer choice at the time of dispute is built into the Delaware scheme. $^{154}$ Second, in both cases, the state specifies the arbitral procedures and chooses a panel of acceptable arbitrators. ${ }^{155}$

\section{Evaluating the Success of Insurance Arbitration}

Evaluating the success of consumer insurance arbitration requires a baseline view of the desirability of such arbitration. This is hardly a simple proposition. Numerous academics have debated the desirability of arbitration for consumers, and Congress has recently considered several bills that would curtail the use of predispute, mandatory arbitration provisions. ${ }^{156}$ Proponents of arbitration often claim that it has the virtues of increased speed and decreased cost, expert decision makers, and confidentiality. ${ }^{157}$ Critics counter that it tends to favor repeat players, suppress public information, produce suboptimal levels of precedent, have little impact in practice on costs or speed, and undermine class action lawsuits or punitive damages. ${ }^{158}$

152. See Del. CoDE ANN. tit. $18, \S 331$; id. tit. $21, \S 2118 ; 18-900-901$ Del. CoDE REGS. § 2 (3/1/2002).

153. See Haw. REv. STAT. § 431:10C-213; N.J. Stat. ANN. § 39:6A-5(i).

154. See Interview with Julia Moore, Arbitration Sec'y for the Del. Ins. Comm'r (Apr. $22,2008)$.

155. Three of the four no-fault states that require arbitration (New York, Minnesota, and New Jersey) have special procedures, administered through the American Arbitration Association or the National Arbitration Forum, which must be followed in no-fault arbitrations. BENDER, supra note $151, \S 15.30$. In each case, the parties must select arbitrators from a preapproved panel. See id. Similarly, the process of arbitration in Delaware is mandated by regulation. See 18-900-901 Del CODE REGS. $\S 2$. Arbitrators are volunteer attorneys who are paid a nominal amount and whose decisions records and awards are monitored by the department. See Interview with Julia M. Moore, supra note 154.

156. Arbitration Fairness Act of 2007, S. 1782, 110th Cong. (2007); H.R. 3010, 110th Cong. (2007). For a good summary of recent empirical literature on consumer arbitration, see Kirk D. Jensen, Summaries of Empirical Studies and Surveys Regarding How Individuals Fare in Arbitration, 60 CONSUMER FIN. L.Q. REv. 631 (2006).

157. See, e.g., Estreicher, supra note 4, at 564; Ware, supra note 4, at 89-93 (arguing that the efficiency of arbitration can ultimately benefit consumers).

158. Budnitz, supra note 4, at 133-34; Menkel-Meadow, supra note 4, at 38-57 (suggesting that arbitration may enhance the repeat-player advantage, but noting an absence of empirical evidence); Perschbacher \& Bassett, supra note 4, at 30 (focusing on the secrecy and lack of precedent in arbitration); Sternlight, supra note 4, at 1649 (arguing that firms design arbitration clauses to benefit themselves); Sternlight \& Jensen, supra note 4, at 77-92 (discussing how mandatory arbitration can eliminate class actions); W. Mark C. Weidemaier, 
The desirability of arbitration is no clearer in the specific context of insurance law. On one hand, there are legitimate reasons to think that concerns about arbitration may be enhanced when it comes to consumer insurance disputes. ${ }^{159}$ Consumer insurance arbitration may be unusually susceptible to biased decision making given the intensity of the "repeat player" problem in insurance and the malleability of insurance law. ${ }^{160}$ Moreover, the secrecy of most forms of consumer arbitration may be particularly unfavorable to long-run consumer interests because of the importance of reputation to the functioning of consumer insurance markets. ${ }^{161}$ However, arbitration may also offer distinctive potential benefits for insurance consumers. As described in Part I, the slow pace of litigation and its potential cost are particularly problematic for aggrieved insurance consumers. To the extent that arbitration allows policyholders to easily, cheaply, and quickly challenge their insurer's adverse coverage decision, it helps to offset these concerns. ${ }^{162}$ For related reasons, it may encourage settlement by lending credibility to plaintiffs' threats to challenge coverage decisions. $^{163}$

Weighing these competing costs and benefits of consumer arbitration is ultimately a subjective enterprise. ${ }^{164}$ Several commentators have consequently proposed shifting away from the familiar debate about arbitration's desirability relative to litigation and towards a discussion of the best way to improve current arbitration practices through targeted regulation. ${ }^{165}$ Unfortunately, such regulation is usually

Arbitration and the Individuation Critique, 49 ARIZ. L. REv. 69 (2007) (describing and critiquing the repeat-player advantage in arbitration).

159. See generally Randall, supra note 16, at 257-63; Public Citizen, supra note 148.

160. Abraham \& Montgomery, supra note 148, at 361-68; Randall, supra note 16, at 258-59.

161. On the importance of reputation in consumer insurance markets, see Schwarcz, supra note 15, at 1412-15. Not all forms of arbitration are secretive. For instance, securities and labor arbitration awards are published, and some employment arbitrations are also published. See generally Richard C. Reuben, Confidentiality in Arbitration: Beyond the Myth, 54 U. KAN. L. REv. 1255 (2006).

162. See Sykes, supra note 15 , at 422 (suggesting that mandatory arbitration in insurance contracts might be desirable because it could decrease the time insureds wait for recovery and thus reduce opportunism by insurers).

163. See Steven Shavell, Alternative Dispute Resolution: An Economic Analysis, $24 \mathrm{~J}$. LEGAL STUD. 1 (1995).

164. BRUNET ET AL., supra note 4, at 151 ("While some of the policy differences between critics and defenders are philosophical and theoretical, others rest on different impressions of the empirical world.").

165. A number of ADR scholars have proposed such regulation of arbitration. See, e.g., Paul Carrington, Regulating Dispute Resolution Provisions in Adhesion Contracts, 35 HaRV. J. ON Legis. 225 (1998); Amy Schmitz, Curing Consumer Warranty Woes Through 
stymied by the FAA and federal lawmakers' refusal to interfere with privately drafted arbitration provisions. ${ }^{166}$ But because states have unique authority to regulate insurance arbitration, this shift in focus is particularly appropriate in the insurance context. Thus, the relevant inquiry here is not whether arbitration of consumer insurance dispute is desirable. Rather, it is whether states have used their unique regulatory authority in the realm of insurance to harness the strengths of arbitration while limiting its weaknesses.

Judged by this metric, consumer insurance arbitration in the United States is, at most, only modestly successful. Most states have done little to promote insurance arbitration outside of the highly specific areas of property valuation and medical necessity disputes. For the vast majority of insurance coverage disputes, states have either largely ignored arbitration or have merely sought to ban mandatory arbitration terms. Regardless of which of these approaches is preferable, both fail to harness the potential benefits of arbitration while limiting its costs.

Where states have experimented with arbitration, they have designed schemes that are closely tied to the underlying dispute's subject matter and that, therefore, have limited application to other types of insurance disputes. First, both appraisal and external review attempt to limit the repeat-player problem of arbitration by using experts-such as automotive specialists, real estate appraisers, and doctors-to resolve factual disputes. Of course, experts often have divergent views that can implicate repeat-player problems. ${ }^{167}$ But experts are nonetheless viewed by many as being less susceptible to biased decision making than ordinary arbitrators because of their professional training and the "objectivity" of the underlying subject matter. ${ }^{168}$ At the very least, this veneer of objectivity helps mitigate the

Regulated Arbitration, 23 OHIO ST. J. ON DISP. RESOL. 627 (2008); Richard Speidel, Consumer Arbitration of Statutory Claims: Has Pre-Dispute [Mandatory] Arbitration Outlived Its Welcome?, 40 ARIZ. L. REV. 1069 (1998); Jeffrey W. Stempel, Keeping Arbitrations from Becoming Kangaroo Courts, 8 NEv. L.J. 251, 260-64 (2007).

166. Schmitz, supra note 165, at 629.

167. See, e.g., Hunter, supra note 132, at 156 (criticizing the ERO system because it "lacks sufficient mechanisms either to correct for possible bias or to enhance quality by review of the most difficult, and indeterminate, medical judgments"); cf. Murrill, supra note 100 , at 403 (expressing concerns about the advantages that mass disaster ADR programs may give to insurers).

168. See Hunter, supra note 132, at 101-21 (describing, and disputing, "the norm of deference to physician judgment," which is based on the notion that doctors have access to a "body of expert scientific knowledge"); Susan Stefan, Leaving Civil Rights to the "Experts": From Deference to Abdication Under the Professional Judgment Standand, 102 YALE L.J. 
perception that appraisal and external review unduly favor repeat players.

The expertise-driven subject matter of appraisal and external review may have other, nontransferable, benefits as well. For instance, regulations can require specific professional qualifications for expert decision makers, such as doctors and appraisers, whereas it would be difficult to craft such requirements for ordinary arbitrators. ${ }^{169}$ Although ordinary arbitrators are not state-approved, they typically are licensed, or otherwise regulated, in each of the consumer insurance arbitration schemes described above. ${ }^{170}$ Additionally, the relative insignificance of precedent in arbitration-which typically exacerbates insurers' repeat-player advantage ${ }^{171}$-may be less problematic in expertise-driven arbitrations such as appraisal and external review. In these types of cases, where disputes typically concern factual rather than legal issues, legal precedent tends to be of limited importance regardless of the procedure that is used to adjudicate the parties' rights. $^{172}$ Consequently, repeat players have less capacity to game the arbitral system by learning the decision-making tendencies of individual arbitrators.

Second, appraisal and external review both offer the prospect of genuinely faster and more accessible dispute resolution than litigation for reasons that are similarly tied to the underlying subject matter of the disputes. ${ }^{173}$ Both forms of ADR can be distinguished from "ordinary" arbitration because they are relatively informal, are paperbased, and incorporate elements of an inquisitorial, rather than

$639,655-62$ (1992) (describing the various ways in which law assumes that professionals are neutral, but disputing the validity of this view).

169. Most professions, including the medical profession and real estate appraisal profession, have clearly developed licensing standards.

170. See supra Part II.B.1 (describing licensing and monitoring of EROs, appraisers, arbitrators in no-fault states, and Delaware arbitrators). For a convincing argument that all arbitrators should be licensed and approved, see Stempel, supra note 165, at 260-64.

171. Abraham \& Montgomery, supra note 148, at 360 ("Because arbitrations are essentially confidential and set no precedents ... each arbitration is an island unto itself, not governed by any prior arbitration outcomes ...."). This may work to the benefit of insurers, who are better able than nonrepeat players to learn the patterns of specific arbitrators.

172. See id. This may be particularly true when it comes to factual disputes requiring expertise, because expert arbitrators employ decision-making criteria that are the output of their professions, rather than of precedent.

173. The potential benefits of a speedy and inexpensive forum may also be particularly significant in the appraisal and review contexts. In the health care context, coverage denials based on medical necessity determinations require fast decision making because they typically prevent patients from getting the treatment they seek. Similarly, valuation disputes tend to be too small in monetary value to allow policyholders to find representation on a contingency fee basis. 
adversarial, method. ${ }^{174}$ These design features are key reasons that appraisal and external review prove more accessible and efficient than litigation. Policyholders generally need not hire lawyers and the process proceeds much more quickly than ordinary arbitration. ${ }^{175}$ By contrast, there is some empirical evidence that the elaborate procedures of ordinary arbitration, along with its adversarial style, often render it no faster or more accessible than litigation. ${ }^{176}$

Unfortunately, informal procedures and inquisitorial inquiry are not likely to prove feasible in domains outside of external review and appraisal. In most disputes, adversarial presentation and elaborate procedural protections are necessary to ensure the fairness of the dispute resolution process. ${ }^{177}$ These safeguards can justifiably be limited in external review and appraisal only to the extent that one is convinced that the risk of biased decision making is muted in disputes, such as these, where experts decide factual questions. ${ }^{178}$ Regardless of how one evaluates that claim, it obviously has no purchase outside of the realms of appraisal and external review.

In sum, states have done little to harness the benefits and limit the costs of consumer arbitration in the domain of insurance, even though they have unique authority to do so. Where states have actively promoted consumer insurance arbitration, they have done so only where the risk of a repeat-player problem is perceived to be low and the prospect of increased accessibility is high. Although commendable, these efforts are consequently of limited use for crafting reform of consumer insurance arbitration more broadly.

174. See supra Part II.B.1 (describing informal and inquisitorial elements of external review and appraisal).

175. See supra text accompanying notes $127,142$.

176. See BRUNET ET AL., supra note 4, at 18 (noting little empirical evidence that arbitration guarantees a more efficient process than trial and suggesting that trials can be as efficient as arbitration according to some new evidence); Herbert $\mathrm{M}$. Kritzer \& Jill $\mathrm{K}$. Anderson, The Arbitration Alternative: A Comparative Analysis of Case Processing Time, Disposition Mode, and Cost in the American Arbitration Association and the Courts, 8 JUST. SYS. J. 6, 18 (1983) (finding that arbitration may, on average, take just as long as litigation due to the fact there exists less settlement in the arbitration context); Ware, supra note 4 , at 89-93.

177. See, e.g., Estreicher, supra note 4, at 567-68; Margaret M. Harding, The Limits of the Due Process Protocols, 19 OHIO ST. J. ON DISP. RESOL. 369, 387-89 (2004); Schmitz, supra note 165 , at 637 .

178. See Hunter, supra note 132, at 101-21; Stefan, supra note 168, at 655-62. 


\section{THE PRIVATE OMBUdSMAN MODEL FOR RESOLVING INSURANCE DISPUTES AND ITS AMERICAN COUNTERPARTS}

Given the states' poor track records for facilitating consumer insurance ADR, this Part looks beyond our own borders for direction. Of the many potential models, the British scheme for resolving consumer financial disputes, which is known as the Financial Ombudsman Service (FOS), ${ }^{179}$ is the most natural source of guidance. Indeed, "the United States and United Kingdom are often portrayed as fellow travelers in the world of financial regulation," given "their shared traditions of laissez-faire capitalism, common-law jurisprudence, self-regulatory organization[s], and disclosure-based securities regulation." 180 In the insurance realm, in particular, the United Kingdom has recently served as a model for would-be reformers of regulation. ${ }^{181}$ Moreover, the United Kingdom's insurance market is one of the few in the world that approaches the United States in size and complexity. ${ }^{182}$

The FOS traces its history to the early 1970 s, when the British consumer insurance industry was widely believed to be in a state of disrepair. ${ }^{183}$ In response, three British insurance companies voluntarily formed an independent "Insurance Ombudsman Bureau" (IOB) that

179. Few sources in American legal literature have discussed the FOS, but a number of academic sources from the United Kingdom and from international journals do focus on the FOS. See generally JAMES, supra note 6; Sharon Gilad, Accountability or Expectations Management? The Role of the Ombudsman in Financial Regulation, 30 LAW \& POL'Y 227 (2008); James \& Morris, supra note 8; Ian MacNeil, Consumer Dispute Resolution in the UK Financial Sector: The Experience of the Financial Ombudsman Service, LAW \& FIN. Markets Rev., Nov. 2007, at 515; Philip Rawlings \& Chris Willett, Ombudsman Schemes in the United Kingdom's Financial Sector: The Insurance Ombudsman, the Banking Ombudsman, and the Building Societies Ombudsman, 17 J. CONSUMER POL'Y 307 (1994); Yokoi-Arai, supra note 12.

180. Howell E. Jackson, An American Perspective on the U.K. Financial Services Authority: Politics, Goals \& Regulatory Intensity 2 (Harvard Law Sch., Discussion Paper No. 522, 2005), available at http://www.law.harvard.edu/programs/olin_center/papers/pdf/ Jackson_522.pdf.

181. See, e.g., Elizabeth F. Brown, E Pluribus Unum - Out of Many, One: Why the United States Needs a Single Financial Services Agency, 14 U. MIAMI BUS. L. REV. 1, 74-100 (2005); Elizabeth F. Brown, The Fatal Flaw of Proposals To Federalize Insurance 73-75 (Univ. of St. Thomas Sch. of Law, Working Paper No. 07-25, 2007), available at http://ssrn.com/ sol3/papers.cfm?abstract_id=1008993\#.

182. Whereas the American insurance market is the largest in the world, accounting for thirty-one percent of worldwide premium income, Britain's market is the third largest in the world (behind Japan), accounting for eleven percent of worldwide premium income. See ASS'N OF BRITISH INSURERS, UK INSURANCE-KEY FACTS 3 (2007), available at http://www.abi.org.uk/BookShop/ResearchReports/UK\%20Insurance\%20-

$\% 20 \mathrm{Key} \% 20 \mathrm{Facts} \% 202007$.pdf.

183. See Tyldesley \& Paruk, supra note 9. 
had many of the same basic features as the current FOS. ${ }^{184}$ The IOB investigated consumers' complaints and, when appropriate, ordered member insurers to pay up to $£ 100,000$ to the consumer. ${ }^{185}$ Consumers who were not pleased with the IOB's decision were free to sue in court. ${ }^{186}$ The IOB expanded quickly, with virtually all insurers joining it within a few years. ${ }^{187}$ In the next two decades, seven other British industries developed their own "private ombudsman" schemes based on the insurance industry model. ${ }^{188}$ By 2000, the British Parliament formally joined the IOB with its peer consumer financial ombudsman organizations to form the FOS. ${ }^{189}$ Today, the FOS employs approximately 825 people and works with a budget of approximately $£ 50$ million. $^{190}$ Its jurisdiction extends to virtually all consumer financial services, including insurance, banking, and investment. ${ }^{191}$ In recent years, seventeen to twenty-two percent of its total caseload has involved complaints about insurance.

This Part compares the FOS with its American counterparts. Subpart A describes the FOS in detail, comparing it to consumer insurance ADR in the United States. Subpart B then argues that many of the FOS's constitutive elements mirror consumer insurance ADR in the United States. It concludes with a puzzle that is the subject of Part IV: how can it be that the FOS is so much more successful than its American counterparts when many of its basic features seem to resemble the American system?

\section{A. The FOS's Process of Dispute Resolution}

The FOS can be understood to utilize four stages of dispute resolution: (1) internal complaint procedures, (2) a frontline call

184. Id.

9.

185. See Rawlings \& Willett, supra note 179, at 311-17; Tyldesley \& Paruk, supra note

186. See Rawlings \& Willett, supra note 179, at 311-17; Tyldesley \& Paruk, supra note 9.

187. See Sharon Gilad, Exchange Without Capture: The UK Financial Ombudsman Service's Struggle for Accepted Domain, 86 PUB. ADMIN. 907, 910-11 (2008); Rawlings \& Willett, supra note 179 , at 311 .

188. James \& Morris, supra note 8, at 167.

189. Id. at 172 .

190. Fin. Ombudsman Serv., AnNual Review 2007/08, at 49 (2008), http://www. financial-ombudsman.org.uk/publications/ar08/ar08.pdf [hereinafter ANNUAL REVIEW '08]. Case fees, discussed infra Part IV.A.2, supply the FOS with about sixty-four percent of its funding, with the remainder coming from a general tax on the industry. See ANNUAL REVIEW '08, supra, at 50.

191. ANNUAL REVIEW'08, supra note 190, at 64.

192. Id. at 18 . 
office, (3) adjudicator conciliation, and (4) ombudsman review. This Part describes these four stages, emphasizing how each one resembles an element of American consumer insurance ADR.

\section{Stage One: Internal Complaints}

Before consumers can complain to the FOS, they must first lodge a grievance with their insurer and provide it with eight weeks to address the complaint. ${ }^{193}$ This echoes, and formalizes, the recommendations of many state insurance regulators that consumers first contact their insurer before lodging a complaint. ${ }^{194}$ Similarly, as in most American states, British insurers must maintain their own internal complaint handling procedures. ${ }^{195}$ But British firms are required not simply to keep track of basic data about internal complaints but also to investigate those complaints and to respond to them in writing within eight weeks. ${ }^{196}$ All such responses must inform policyholders of their right to refer the case to the FOS and must also contain a separate pamphlet, written by the FOS, about the FOS process. ${ }^{197}$ Internal complaint handling in the United Kingdom, therefore, more closely resembles the robust American rules governing internal complaints in health insurance than the more general American internal review rules for insurers. ${ }^{198}$ Additionally, whereas most American states define a complaint only to include written expressions of grievances, the British definition encompasses oral expressions of dissatisfaction as well. ${ }^{199}$

193. Fin. Servis. Auth. (FSA), Dispute Resolution: Complaints $\$ 1.6 .2(2008)$, available at $\mathrm{http}: / /$ ssahandbook.info/FSA/html/handbook/DISP [hereinafter FSA HANDBOOK].

194. See supra text accompanying note 71 .

195. See generally AdAM SAMUEL, CONSUMER COMPLAINTS AND COMPENSATION: A GUIDE FOR THE FINANCIAL SERVICES MARKET (2005) (comprehensively reviewing the internal complaint-handling rules for consumer financial services firms); Adam Samuel, Consumer Financial Services in Britain: New Approaches to Dispute Resolution and Avoidance, 3 EUR. BuS. ORG. L. REv. 649, 674-77 (2002) (describing internal complaint-handling rules).

196. See FSA HANDBOOK, supra note 193, § 1.6.2; Samuel, supra note 195, at 676.

197. See FSA HANDBOOK, supra note $193, \S 1.6 .2$. These rules are intended to ensure "[e]ffective and transparent procedures for the reasonable and prompt handling of complaints." Id. \$1.3.1 (emphasis in original); Samuel, supra note 195, at 676.

198. Compare supra text accompanying notes 73-75 with supra text accompanying notes $138-141$.

199. FSA HANDBOOK, supra note 193, glossary C (defining a complaint as "any oral or written expression of dissatisfaction, whether justified or not . . . about the provision of, or failure to provide, a financial service"). 


\section{Stage Two: The Frontline Call Center}

All complaints to the FOS are initially routed to a call center, which is roughly analogous to the branches of state insurance offices that answer incoming consumer calls. ${ }^{200}$ As with state regulators, the services of the FOS are available to consumers free of charge. ${ }^{201}$ FOS call center employees perform many of the same duties as state regulators, ensuring that the consumer has lodged an internal complaint, that the complaint is within the FOS's jurisdiction, and that the grievance is timely. ${ }^{202}$ Call center employees also mirror state regulators in their initial treatment of a call: like American regulators, they first determine whether the call is merely an inquiry or a complaint and assess the FOS's jurisdiction over the complaint. ${ }^{203}$

There are at least two differences between the FOS call center and American regulators' processes for initially processing consumer complaints. First, call center employees contact the consumer's insurer and ask it to forward its response to the consumer from stage one, the internal complaint handling process. ${ }^{204}$ Second, once a call center employee designates a consumer complaint as an official "case," the firm is required to pay a $£ 450$ (\$675) fee, regardless of the case's subsequent trajectory. ${ }^{205}$ Call center employees often attempt to resolve relatively straight-forward complaints with a firm quickly, before the matter is designated as a case and the firm is charged.

\section{Stage Three: Adjudicator Conciliation}

Once the call center elevates a complaint to an official "case," it is routed to an "adjudicator."207 Adjudicators are quite similar to the "complaint investigators" in state regulators' offices: they are drawn

200. See ANNUAL REVIEW '08, supra note 190, at 12-14; supra text accompanying notes $77-84$.

201. See Key Facts About the Financial Ombudsman Service, http://www.financial ombudsman.org.uk/publications/ar08/index.html\#al (last visited Feb. 13, 2009).

202. See id. at 12-14.

203. Id. at 13-14.

204. See James \& Morris, supra note 8, at 179-80; Samuel, supra note 195.

205. See ANNUAL REVIEW '08, supra note 190, at 49, 66; Fin. Ombudsman Serv., A Quick Guide To Funding and Case Fees, http://www.financial-ombudsman.org.uk/ publications/technical_notes/QG1.pdf (last visited Nov. 24, 2008). Firms need not pay the case fee if the case is one of the first two cases of the year involving their firm. See ANNUAL REVIEW '08, supra note 190. This fee structure is intended to reduce the case fee's impact on small firms. Fin. Ombudsman Serv., Consultation Paper ch. 6 (June 2006), http://www. financial-ombudsman.org.uk/publications/technical_notes/consumer_credit/6.htm.

206. ANNUAL REVIEW '08, supra note 187, at 12-14.

207. Id. at 14-15. 
from a wide variety of backgrounds, including from inside the industry, from legal practice, from public interest organizations, and from dispute resolution backgrounds. ${ }^{208}$ They investigate the consumer's complaint by collecting and examining relevant documents. ${ }^{209}$ Adjudicators' investigations are "inquisitorial" in the sense that they are not limited by the specific claims that complainants articulate. $^{210}$ As with regulatory complaint investigators, adjudicators have no legal authority to issue binding decisions on individual disputes. $^{211}$ Adjudicators nonetheless attempt to encourage settlements between consumers and insurers that are consistent with their view of the case, using a process that the FOS terms "guided conciliation."212

Despite the many similarities in the roles of FOS adjudicators and state complaint investigators, there are several important distinctions as well. First, unlike state regulators, adjudicators' evaluations of cases in the course of guided conciliation focus heavily on the insurer's internal complaint file. $^{213}$ Recall that the insurer prepares this file before the consumer ever complains to the FOS. By contrast, in most states, insurers' internal complaint files do not contain any analysis of the complaint, and complaint investigators rely principally on the insurer's prepared response to the investigator. ${ }^{214}$

208. See Interview with Melissa Collett, Ombudsman, Fin. Ombudsman Serv. (Jan. 8 $\& 9,2008)$.

209. See id.

210. See Walter Merricks, A Quarter-Century of Ombudsmen, OMBUDSMAN NEws, Apr. 2006, at 1, available at http://www.financial-ombudsman.org.uk/publications/ ombudsman-news $/ 52 / 52$.htm (stating that a fundamental principle of the FOS is that "the ombudsman should operate on an inquisitorial rather than an adversarial basis").

211. See AnNUAL ReVIEW '08, supra note 190, at 43.

212. See id:; Walter Merricks, Chief Ombudsman's Report, http://www.financialombudsman.org.uk/ar03/ar03-chief.htm (last visited Nov. 16, 2008). Of course, the details of how "guided conciliation" operates depend on the individual adjudicator. In general, the adjudicator will often first contact the party whom he or she believes has the nonmeritorious claim and determine that party's willingness to accept that conclusion. See James \& Morris, supra note 8 , at $179-80$. In cases of resistance, the adjudicator may take more formal measures to conciliate a resolution, often writing an adjudicator's report that lays out his or her views of the proper resolution and sending it to both parties. See id. In broad terms, then, this process of guided conciliation resembles the process of conciliation or evaluative mediation that state regulators deploy in response to consumer complaints. See supra note 90 and accompanying text.

213. See SAMUEL, supra note 195; Walter Merricks, Chief Ombudsman, Fin. Ombudsman Serv., Speech at the Financial Services Authority as Part of the Canary Wharf Lecture Series: Is the Ombudsman Fair and Reasonable? (Oct. 28, 2004) [hereinafter Merricks Speech] (explaining that the FOS "resolves disputes by examining written materials submitted to us" and the "firm should send us the fruits of its own investigations, with its files and the reason it rejected the complaint").

214. See supra text accompanying notes $83-84$. 
Second, unlike complaint investigators in the United States, FOS adjudicators focus solely on resolving consumer complaints and have no regulatory authority. The FOS is formally independent from the British insurance regulator, the Financial Services Authority (FSA). ${ }^{215}$ As the FOS has put it: "[w]e make decisions on one-off individual cases ... we do not carry out regulatory functions." 216 Of course, these dividing lines are far from crisp, and the FSA and FOS must consequently coordinate with one another and share information and resources. $^{217}$ For instance, the FOS provides the FSA with its data, which the FSA uses to help guide its market-conduct analysis. ${ }^{218}$ The FOS also makes firm-specific outcome data publicly available, as do American insurance regulators. ${ }^{219}$ Similarly, when adjudicators encounter potential regulatory issues, they can formally refer them to the FSA for investigation. ${ }^{220}$ Not only does the FOS assist the FSA in its regulatory function, but the FSA also assists the FOS in dealing with cases that have "wider implications" for the industry.

215. See James \& Morris, supra note 8 , at $173-74$. The FSA regulates all financial services in the United Kingdom, including insurance. See Memorandum of Understanding Between the Financial Services Authority (the FSA) and the Financial Ombudsman Service (the FOS) (Apr. 6, 2007), http://www.fsa.gov.uk/pubs/mou/fsafos.pdf [hereinafter Memorandum of Understanding]. While the FOS is primarily retrospective in its orientation, focusing on resolving individual disputes that have already occurred, the FSA is primarily prospective in its outlook, focusing on issues such as market stability, conduct, and structure. See id; ANNUAL REVIEW '08, supra note 190, at 42-45. However, the FSA does retain some control over the FOS. For instance, it approves its budget and nominates some of its board members. See James \& Morris, supra note 8, at 173-74.

216. See Fin. Ombudsman Serv., Annual Review and Report \& Financial STATEMENTS: 1 APRIL 2005 TO 31 MARCH 2006, at 7 (2006), http://www.financialombudsman.org.uk/publications/ar06/ar06-chair.htm.

217. See generally Gilad, supra note 187, at 914-17 (exploring the practical difficulties that the FOS encounters in attempting to confine its role to dispute resolution rather than regulation).

218. See Memorandum of Understanding, supra note 215.

219. Until recently, this data was not made public. This lack of transparency was criticized in a recent independent review of the FOS. See Fin. Ombudsman Serv., Ombudsman Welcomes Lord Hunt's Report on "Opening Up, Reaching Out and Aiming High" (Apr. 9, 2008), http://www.financial-ombudsman.org.uk/news/updates/Lordhunt_ Report.html. In response, the FOS announced that it would change its practice and make this firm-specific data publicly available. See Fin. Ombudsman Serv., Policy Statement: Our Strategic Approach to Transparency 38-39 (July 2008), http://www.financial-ombudsman. org.uk/publications/policy-statements/transparency.html.

220. See Memorandum of Understanding, supra note 215.

221. The details of this exchange are described at a dedicated Web site, http://www. wider-implications.info, which the FOS and FSA jointly maintain. Under the Wider Implications process, any interested party, including the FOS, the firm, or the FSA, can argue that a particular case at the FOS, or issue that the FOS deals with, involves wider implications. Wider Implications, How Can a Wider-Implications Issue Be Raised?, http://www.wider-implications.info/process/raising_wi.htm (last visited Feb. 10, 2009). The 
Finally, unlike American regulators, who have no formal criteria for determining how complaints that do not raise regulatory issues ought to be resolved, adjudicators evaluate complaints in the course of guided conciliation based on a "fair and reasonable" standard. ${ }^{222}$ This standard is defined by statute and requires the FOS to take into account the "relevant law, regulations, regulators' rules and guidance, relevant codes of practice and, where appropriate, what [the FOS] considers to have been good industry practice at the relevant time., ${ }^{, 223}$ Adjudicators' primary source of guidance in applying this standard is previous ombudsman decisions (described below). ${ }^{224}$ These ombudsman decisions and the specific subrules of the fair and reasonable standard that they establish are available to adjudicators through an extensive set of online materials, including a knowledge tool kit that provides detailed information on various types of cases with links to relevant ombudsman decisions. ${ }^{225}$ While these materials are not "binding" on adjudicators, they substantially influence adjudicators' guided conciliation efforts. ${ }^{226}$ As a result, while the fair and reasonable standard is clearly broad and flexible, it is often quite specific in practice for adjudicators. ${ }^{227}$

relevant criteria for assessing whether to invoke this process includes whether it affects a large number of consumers or businesses, the financial integrity of a business, interpretation of FSA rules, or a common practice by businesses. Wider Implications, What Is a Wider Implications Issue?, http://www.wider-implications.info/process/what_is_within (last visited Feb. 10, 2009). When a case is deemed to involve wider implications, the FOS has discretion to develop a consistent approach to relevant cases while the FSA addresses the issue. Wider Implications, What Will the FSA, OFT and Ombudsman Service Do?, http://www.widerimplications.info/process/what_will_be_done.htm\#2a (last visited Feb. 10, 2009).

222. See James \& Morris, supra note 8, at 184-88.

223. FSA HANDBOOK, supra note $193, \S 3.6 .4$. The Financial Services and Markets Act, 2000 , c. $8, \S 228$ (2) (Eng.), provides that a complaint must be assessed according "to what is, in the opinion of the ombudsman, fair and reasonable in all the circumstances of the case."

224. See Interview with Simon Coe, Head of Casework Div., Fin. Ombudsman Serv. (Jan. 9, 2008).

225. MacNeil, supra note 179 , at 520 (describing "internal FOS procedures" that help to ensure consistency "though training, mentoring, and access to relevant source materials").

226. See Gilad, supra note 179 , at $241-42$.

227. Sec, e.g., Letter from Nigel Pope, Adjudicator, Fin. Ombudsman Serv., to Teresa Fritz (Dec. 8, 2006) (on file with author) (describing the specific procedure for handling Mortgage Endowment complaints and noting where it is available online). As Rawlings and Willett describe, this basic principle has been employed to form more specific precedents. See Rawlings \& Willett, supra note 179, at 312-14. For instance, insurers are liable for misstatements by their agents and are responsible for asking for material information. See id. Much like certain versions of the reasonable expectations doctrine, the fair and reasonable standard thus serves as a broad goal upon which more specific, and rule-like, doctrines are constructed. See Kenneth S. Abraham, The Expectations Principle as a Regulative Ideal, 5 CONN. INS. L.J. 59, 61-62 (1998); Schwarcz, supra note 14, at 1427-30. Indeed, Rawlings and 
Adjudicator evaluations of a case, which are frequently generated in the course of guided conciliations, generally describe the background facts, reference relevant rules or procedures, and justify the adjudicator's view based on factors such as policy language, industry standards, and the consumer's reasonable expectations. ${ }^{228}$ All factual disputes are resolved based on "the balance of probability" in light of the available evidence. ${ }^{229}$ Importantly, adjudicators do not merely attempt to convince parties to accept their written evaluation of a case: their efforts to conciliate settlements are much more fluid, and often involve phone conversations, initial letters setting out their preliminary view of a case, and efforts to convince either party to accept various concessions. ${ }^{230}$

\section{Stage Four: Ombudsman Review}

If either party is unwilling to settle a case voluntarily through guided conciliation at the adjudicator stage, then the matter proceeds to ombudsman review. Ombudsman review strongly resembles appraisal and external review, the prominent forms of state-facilitated arbitration in the United States. ${ }^{231}$ Most notably, each of the six insurance ombudsmen is legally empowered to bind insurers to pay consumers up to $£ 100,000$. $^{232}$ As in both external review and most versions of appraisal, consumers can choose whether to use the ADR process or sue in court after the dispute arises. ${ }^{233}$ Finally, like external review and appraisal (as well as the earlier adjudicator stage), ombudsman evaluations of a case are essentially inquisitorial rather than adversarial. ${ }^{234}$

As with the other FOS stages, however, the ombudsman review stage is distinctive from American versions of consumer insurance

Willett describe the fair and reasonable standard as a way of ensuring that the outcome should match the "responsibility which the consumer - with no knowledge of insurance law — might reasonably anticipate the insurer would bear." See Rawlings \& Willett, supra note 179, at 313.

228. See, e.g., Letter from Nigel Pope, supra note 227.

229. See Fin. Ombudsman Serv., A Quick Guide to How We Handle Disputes Between Businesses and Consumers (Aug. 2008), http://www.financial-ombudsman.org.uk/ publications/technical_notes/QG7.pdf.

230. See generally ANNUAL REVIEW '08, supra note 190, at 42; Gilad, supra note 179, at 234-55; Interview with Ray Neighbour, Serv. Review Manager, Fin. Ombudsman Serv. (July 15, 2008).

231. See supra Part II.B.

232. See James \& Morris, supra note 8, at 189. Insurers enjoy a limited right of appeal to the courts when an ombudsman rules against them. See id. at 175.

233. See id.

234. See Merricks, supra note 210. 
arbitration in several important respects. ${ }^{235}$ First, ombudsmen's authority is asymmetric: ombudsmen are only empowered to bind insurers, not consumers. ${ }^{236}$ In other words, consumers are free to sue their insurers for coverage regardless of the outcome of FOS review, whereas insurers are bound to adhere to an ombudsman decision. However, adverse ombudsman decisions are admissible in court against a consumer. ${ }^{237}$

Second, ombudsmen are public, high-ranking officials, whereas American arbitrators are private contractors. ${ }^{238}$ In that sense, ombudsmen are closer to administrative law judges than to arbitrators, even though they resolve disputes between private parties, rather than between individuals and the government. Unlike either administrative law judges or arbitrators, ombudsmen not only decide cases, but they also help to administer the FOS. In the latter capacity, they help train and monitor adjudicators, develop strategic plans for the FOS, and create policy for the organization. ${ }^{239}$

Third, ombudsmen base their decisions in individual cases predominantly on the paper materials that FOS adjudicators and call center employees compiled at earlier stages of the process. This record includes all papers relating to the case, such as the adjudicator's analysis, the internal complaint, and any documents generated during the conciliation process. ${ }^{240}$ Consequently, unlike any version of American arbitration, ombudsmen have full access to earlier efforts to conciliate a solution to the parties' dispute. ${ }^{241}$

235. Like adjudicators, ombudsmen do not perform a regulatory role and only refer matters to the FSA as a secondary portion of their job. See Memorandum of Understanding, supra note 215 . This, however, is not a distinction between the ombudsman review stage and arbitration, which is also nonregulatory in orientation.

236. See Merricks, supra note 210 , at 1.

237. Merricks Speech, supra note 213 ("[C]ourts are off-putting enough to most consumers-even if they do not have a reasoned rejection from the ombudsman of their complaint-that the judge would certainly see."); see, e.g., Tonkin v. U.K. Ins. Ltd., [2006] EWHC (QB (TCC)) 1120, [134]-[145] (summarizing and adopting as a "sensible" conclusion an adjudicator's decision, after the insured chose not to accept the adjudicator's decision at the FOS and sued in court).

238. See James \& Morris, supra note 8 , at $174-75$. The process by which ombudsmen are selected (discussion of which is beyond the scope of this Article) is described in James \& Morris. See id.

239. See Fin. Ombudsman Serv., A Quick Guide to the Role and Work of Our Panel of Ombudsmen (Nov. 2007), http://www.financial-ombudsman.org.uk/publications/technical_ notes/QG-ombudsman-panel.pdf; see also Gilad, supra note 179, at 241-42.

240. See Interview with Melissa Collett, supra note 208.

241. See id. By contrast, a fundamental tenet of mediation in most American contexts is that it is secretive, especially with respect to subsequent decision makers. See Reuben, supra note 161 , at 1280 . 
Finally, like adjudicators, ombudsmen employ a "fair and reasonable" standard in evaluating cases and writing their decisions. Although this standard does not require ombudsmen to adhere to the law when doing so would not serve justice, there are only a limited number of domains in which ombudsmen affirmatively depart from legal principles. ${ }^{242}$ When doing so, ombudsmen must correctly explain the law and their rationale for departing from it. ${ }^{243}$ As such, "[w]hile the fair and reasonable standard offers a potentially wide choice to the Ombudsman in making a decision, it will be difficult to disregard the law or regulatory rules which clearly 'bite' in the specific circumstances." ${ }^{244}$ Similarly, while the fair and reasonable standard does not explicitly require ombudsmen to adhere to prior decisions, ombudsmen effectively treat prior decisions as precedent that is entitled to significant deference in resolving cases. ${ }^{245}$ Ombudsman decisions resolve factual disputes based "on the balance of probabilities" 246 and are subject to narrow judicial review to determine whether they contain legal or procedural errors or are "perverse and irrational."247 In a limited number of cases-including insurers' allegations of consumer fraud and cases that raise difficult and novel

242. See Rawlings \& Willett, supra note 179, at 312-14; Insurance Contract Law: Misrepresentation, Non-Disclosure and Breach of Warranty by the Insured 70 (The Law Comm'n, Consultation Paper No. 182 \& The Scottish Law Comm'n, Discussion Paper No. 134, 2007), available at http://www.lawcom.gov.uk/docs/cp182_web.pdf [hereinafter Insurance Contract Law]. The most notable examples where the FOS affirmatively departs from the law involve nondisclosure and misrepresentation. See Insurance Contract Law, supra, at 65-66 (describing ways in which FOS departs from law). These departures are longstanding and reflect a near-consensus among British legal experts that certain substantive areas of insurance law are unreasonably harsh when applied in the consumer sphere. See id. at 71 .

243. See R. in re Heather Moor \& Edgecomb Ltd. v. Fin. Ombudsman Serv., [2008] EWCA (Civ.) 642, [35], [49] ("[An ombudsman] is free to depart from the relevant law, but if he does so he should say so in his decision and explain why.").

244. MacNeil, supra note 189, at 520.

245. Id.

246. See, e.g., Letter from Heather Clayton, Lead Ombudsman, Fin. Ombudsman Serv., to Teresa Fritz, Which? (Apr. 25, 2007) (on file with author).

247. See R. in re IFG Fin. Serv. Ltd. v. Fin. Ombudsman Serv. Ltd. [2005] EWHC (Admin.) 1153, [13] ("[I]f [an ombudsman's] opinion as to what is fair and reasonable in all the circumstances of the case is perverse or irrational, that opinion, and any determination made pursuant to it, is liable to be set aside on conventional judicial review grounds.") (emphasis added)); R. in re Kenneth Green \& Co. v. Fin. Ombudsman Serv., Ltd., [2003] EWHC 338 (Admin.), [60] ("The [reviewing] court cannot quash a decision of an [ombudsman] merely because it considers that a finding of fact by the [ombudsman] was incorrect, or because ... the Court would have made a different assessment of the respective merits ...."). 
legal questions - an ombudsman may decline to consider the merits of a dispute because it is best suited for judicial resolution. ${ }^{248}$

In practice, ombudsman decisions resemble adjudicators' "views" and "evaluations" of the case that are generated during guided conciliation. $^{249}$ In part, this is because, as described earlier, adjudicators use ombudsman decisions when they are attempting to resolve cases. ${ }^{250}$ However, ombudsman decisions do tend to be more legalistic than the materials produced by adjudicators in guided conciliation, as most ombudsmen have some legal training. ${ }^{251}$ Ombudsman decisions are sent to both parties, and abbreviated, anonymous versions are published in a regular publication called "Ombudsman News.",252

\section{B. Comparing the American and British Approaches \\ 1. The Similar Elements of Consumer Insurance ADR in the United Kingdom and the United States}

Although there are significant distinctions between the British and American ADR schemes, their basic components are quite similar. In both systems, publicly facilitated ADR is comprised of four basic elements: (1) consumer complaints to insurers (internal complaints), (2) initial complaint handling by a call center, (3) longer-term conciliation, and (4) some version of arbitration. These stages are diagrammed below. In the United Kingdom, these stages are unified within a single umbrella organization, whereas they are more dispersed

248. See FSA HANDBOOK, supra note $193, \S 3.3 .4$. There are numerous reasons that the FOS can dismiss a complaint without consideration of the merits, including the belief that the matter involves (1) a claim of fraud (which is hard to adjudicate on paper), (2) a novel legal issue, (3) a reasonable application of commercial judgment, or (4) no material loss. See id. $\S 3.3 .4$.

249. See, e.g., Letter from Heather Clayton, supra note 246; Letter from Melissa Collett, Ombudsman, Fin. Ombudsman Serv., to Mrs. Cadd (Mar. 2, 2007) (on file with author); Letter from Sue Wrigley, Ombudsman, Fin. Ombudsman Serv., to Anonymous (Aug. 16,2007 ) (on file with author).

250. See Interview with Melissa Collett, supra note 208.

251. See JAMES, supra note 6, at 209 (describing "the dominance of the legal profession amongst those appointed to the post of ombudsman").

252. See id; see, e.g., Fin. Ombudsman Serv., Ombudsman News, http://www. financial-ombudsman.org.uk/publications/ombudsman.htm (last visited Nov. 16, 2008) (posting latest ombudsman news and describing various cases that the FOS resolved). Prior to 1991, the IOB annual reports articulated general principles to serve as guidance to the insurance community. See Gilad, supra note 187, at 912-14. This created some tensions, because it appeared to move the IOB closer to being a regulator than a body for resolving consumer disputes. See id. In response, the IOB moved to simply publishing anonymous summaries of cases. See id. 
within the United States. Indeed, arbitration in the United States is unrelated to the other three ADR processes and is only available for a small subset of issues. These distinctions resurface later, but for now, the basic point is that each of the FOS's constituent elements has a direct analog in most American state systems.

\section{ADR Structure (Figure A)}

\begin{tabular}{|l|l|}
\hline \multicolumn{1}{|c|}{ FOS } & American Consumer Insurance ADR \\
\hline $\begin{array}{l}\text { Internal complaints prerequisite to } \\
\text { FOS review }\end{array}$ & $\begin{array}{l}\text { Internal complaints suggested prior to } \\
\text { regulator review; required prior to } \\
\text { external review }\end{array}$ \\
\hline Call center receives complaint & $\begin{array}{l}\text { Regulator's call center receives } \\
\text { complaint }\end{array}$ \\
\hline $\begin{array}{l}\text { Adjudicators engage in guided } \\
\text { conciliation to resolve case }\end{array}$ & $\begin{array}{l}\text { Complaint handlers attempt to } \\
\text { conciliate resolution of case }\end{array}$ \\
\hline $\begin{array}{l}\text { Review by ombudsmen, who are } \\
\text { public employees }\end{array}$ & $\begin{array}{l}\text { Appraisal/external review by private } \\
\text { individuals }\end{array}$ \\
\hline
\end{tabular}

Not only are the basic elements of the FOS and American schemes similar, but so too are a number of other features of the ADR process, which are summarized graphically in Figure B. First, both the FOS and many American schemes allow consumers to wait until after a dispute arises before choosing between the available ADR options and litigation. In the United States, such ex post consumer opt out is common in both external review and appraisal as well as other consumer insurance arbitration schemes, such as those involving nofault and Delaware's arbitration program. ${ }^{253}$ It is also a centerpiece of the Interstate Insurance Compact, as well as recently proposed federal legislation on consumer arbitration provisions. ${ }^{254}$ This structure serves as a consumer safeguard, ensuring that consumers will not be made worse off by the ADR process than they are without it. ${ }^{255}$

253. See supra Part II.B.

254. See Arbitration Fairness Act of 2007, S. 1782, 110th Cong. (2007); Interstate Insurance Product Regulation Commission Web Site, supra note 146.

255. Many American academics have endorsed this proposal. See BRUNET ET AL., supra note 4, at 182-83. Unlike consumers, insurers cannot opt out after a dispute arises in any of these schemes. This makes sense: not only would such an opt out undermine any authority of the ADR mechanism, but insurers are less in need of such protection, as ADR generally poses less risk for repeat players. Some have argued against postdispute consumer opt out, observing that consumers who have strong cases will choose not to pursue arbitration. See Estreicher, supra note 4, at 567-68. This may be less of a problem in the insurance context, given the significant discount rate of policyholders and their risk aversion. See supra Part I.B. Moreover, this result would be no worse than the status quo. 
Second, in each ADR mechanism, the process is inquisitorial and relatively informal. Recall that, like the FOS, both regulator-provided conciliation and the two forms of state-facilitated insurance arbitration are fundamentally inquisitorial, with a neutral third-party free to look beyond the parties' arguments in scrutinizing the merits of the dispute. $^{256}$ As stated above, this structure is a crucial feature in making ADR truly accessible to uninformed consumers, who generally will have little sense of how to frame or substantiate their complaints. ${ }^{257}$

Finally, both the FOS and most American consumer insurance ADR mechanisms are free, or quite inexpensive, for consumers and are predominantly funded by insurers. ${ }^{258}$ In many ways, the $£ 450$ case fee that British insurers pay to the FOS is comparable to the costs that insurers face when a consumer invokes external review: in both cases, the insurer directly funds the ADR process regardless of the ultimate outcome of the dispute. This once again significantly increases the accessibility of insurance ADR, especially given that aggrieved insurance consumers tend to be resource-constrained. ${ }^{259}$

Other ADR Features (Figure B)

\begin{tabular}{|l|l|l|}
\hline \multicolumn{1}{|c|}{ FOS } & \multicolumn{1}{|c|}{$\begin{array}{c}\text { American Regulatory } \\
\text { Conciliation }\end{array}$} & \multicolumn{1}{|c|}{$\begin{array}{c}\text { American Insurance } \\
\text { Arbitration }\end{array}$} \\
\hline $\begin{array}{l}\text { Ex post consumer opt } \\
\text { out }\end{array}$ & Ex post consumer opt out & $\begin{array}{l}\text { Ex post consumer opt } \\
\text { out (common in } \\
\text { external review and } \\
\text { appraisal) }\end{array}$ \\
\hline Service is free & Service is free & $\begin{array}{l}\text { Fees are split } \\
\text { (appraisal) or } \\
\text { arbitration is free } \\
\text { (external review) }\end{array}$ \\
\hline $\begin{array}{l}\text { Inquisitorial, paper- } \\
\text { based process }\end{array}$ & $\begin{array}{l}\text { Inquisitorial, paper-based } \\
\text { process }\end{array}$ & $\begin{array}{l}\text { Inquisitorial, paper- } \\
\text { based process }\end{array}$ \\
\hline
\end{tabular}

While there are also some striking distinctions between the FOS and American consumer-insurance ADR, even these are less significant than they initially appear. Most notably, the asymmetric

256. See supra Part II.

257. See Interview with Walter Merricks, Chief Ombudsman, Fin. Ombudsman Serv. (Jan. 8, 2008); supra text accompanying notes 174-177.

258. Regulatory complaint handling is free for consumers in all states, and the same is generally true of external review. However, consumers must generally pay the costs of their own appointed appraiser in appraisal. See supra text accompanying notes 128, 141.

259. See supra Part I.B. 
authority of the FOS-which allows policyholders to litigate a case even if an ombudsman rules against them ${ }^{260}$-is perhaps the most "radical" element of the FOS process for Americans. This consumer protection device is designed to ensure consumers that they will not lose anything by seeking FOS review. But in practice, this protection is largely illusory, as consumers virtually never invoke their "litigation option., ${ }^{261}$ There are a variety of reasons for this fact. First, punitive damages are much less common in the United Kingdom than in the United States and have historically been unavailable in breach of contract cases, including insurance claims disputes. ${ }^{262}$ Consequently, it is difficult to find British attorneys who will take an insurance coverage case on a contingency fee basis. Second, Britain's loser-pays fee-shifting rule enhances the riskiness of litigation for consumers. ${ }^{263}$ Third, the British courts have historically been quite anticonsumer in insurance contexts. ${ }^{264}$ Finally, and most significantly, consumers' supposed right to litigate even if an ombudsman rules against them is significantly undermined by the fact that an ombudsman's adverse decision is generally admissible in court against a consumer. ${ }^{265}$

\section{The Different Results of Consumer Insurance ADR in the United Kingdom and the United States}

The individual pieces of the FOS process, therefore, resemble our own internal complaint, conciliation, and arbitration procedures for consumer insurance disputes. This Subpart shows that, despite these similarities, the FOS has enjoyed far greater success than the American ADR schemes. In fact, the FOS performs remarkably well along each of the dimensions in which American ADR schemes falter.

First, the FOS has had dramatically more success than American regulators in quickly conciliating voluntary resolutions to insurance disputes. Recall that, as a rough approximation, American regulators

260. See supra text accompanying note 236.

261. Merricks Speech, supra note 213 ("Few commentators suggest that consumers should be bound by the ombudsman - perhaps for the reason that very few of the consumers whose cases we reject then exercise their right to take their dispute to court."). But cf. Merricks, supra note 210 , at 1 (stating that a fundamental principle of the FOS is that "consumers should not lose their legal rights by complaining to the ombudsman").

262. Andrew Tettenborn, Punitive Damages- $A$ View from England, 41 SAN Diego L. REV. 1551, 1552 (2004).

263. See A. Mitchell Polinsky \& Daniel L. Rubinfeld, Does the English Rule Discourage Low-Probability-of-Prevailing Plaintiffs?, 27 J. LEGAL STUD. 141, 141 (1998).

264. See Rawlings \& Willett, supra note 179, at 312; Insurance Contract Law, supra note 242 , at $65-66$.

265. See supra text accompanying note 237. 
successfully convince insurers to compromise voluntarily in less than half of all confirmed consumer complaints. ${ }^{266}$ By contrast, the FOS convinces parties to voluntarily settle their insurance disputes in guided conciliation, without seeking ombudsman review, approximately ninety-four percent of the time. ${ }^{267}$ Of course, these percentages are not directly comparable. The FOS settlement figure reflects all complaints to the FOS, which are resolved in favor of consumers in one-third to one-half of insurance cases, depending on the relevant line of insurance. ${ }^{268}$ The United States settlement figure, by comparison, reflects only "confirmed complaints" where the regulator has "upheld the consumer position.,"269 It may be easier, or harder, for the FOS to convince losing consumers to settle than it is for regulators to convince insurers who are the subject of confirmed complaints to compromise. Additionally, the methodology for generating these two figures differs. $^{270}$ Nonetheless, the gap in settlement rates is at least a rough reflection of the relative effectiveness of the two different conciliation programs.

Second, the FOS better maintains neutrality than American ADR schemes, even though its jurisdiction is not limited to cases in which this neutrality is easiest to ensure. The best evidence of this neutrality is the support that the FOS enjoys from competing constituencies. Insurers voluntarily created the FOS's predecessor almost three decades ago, ${ }^{271}$ and their enthusiasm for it has not waned in the

266. See supra text accompanying notes 97-101.

267. See Simon Coe, Serv. Manager of the Assessment Unit, Fin. Ombudsman Serv., Presentation 9, 14-15 (Jan. 10, 2008) (presentation slides) (on file with author). Forty percent of insurance cases are assigned to an "assessment team" that resolves insurance cases voluntarily $96.2 \%$ of the time, whereas $60 \%$ of insurance cases are assigned to an "investigation team" that resolves insurance cases voluntarily $92.6 \%$ of the time. The resulting $94.01 \%$ settlement rate in insurance is almost identical to the larger voluntary settlement rate at the FOS. See ANNUAL REVIEW '08, supra note 190, at 1 (reporting $90 \%$ settlement rate); FIN. OMBUDSMAN SERV., ANNUAL REVIEW: FINANCIAL YEAR 2006/07, at 1 (2007), available at http://www.financial-ombudsman.org.uk/publications/ar07/ar07.pdf [hereinafter ANNUAL REVIEW '07] (reporting 94\% settlement rate).

268. See ANNUAL REVIEW' '08, supra note 190, at 44.

269. Compare COMPLAINT Dispositions, supra note 84 , at 1 , with ANNUAL ReVIEW '08, supra note 190 , at 1 . The reason for this discrepancy is that consumers do not have any options within the ADR system when a regulator informs them that their complaint is without merit. Consequently, it is impossible to determine whether or not the consumer "voluntarily" accepts this resolution of the case.

270. In particular, whereas the success rate for FOS conciliation is based simply on whether either party seeks ombudsmen review, the settlement rate for state regulators is based on examination of the individual "disposition codes" that regulators assign to complaints. Compare COMPLAINT DISPOSITIONS, supra note 84, at 1-2, with ANNUAL REVIEW '08, supra note 190 , at 1 .

271. See supra text accompanying notes 183-185. 
interim: a 2007 survey, conducted by the British Insurance Association, reported that $88 \%$ of British insurers are "satisfied with the relationship they have with the FOS," $87 \%$ believe the roles of the FOS and FSA are "reasonably clear," $94 \%$ support the use of the "fair and reasonable" standard, and $75 \%$ believe that the role of the FOS should not change dramatically. ${ }^{272}$

Perhaps even more importantly, this enthusiasm for the FOS is shared by consumers and consumer groups. Among consumers who complain to the FOS, $70 \%$ believe that the FOS "handle[s] complaints efficiently and professionally," and only $12 \%$ disagree. ${ }^{273}$ This positive impression of the FOS was held not only by consumers who felt they had "won" their complaint (with 86\% reporting that they were satisfied with the FOS), but also by those who believed they "lost" their complaint ( $48 \%$ of whom were satisfied with the FOS). ${ }^{274}$ One of the primary consumer rights groups in Britain, Which?, similarly promotes the FOS, noting that it "provides an effective alternative to the court system which levels the playing field between firms and consumers.",275 Another major consumer group, the National Consumer Council, opines that "the FOS continues to do a good job under difficult circumstances" and makes its "service[s] accessible to users.",276

Finally, two independent assessments found that the FOS's process for evaluating consumer complaints is generally impartial. The first, conducted in 2004 by the Personal Finance Research Centre

272. Sec Ass'n of British Insurers, Survey of Members' Experience and Perceptions of the Financial Ombudsman Service 3-4 (Jan. 2008) (on file with author).

273. ANNUAL REVIEW '07, supra note 267, at 60 . Favorable consumer ratings of the FOS should not necessarily be equated with evidence of a well-functioning dispute resolution process. As Sharon Gilad has argued, much of what the FOS does is to "manage" consumers' expectations and communicate with them in a way that engenders their trust and satisfies their emotional needs. See generally Gilad, supra note 179, at 244-45. Favorable consumer perceptions of the FOS may be driven more by this focus on effective communication with consumers than by the underlying quality of the dispute resolution process.

274. ANNUAL REVIEW '07, supra note 267 , at 61.

275. See Which?, Consultation Response Regarding the Hunt Review 2 (Jan. 22, 2008), available at http://www.thehuntreview.org.uk/submissions/submissions.html; see also Interview with Teresa Fritz, Principal Researcher, Which? Money Research Group (Jan. 10, 2008).

276. See Nat'l Consumer Council, The Hunt Review Response to the Call for Evidence to the Independent Review of the Financial Ombudsman Service by Lord Hunt of Wirral MBE 4, 6 (n.d.). The National Consumer Council has opined, more generally, that "[p]rivate sector ombudsmen have delivered significant benefits to consumers for a generation" and "seem generally to work well." See STEVE BROOKER, LESSONS FROM OMBUDSMANIA 3 (2008), available at oparchive.org/tna/20080804145057/http://www.ncc. org.uk/nccpdf/poldocs/NCC198ft_ombudsmania.pdf (last visited Jan. 25, 2009). 
at the University of Bristol, concluded that the FOS provides a "robust," "fair," "reasonable," "flexible," and "efficient" process for resolving consumer complaints. ${ }^{277}$ A more recent independent report struck a more critical tone, noting that the FOS "can seem intimidating and unwelcoming to the less educated" and that it is sometimes perceived to "make[] it up as it goes along."278 Nonetheless, the report repeatedly lauds the FOS's "independence from industry, regulators and consumer bodies" and the "impartial nature of its internal processes. ${ }^{, 279}$

In contrast to the FOS, each of the American schemes reviewed in Part II raise significant questions about third-party neutrality, with the concerns being so significant in the arbitration context that states generally refuse to promote arbitration outside of narrow factual disputes over valuation and medical necessity determinations. ${ }^{280}$ The FOS, by contrast, succeeds in maintaining its neutrality, even though its jurisdiction extends to all types of insurance complaints (and beyond). ${ }^{281}$ Unlike many neutrality-promoting procedural safeguards in arbitration, ${ }^{282}$ the FOS's neutrality does not unduly sacrifice speed or efficiency: the FOS resolves over half of all disputes within three months. ${ }^{283}$

The FOS accomplishes this with roughly the same amount of resources that American insurance regulators devote to dispute resolution. For instance, the number of FOS employees who work on insurance disputes is quite similar to the number of American regulators who focus on resolving insurance disputes. The FOS has about 119 adjudicators who work on insurance matters and about six insurance ombudsmen. $^{284}$ Approximately fifty-five additional FOS

277. See Elaine Kempson, Sharon Collard \& Nick Moore, fair and Reasonable: AN AsSessment of the Financial Ombudsman SerVice 24, $40-41$ (2004), available athttp://www.financial-ombudsman.org.uk/publications/pdf/kempson-report-04.pdf.

278. The Hunt Review: Opening Up, Reaching OUT, AND AIMING High (2008), available at http://www.financial-ombudsman.org.uk/news/updates/LordHunt_Report.html (download "Lord Hunt's report").

279. Id. at $15,21,24,27$.

280. See supra Part II.

281. See supra text accompanying notes 190-191.

282. See Estreicher, supra note 4, at 159.

283. See ANNUAL REviEW '08, supra note 190, at 47. These numbers exclude 'mortgage endowment cases," which involve interest-only mortgages that are coupled with an endowment policy to which payments are made. See id.; Fin. Serv. Auth., How Mortgage Endowments Work (May 4, 2007), http://www.moneymadeclear.fsa.gov.uk/news/product/ endowments/how_mortgage_endowments_work.html. Such endowments have not been used in American markets.

284. See Coe, supra note 267 , at $9,14-15$. 
employees, such as call center staff and support staff, can be allocated to the insurance function of the FOS, resulting in a total of about 180 FOS insurance employees. ${ }^{285}$ By contrast, there were 1723 total employees in state consumer affairs divisions in 2006, 540 of which were complaint investigators and 213 of which were supervisory staff. $^{286}$

Of course, precise comparison of these figures is impossible. First, the two countries are different sizes: the United States has about three times the total insurance premium income as the United Kingdom $^{287}$ and about five times the total population of the United Kingdom. $^{288}$ Second, American consumer affairs divisions perform regulatory functions in addition to complaint conciliation. ${ }^{289}$ A rough, but generous, estimate is that consumer affairs divisions spend half of their time on regulatory activities that are separate from complaint processing and resolution. ${ }^{290}$ These two considerations suggest that direct comparison requires multiplying the number of FOS employees by anywhere from six to ten, resulting in an adjusted figure of roughly between 1080 and 1800 FOS employees who work on insurance. This compares well to the 1723 regulatory complaint handlers in the United States, especially as the United States estimate does not include resources that are devoted to insurance arbitration, while the FOS figure reflects the similar process of ombudsman review.

The caseloads of FOS and American complaint handlers are also roughly comparable to one another. FOS insurance adjudicator caseloads are approximately 160 to 200 cases a year. ${ }^{291}$ By contrast, American complaint investigators have caseloads of about 400 to 600

285. The FOS has about 825 employees, and its insurance caseload is about 17 to $22 \%$ of its total cases, resulting in somewhere between 140 and 180 FOS employees that can be roughly allocated to the insurance function of the FOS. See supra text accompanying notes 190-192. The estimate in the text uses the most conservative estimate of 180 FOS employees dedicated to insurance.

286. RESOURCE MANUAL, supra note 67, at 11.

287. See ASS'N OF BRITISH INSURERS, supra note 182, at 3.

288. See U.S. Census Bureau, International Data Base (IDB) Country Summary: United States, http://www.census.gov/ipc/www/idb/country/usportal.html (last visited Nov. 16, 2008); U.S. Census Bureau, International Data Base (IDB) Country Summary: United Kingdom, http://www.census.gov/ipc/www.idb/country/ukportal.html (last visited Nov. 16, 2008).

289. See supra Part II.

290. Half of responding insurance departments reported that the primary purpose of their Consumer Affairs Divisions is to "assist consumers in a time of crisis" rather than to "investigate violations of the law." See Consumer Services Survey, supra note 67, at 23.

291. See Coe, supra note 267 , at $9,14-15$. 
cases a year, on average. ${ }^{292}$ This discrepancy, while significant, is less than it may initially appear. Compared to the FOS, a higher percentage of consumer calls to American regulators are mere "inquiries" as opposed to "complaints." time-intensive than complaints. While adjudicator case figures do not reflect any inquiries (which are dealt with by the consumer call center), regulator caseload figures often do, because complaint investigators directly receive consumer calls in many (but not all) states. ${ }^{294}$

\section{EXPLAINING THE COMPARATIVE SUCCESS OF THE BRITISH PRIVATE OMBUDSMAN MODEL}

Part III raises a puzzle. Given that so many of the basic building blocks of the FOS resemble insurance ADR programs used in the United States, why is the FOS so much more successful than its American counterparts? This Part proposes an answer to that puzzle that focuses on the comparative institutional architecture of the two ADR schemes. The structure of the FOS, Part IV argues, blends elements of the uncoordinated insurance ADR mechanisms used in the United States, most notably regulator-conciliation and arbitration. Other nonstructural elements of the FOS facilitate the smooth operation of this conglomerate. While the constituent elements of the FOS scheme only differ marginally from individual state insurance ADR schemes, these pieces are thereby deployed within an institutional architecture that creates multiple synergies.

The FOS's blending of ADR elements takes place along at least three dimensions. First, Subpart A argues that the FOS's combination of independent ADR approaches-including insurer-policyholder negotiation, regulator-provided conciliation and state-regulated arbitration-into a single coordinated scheme facilitates an ADR

292. See supra text accompanying note 83 .

293. American regulators receive almost 400,000 complaints and 2.5 million consumer inquiries a year, meaning that only one out of every 7.25 calls is a complaint rather than an inquiry. RESOURCE MANUAL, supra note 67 , at 11 . The FOS handles about 94,000 to 163,000 insurance complaints and inquiries a year. ANNUAL REVIEW '07, supra note 267, at 1; ANNUAL REVIEW '08, supra note 190, at 1. Only about 16,000 to 27,000 insurance cases, or one in six consumer contacts, become formal "cases" that are reviewed by adjudicators. ANNUAL REVIEW '07, supra note 267, at 1; ANNUAL REVIEW '08, supra note 190, at 1. Although many calls do not become cases because they are inquiries, others do not become cases for other reasons: a consumer has not lodged an internal complaint, or the complaint can be resolved quickly. See ANNUAL REVIEW '08, supra note 190, at 13. But even if every call that did not become a complaint was an inquiry, this would still mean that one out of every six calls was a complaint rather than an inquiry.

294. See supra text accompanying note 81 . 
process that is as broad and accessible as conciliation, while remaining as effective and cost-efficient as state-regulated arbitration. It explores how the FOS's ultimate authority to issue binding decisions in the "arbitration" stage has disproportionate trickle down effects that improve the efficacy of earlier, cheaper ADR stages. Subpart B, in turn, contends that the public, but independent, status of the FOS blends private arbitration with the public facets of regulator-sponsored conciliation. Once again, this unusual intermediate position helps the FOS to overcome problems endemic to ADR in America. The FOS's public and unitary status allows it to manage effectively the problem of decision-maker bias while its independence from the regulator counteracts problems associated with the dual identity of regulatorconciliators. Finally, Subpart C explores how the FOS's unique "reasonable fairness" standard blends formal doctrinal precedent with informal industry norms and equitable principles in a way that facilitates the FOS's efficient operation.

\section{A. The FOS's Coordinated ADR Process}

A fundamental principle of effective dispute system design is that most disputes should be resolved by aligning the interests of the competing parties. ${ }^{295}$ Only when this proves impossible should disputes be decided based on which party is "right."296 Finally, only where both an interests-based and rights-based approach proves impossible should the relative power of the parties dictate who prevails. ${ }^{297}$ The explanation for this tiered approach is simple: "in general, reconciling interests is less costly than determining who is right, which in turn is less costly than determining who is more powerful.,298

295. William L. URy, Jeanne M. Brett \& Stephen B. Goldberg, GetTing Disputes RESOlvEd 15 (1993); see also Peter Robinson, Arthur Perlstein \& Bernard Mayer, DyADS. Encouraging "Dynamic Adaptive Dispute Systems" in the Organized Workplace, 10 HarV. NEGOT. L. REv. 339, 360-64 (2005) ("As much as possible, a [Dynamic Adaptive Dispute System] should allow and encourage parties in conflict to make decisions and resolve conflicts on the basis of needs and interests.").

296. URY, BRETT \& GOLDBERG, supra note 295, at 15.

297. Id.

298. Id. In many ways, this dynamic approach to dispute resolution resembles "responsive regulation." See IAN AIRES \& JOHN BRAITHWAITE, RESPONSIVE REGULATION (1992). The idea behind responsive regulation is that enforcement sanctions should start out as relatively nonintrusive and gradually become more severe as needed. Throughout the process, regulators should engage in a dialogue with the regulated entities to encourage compliance. See id. Like tiered dispute resolution, responsive regulation attempts to devote only as much resources as need be to generate the desired outcomes. The key difference, of course, is that responsive regulation and tiered dispute resolution must operate differently 
The FOS employs this tiered approach for resolving consumer insurance disputes by combining ADR elements-including negotiation, conciliation, and arbitration-into a single coordinated scheme. Each successive stage of the FOS process presents a new opportunity for policyholder complaints to be resolved in a way that is one degree further along the "interests-rights-power" spectrum. For instance, strictly requiring that consumers lodge their complaints with insurers prior to initiating a complaint with the $\operatorname{FOS}^{299}$ helps to ensure that all complaints that are susceptible to voluntary settlements are resolved in that fashion. Similarly, funneling all cases through the adjudicator/conciliation stage before the ombudsman/arbitration stage $^{300}$ helps ensure that only the cases where the parties' interests are least aligned reach the ombudsman stage. ${ }^{301}$ Finally, a tiny minority of cases - those presenting novel legal issues or factual issues beyond the capacity of the FOS to assess-are left unresolved by the rights-based ombudsman stage, ${ }^{302}$ subject to the power struggle of litigation.

This ADR structure is an important, if unremarkable, feature of the FOS. In many respects, it resembles the multidoor courthouse proposed by Frank Sander more than three decades ago. ${ }^{303}$ What is remarkable, however, is the way that the FOS implements this tiered approach to ADR resolution. The FOS process is structured so that the authority that exists later in the process, during the rights-based ombudsman/arbitration stage, exerts significant pressure on the earlier stages. Consequently, many disputes that would require significant resources to resolve in an uncoordinated model are resolved through a relatively cheap, interests-based form of $\mathrm{ADR}$, such as negotiation or conciliation, under the FOS model. This trickle-down effect of ombudsman authority helps explain the fact that at each of the FOS's

because of the differences in the underlying enterprises of regulation and dispute resolution. See infra text accompanying notes $370-371$.

299. See supra text accompanying notes 193-199.

300. See supra text accompanying notes 207-226.

301. This happens most often with cases that raise systemic issues. See Sharon Gilad, Juggling Conflicting Demands: The Case of the U.K. Financial Ombudsman Service, $19 \mathrm{~J}$. PUB. ADMIN. RES. \& THEORY (forthcoming 2009) ("High ratios of firms' appeals for an ombudsman's review were typically associated with the FOS's handling of new influxes of complaints of a systemic nature.").

302. See supra text accompanying note 248 .

303. Sander proposed that disputes be routed by a multidoor courthouse to dispute resolution mechanisms that best suited the dispute. See Frank A.E. Sander, Varieties of Dispute Processing, in The Pound Conference: Perspectives on Justice IN THE FUTURE 84 (A. Leo Levin \& Russell R. Wheeler eds., 1979); see also Jeffrey Stempel, Reflections on Judicial ADR and the Multi-door Courthouse at Twenty: Fait Accompli, Failed Overture, or Fledgling Adulthood?, 11 OHоO ST. J. ON DiSP. RESOL. 297 (1996). 
stages, a significant majority of disputes - between eighty and ninetyfive percent-are resolved. ${ }^{304}$ The authority that exists at the end of the FOS structure is thus a central ingredient to the organization's success because it enhances the effectiveness of each of the earlier stages. The FOS's creative use of this authority allows it to transcend the trade-off between accessibility and affordability, on the one hand, and effectiveness, on the other, which seems embedded in American ADR approaches to consumer insurance.

This Subpart teases these ideas out with respect to each stage of the FOS process. It shows how the FOS's coordination of individual ADR approaches significantly enhances the effectiveness of the relatively cheap stages, and contrasts that effectiveness with the largely uncoordinated, though similar, ADR approaches used in American consumer insurance ADR. Because the FOS's coordination operates by allowing later, more expensive ADR stages to influence earlier, faster and cheaper stages, the analysis below proceeds in reverse, with the later links in the FOS chain examined first.

\section{FOS Conciliation in Light of Ombudsman Authority}

The FOS combines the interests-oriented approach of regulatorconciliators and the authority-based approach of arbitrators in a way that allows it to be roughly as cost efficient and accessible as the former while remaining as effective as the latter. As Part III makes clear, FOS adjudicators are roughly comparable to regulatory complaint investigators and have similar (though perhaps slightly lighter) caseloads. ${ }^{305}$ Yet they convince parties to resolve their insurance disputes voluntarily about ninety-five percent of the time, compared to the roughly fifty percent settlement rate of American regulators. ${ }^{306}$

This effectiveness in conciliating settlements at the adjudicator stage is vital to the FOS's success. As described above, voluntary settlement through interest alignment involves comparatively low transaction costs. $^{307}$ For instance, the vast majority of cases that are handled by FOS adjudicators never reach ombudsman review and are resolved relatively quickly-usually within three months. ${ }^{308}$ These facts are central to the entire FOS scheme, given that ombudsmen are

304. See supra text accompanying notes $266-270$.

305. See supra text accompanying notes 291-294.

306. See supra text accompanying notes $266-270$.

307. See URY, BRETT \& GOLDBERG, supra note 295, at 15.

308. See ANNUAL REVIEW '08, supra note 190, at 47. 
significantly more scarce resources than adjudicators and that speedy payments are a key concern for policyholders. ${ }^{309}$ Apart from these efficiency considerations, such interest-based dispute resolution is particularly likely to result in the mutual satisfaction of the parties. ${ }^{310}$

The primary reason that FOS adjudicators enjoy a higher settlement rate than their American counterparts is that their conciliation efforts are linked to the subsequent ombudsman stage, the FOS's version of arbitration. This link exists on several independent levels. First, adjudicators' assessments of cases, which help to frame the conciliation process, strongly resemble ombudsman decision making. This is because adjudicators are trained by ombudsmen, seek advice from ombudsmen on individual cases, learn from ombudsmen over time, and use ombudsman decisions to help conciliate cases. ${ }^{311}$ Because ombudsmen have the dual roles of deciding individual cases and training and advising adjudicators, ombudsmen also help to shape an institutional culture that impacts the decision making heuristics and instincts of individual adjudicators. ${ }^{312}$ The link has real results: as the FOS explains, "[y]our adjudicator will have seen many very similar cases before - and will have a very good idea of how the ombudsman would be likely to view your case.",313

This link in the decision-making processes of adjudicator/ conciliators and ombudsmen/arbitrators significantly enhances the effectiveness of conciliation. Insurers and consumers are generally willing to accept adjudicators' framing of disputes during conciliation precisely because appealing to an ombudsman will not typically change the outcome, but will result in increased delay, costs, and stress to both parties. Insurers, of course, learn this fact from experience. ${ }^{314}$ And adjudicators communicate this link between the conciliation process and ombudsman review to consumers as well: they inform consumers that adjudicators' assessments are highly predictive of

309. See Interview with Simon Coe, supra note 224.

310. See id.

311. See Gilad, supra note 179, at 232-33, 241 (describing the training of adjudicators by ombudsmen and noting that adjudicators were "encouraged to seek an ombudsman's advice before issuing their decision whenever" they were unsure about an issue); Interview with Simon Coe, supra note 224; Interview with Ray Neighbour, supra note 230.

312. See Interview with Walter Merricks, supra note 257.

313. Fin. Ombudsman Serv., Information for Businesses Covered by the Ombudsman Service (Feb. 27, 2008), http://www.financial-ombudsman.org.uk/faq/businesses/answers/ decide_cases_a2.html.

314. See Interview with Ray Neighbour, supra note 230. 
ombudsmen's decisions and explain the rationale for their view based on FOS source materials. ${ }^{315}$

A second link between adjudicator/conciliation and ombudsmen/ arbitrators is that both are part of a structure that has the authority to bind insurers. Even if ombudsmen frequently overturned adjudicators' decisions, the mere fact that adjudicators are part of an organization that can definitively resolve consumer complaints (at least those under $£ 100,000$ ) affords them significantly more credibility than their American counterparts, regulator-conciliators. ${ }^{316}$ This is particularly true with respect to consumers. A large body of work in psychology shows that when individuals perceive a dispute resolution process to be procedurally fair, they are more likely to accept the results and, correspondingly, less likely to appeal those decisions. ${ }^{317}$ Disputants are more likely to view ADR processes as procedurally fair when they have a chance to participate personally in the process and communicate with the decision maker. ${ }^{318}$ Because adjudicators are part of an organization with the authority to resolve consumer disputes, FOS complainants often feel that they have this "voice" in the $\mathrm{ADR}$ process once a complaint goes through the adjudicator stage. $^{319}$

The third, and final, link between the adjudicator and ombudsman stages of the FOS process is that, when deciding cases, ombudsmen have access to all papers relating to the case, including materials generated during the earlier conciliation process. ${ }^{320}$ Moreover, insurers that seek ombudsman review typically must explain in writing why they are doing so. ${ }^{321}$ Especially for insurers, who are repeat players, ombudsmen can use this information to assess

315. See, e.g., Letter from Simon Chong, Adjudicator, Fin. Ombudsman Serv., to Anonymous (Aug. 18, 2005) (on file with author) ("[Y]ou may ask for an ombudsman's decision[, but] I should tell you I consider that unless you are able to provide any further evidence or arguments, an ombudsman's decision is unlikely to differ from what I have said above.").

316. See Interview with Ray Neighbour, supra note 230.

317. See generally E. Allan LIND \& TOM R. TYLER, THE SOCIAL PSYCHOlOGY OF Procedural Justice 81-82 (1988); Laurens Walker, E. Allan Lind \& John Thibaut, The Relation Between Procedural and Distributive Justice, 65 VA. L. REv. 1401, 1402-03 (1979).

318. LIND \& TYLER, supra note 317 , at 100-05.

319. See generally Gilad, supra note 179, at 232-35 (detailing the various strategies of the FOS in attempting to satisfy the emotional needs of complainants, and thus convince them not to appeal to an ombudsman). One way that FOS adjudicators seek to give complainants voice, and thus avoid an appeal to an ombudsman, is by "quoting an approximation of the complainant's statements on the complaint form." Id. at 235.

320. See Interview with Melissa Collett, supra note 208.

321. See id. 
whether parties are seeking ombudsman review because they have legitimate disagreements with adjudicators, or whether they are simply doing so as a matter of course. ${ }^{322}$ In the latter situation, the ombudsman can refer the firm to the Financial Services Authority (FSA) for regulatory investigations. ${ }^{323}$ Perhaps more importantly, such firms will inevitably develop a reputation within the FOS that may well affect how future cases are handled.

Ultimately, then, the ombudsman/arbitration stage of the FOS significantly influences the earlier adjudicator/conciliation process even though, as is usually the case, neither party ever invokes it. In this way, FOS adjudicators are cloaked with quasi-authority because of the links between their conciliation/evaluation and the authority of ombudsmen to render decisions that are binding on insurers. This quasi-authority significantly enhances settlement rates from conciliation. Additionally, it improves consumer confidence in the insurance industry by giving consumers a relatively accessible and independent option for determining whether their insurer has treated them fairly. ${ }^{324}$

To be sure, this quasi-authority has its costs, as it may undermine the benefits of interest alignment described above. ${ }^{325}$ Most notably, it allows adjudicators to discourage consumers from seeking ombudsman review even when the adjudicator is wrong about the underlying merits of the case. Such misguided pressure may create its own repeat-player advantage for insurers, who are comparatively wellequipped to assess the relative quality of an individual adjudicator's assessment. $^{326}$ Additionally, consumers who accept an adjudicator's determination that their complaint is without merit may not feel the sense of resolution that often accompanies interest alignment. ${ }^{327}$

322. See Gilad, supra note 301 ("[The FOS] was inclined to invoke the threat of passing information to the FSA when uncooperative firms persistently challenged adjudicators' decisions by appealing for ombudsmen's reviews with regard to a large number of similar complaints.").

323. See id. (noting that the FOS followed through on such threats).

324. See Stempel, supra note 90, at 214 (arguing that evaluative mediation helps inform parties of their background legal rights). 298.

325. See discussion of Ury, Brett and Goldberg, supra text accompanying notes 295-

326. Ultimately, though, this problem is limited given how infrequently ombudsmen actually overturn adjudicators' decisions.

327. See supra text accompanying note 310 (indicating that voluntary settlement is more likely to produce mutual satisfaction in results). But cf. supra text accompanying notes 271-272 (referencing data that complainants to FOS report high level of satisfaction). 
This quasi-authority of FOS adjudicators is a striking contrast with regulator-conciliation in the United States, which is generally completely untethered from any rights-based decision-making process. ${ }^{328}$ Unlike FOS officials, American regulatory conciliators must generally rely entirely on aligning the parties' interests in order to convince them to resolve a case voluntarily. But, most significant insurance coverage disputes are zero-sum games: the consumer's primary interest is in the payment of the claim, while the insurer's primary interest is in not paying the claim. Moreover, the insurer will often have very little interest in preserving the relationship, as the insured's loss (as well as her willingness to complain) provides prima facie evidence that she is a "bad" risk. As the literature on ADR has long recognized, aligning the interests of such competing parties is generally quite difficult. ${ }^{329}$ These facts may help to explain the comparatively poor settlement rate of American regulatorconciliators. $^{330}$ They also contribute to the inability of American policyholders to assess whether their insurer has handled a claim fairly. $^{331}$

Admittedly, - regulator-conciliators may be able to align the interests of insurers and policyholders in ways that FOS adjudicators cannot by leveraging their regulatory authority to induce settlement. ${ }^{332}$ For instance, a regulator-conciliator might suggest that an insurers' refusal to compromise may lead to heightened regulatory scrutiny in the future. ${ }^{333}$ Ultimately, though, the use of regulatory leverage to align interests is more likely to harm the bargaining dynamic than to help it because so few consumer complaints actually implicate regulatory

328. See supra Part II.A.

329. See John Thibaut \& Laurens Walker, Procedural Justice: A PSYCHOLOGICAL ANALYSIS 8-15 (1975) (explaining that mediation is often impossible when the parties have "noncorrespondent outcomes," meaning that for one party to win, the other must lose); URY, BRETT \& GOLDBERG, supra note 295, at 16 ("In some disputes, the interests are so opposed that agreement is not possible.")

330. See supra notes 97-101 and accompanying text (discussing poor settlement rates of insurance conciliation by state insurance departments).

331. See supra text accompanying note 30.

332. Of course, there are other cases in which regulators can, and do, align the interests of consumers and insurers. This is particularly likely in small value cases or cases in which the reputational consequences to the insurer of denying coverage are significant. As Part I suggests, ordinarily the reputational impact of a claims denial will be less for an insurer than the value of denying the claims. See supra text accompanying notes 24-30. But this is not always true. For instance, cases that attract significant media coverage may invert the ordinary calculus. This may well be why the success rate of insurance mediation in mass disasters is so high. See supra text accompanying notes 100-101.

333. Such threats of future regulator action are described in Serber, supra note 5, at 338. 
issues. In 2007 , complaint handlers referred only $0.4 \%$ of confirmed consumer complaints to their market conduct divisions, and in 2006 the percentage was even smaller. ${ }^{334}$ Complaint handlers' implicit or explicit threats of such regulatory action are therefore unlikely to prove credible. In fact, they may be counterproductive: insurers facing threats of regulatory action may be less willing to compromise in response to a consumer complaint, fearing that such compromise may be used against them in a subsequent regulatory action. ${ }^{33}$

\section{The Call Center and the Case Fee}

A second way that the FOS leverages the later, more involved ADR stages to facilitate early and efficient resolution of disputes is through the case fee that its call center levies on insurers. As described above, once a complaint is elevated to an adjudicator, the consumer's insurer is charged a $£ 450$ case fee. ${ }^{336}$ This structure not only provides the FOS with funding, but it allows call center employees to convince insurers to settle cases before the case fee is levied against them. It is therefore partly responsible for the significant percentage of calls that are "weeded out" at this stage of the FOS process: in most years, only one out of every six calls to the call center results in a full-blown case that reaches an adjudicator. ${ }^{337}$ This narrowing of calls that turn into cases not only promotes early-stage resolution of disputes, but it avoids the direct involvement of both ombudsmen and adjudicators. It thus contributes to the comparatively low caseload of adjudicators, as compared to American regulator-conciliators. ${ }^{338}$

As with the adjudicator stage, early dispute resolution by the call center uses the later, more expensive stages of the tiered FOS process to facilitate early resolution of cases. Because the FOS conducts both early- and late-stage $\mathrm{ADR}$, call center employees can leverage the expense that exists later on in ways that would otherwise be impossible. Although regulator-conciliators may ordinarily focus

334. COMPLAINT Dispositions, supra note 84, at 1.

335. See Gilad, supra note 301 ("Firms resisted informal conciliation of complaints when concerned that their agreement to redress an individual complaint might be interpreted by the regulator or the media as entailing compensation awards to a large number of other customers in similar circumstances.').

336. See supra text accompanying note 205.

337. Gilad, supra note 301; ANNUAL REVIEW '07, supra note 267, at 1 . There are a number of other reasons that calls are not elevated, including that no internal complaint was filed, the call was clearly not meritorious, or the call was merely an inquiry. ANNUAL REVIEW '08, supra note 190, at 13.

338. See supra text accompanying notes 291-294. 
insurers on the potential costs of litigation, those costs are always hypothetical for insurers because their refusal to compromise may not necessarily lead to litigation. ${ }^{339}$ By contrast, because FOS call center employees impose the case fee, they can guarantee reluctant insurers that failure to compromise early will result in subsequent ADR costs. Like FOS adjudicators, and unlike American regulator-conciliators, FOS call center employees thus enjoy a quasi-authority in attempting to convince insurers to settle cases early.

In fact, the distinctions between the FOS and American schemes run even deeper. American insurers do indeed pay for the dispute resolution services of regulators, but they do so indirectly, through premium taxes. ${ }^{341}$ Because the amount of taxes that insurers owe is not influenced by how often their particular consumers complain to regulators, insurers have no incentive to use the common resource of regulator-facilitated conciliation judiciously by resolving cases quickly. The FOS avoids this "tragedy of the commons" by forcing insurers to internalize the costs of resolving disputes with their policyholders. This provides British insurers with an incentive to avoid consumer complaints in the first place and to settle those complaints quickly before the imposition of a case fee.

\section{The Internal Complaint Process and Subsequent FOS Review}

Finally, the various links between firms' processing of internal consumer complaints and subsequent FOS review once again use the FOS's tiered and interconnected design to promote cheap and effective dispute resolution. Recall that all consumer complaints must be lodged with the underlying firm before a consumer can initiate the FOS process. $^{342}$ Firms are statutorily required to investigate and respond to internal complaints, and these responses form the basis of the FOS's subsequent evaluation of the case. ${ }^{343}$ Informal estimates suggest that consumers who lodge internal complaints seek FOS

339. See generally Susan S. Silbey \& Sally E. Merry, Mediator Settlement Strategies, 8 LAW \& POL'Y 7, 13 (1986).

340. This pseudo-authority may be similar to the authority that Minnesota regulatorconciliators possess by virtue of their capacity to link quick complaint resolution with public disclosure. See supra text accompanying note 95. ments).

341. Randall, supra note 114, at 643 (explaining funding of state insurance depart-

342. See supra text accompanying note 193.

343. This is true of review for both adjudicators and ombudsmen. See supra text accompanying notes $213-214,239-241$. 
assistance between two to ten percent of the time. ${ }^{344}$ This internal complaint resolution obviously reduces the number of complaints that reach the FOS, and may be one of the reasons why FOS adjudicators enjoy lighter caseloads than their American counterparts. ${ }^{345}$

Once again, the effectiveness of insurers' internal complaint handling in the United Kingdom is significantly enhanced by the FOS's tiered ADR process. Because firms' internal complaint files form the basis of subsequent FOS review of complainants' cases, firms have a natural incentive to take this process seriously. ${ }^{346}$ First, a deficient internal complaint file will prejudice a firm's case if it ends up at the FOS. Second, it may cause the FOS to refer the matter to the FSA for regulatory action and tarnish the firm's larger reputation within the FOS. ${ }^{347}$ The FOS can thus promote effective regulation of the internal complaint-handling process precisely because adjudicators and ombudsmen review these files in the ordinary course of resolving disputes.

Encouraging insurers to investigate and process consumer complaints more carefully has the potential to improve insurers' resolution of consumer disputes. Insurers may incorrectly deny a claim and subsequently reject consumer complaints because they rely on a claims-handling bureaucracy whose members may be encouraged (directly or indirectly) to keep payments low and profit high. ${ }^{348}$ Even insurers who instill in their employees a culture of upholding claims in cases of doubt must nonetheless "proceed[] by routinizing and simplifying [the] inherently complex and difficult procedures" of

344. See Gilad, supra note 301 (noting that no formal statistic is available, but reporting her own estimate based on interviews with FOS employees); Merricks Speech, supra note 213 ("In most classes of business, one might hope that firms would resolve all but a tiny minority of complaints - leaving perhaps between $2 \%$ and $5 \%$ to be referred to the ombudsman."). A comparative figure for American regulators is difficult to estimate, as internal complaints may not be recorded, aggrieved insurance consumers often pursue legal recourse without consulting regulators, and there are only sporadic requirements that insurers inform consumers about their right to complain.

345. See supra text accompanying notes 291-294.

346. See Interview with Adam Samuel, Complaint Handling Consultant (Jan. 7, 2008).

347. See SAMUEL, supra note 195, at 676-77 (discussing fines for inappropriate complaint handling, but suggesting that the regulator has not been sufficiently aggressive on this front, as one firm was "notorious" for its complaint handling "for many years in Ombudsman circles which had repeatedly asked regulators to take action").

348. See BAKER, supra note 14, at 54-55, 106 (quoting Hayseeds Inc. v. State Farm Fire \& Cas., 352 S.E.2d 73, 78-79 (W. Va. 1986)) (noting that "the vast majority of insurance claims are resolved according to the insurance law of the insurance adjustor" and exploring the competitive pressures that may be placed on such adjustors). 
claims handling. ${ }^{349}$ The United Kingdom's experience suggests that forcing insurers to disentangle the jobs of claims handlers and complaint handlers could help to limit the prospect that an intransigent insurance claims bureaucracy would stand in the way of resolving legitimate consumer complaints. ${ }^{350}$

Of course, as described above, state regulators do make nominal efforts to link the internal complaint process and the regulatory complaint process. They often request that consumers first contact their insurer with complaints, and insurers are subject to some minimal regulation of their internal complaint handling process. ${ }^{351}$ But outside of the realm of health insurance, these links are too weak to create any real incentive for insurers to take internal complaint handling seriously because, unlike with the FOS, the results of that complaint handling are not generally incorporated into subsequent dispute resolution. ${ }^{352}$ Nor could they be: insurers are free to ignore oral complaints, they need not provide written responses to any complaints, and their responses to consumer complaints that are lodged with the regulator need not relate to any prior analysis of the complaint. ${ }^{353}$

\section{B. The Role of the Regulator and Private Parties in Dispute Resolution}

The second structural way in which the British scheme successfully melds the two ADR approaches used in the United States is by relying on a nonregulatory, public organization to handle disputes. Unlike American states, in which insurance regulators double as conciliators, FOS complaint handlers are largely independent of the British insurance regulator. At the same time, the FOS does not rely on fragmented private decision makers as in American insurance arbitration. Instead, the FOS is a unitary, public entity. The FOS's organizational structure therefore straddles the two options that currently exist for the $\mathrm{ADR}$ of consumer insurance disputes in the United States. This intermediate position allows the

349. H. Laurence Ross, Settled out of Court: The Social Process of INSuRANCE ClAiMS ADJUSTMENTS 135 (1970).

350. See JAMES, supra note 6, at 205-07. Although the benefits of internal review are "not clear cut" because some firms have poor internal complaint mechanisms, in general the "development of internal procedures has been one of the additional benefits flowing from the ... ombudsman scheme" as most complainants will have their complaint "satisfactorily resolved" internally. Id.

351. See supra text accompanying notes 71-76.

352. See generally Part II.A.

353. See id. 
FOS to maintain its neutrality, promote the cooperation of disputants, and ensure that regulatory issues are appropriately addressed.

\section{The FOS's Independence from the Regulator}

The FOS's independence from the British Insurance regulator, the FSA, contributes significantly to its success. ${ }^{354}$ Most importantly, this separation enhances the FOS's independence. The primary tasks of insurance regulators are to ensure insurers' solvency and examine insurers' market conduct for regulatory violations. ${ }^{355}$ Each of these tasks requires affirmative engagement with the industry, meaning that regulators' independence from insurers is often impossible, and perhaps even undesirable. ${ }^{356}$

By contrast, housing complaint handlers in their own separate organizational setting promotes a culture of independence. First, it facilitates the ability of lead officials to develop such a culture internally, because of the organization's unity of purpose. ${ }^{357}$ Thus, FOS ombudsmen consistently emphasize to adjudicators, call-center employees, and other FOS staff the centrality of the FOS's independence and neutrality. ${ }^{358}$ By contrast, a regulator would have difficulty promoting this message, given the close relationship between regulators and industry. ${ }^{359}$ Second, a complaint organization's

354. See supra text accompanying note 215 .

355. See generally ETTLINGER ET AL., supra note 36 .

356. See Richard B. Stewart, The Reformation of American Administrative Law, 88 HARV. L. REV. 1667, 1684-85 (1975) (noting widespread acceptance of the notion that capture often results from innocuous repeat interactions between regulators and the subjects of that regulation). Given the necessity of dialogue between industry and regulators and the simultaneous risk that that can lead to capture, some have argued that regulators who handle solvency and systemic risk concerns should be separated from those who deal with consumer protection issues. See Oren Bar-Gill \& Elizabeth Warren, Making Credit Safer, 157 U. PENN. L. REV. 1 (2008); Heidi Mandanis Schooner, Consuming Debt: Structuring the Federal Response to Abuses in Consumer Credit, 18 LoY. CONSUMER L. REV. 43, 48 (2005); Adam J. Levitin, Hydraulic Regulation: Regulating Credit Markets Upstream 15 (Sept. 7, 2008) (unpublished manuscript), available at http://www.law.georgetown.edu/faculty/events/ userfiles/file/workshops/Fall2008/Levitin\%20Workshop\%20Presentation.pdf ("The safetyand-soundness mission is incompatible with consumer protection because practices that might be profitable and thus increase banks' safety-and-soundness might also be abusive and unfair to consumers.").

357. Interview with Walter Merricks, supra note 257 (opining that the FOS is able to instill in its employees an ethos of resolving cases fairly and independently because that is its central mission).

358. See id:; Gilad, supra note 187, at 911 (describing the ombudsman's frequent emphasis on the individualized and case-specific nature of FOS work).

359. See JAMES, supra note 6, at 220-21 (describing how "the ombudsman's independence may be compromised by, for example, subtle and unacknowledged pressure from ... those within the industry concerned" and suggesting that this may happen when 
lack of regulatory authority allows its employees to articulate their role clearly to consumers, insurers, and other stakeholders. Indeed, FOS communications to consumers repeatedly explain that the purpose of the FOS is simply to resolve disputes fairly, and not to punish wrongdoers. ${ }^{360}$ Over time, this message tends to become a selffulfilling prophecy, with employees embracing the message of independence that they describe to outsiders. ${ }^{361}$

This culture of independence makes complaint handling organizations such as the FOS less susceptible to some of the problems that plague American regulator-conciliators. For instance, faced with resource constraints, the FOS seeks to streamline its dispute resolution process rather than to set it aside completely (as do some regulators). ${ }^{362}$ This might entail standardizing the resolution of certain types of complaints or encouraging firms' cooperation by assuring confidentiality. ${ }^{363}$ Similarly, because the FOS defines itself by its independence, its employees are probably less likely to "deselect" cases based on nonneutral principles than American regulatorconciliators. $^{364}$

The FOS's independence from the regulator also facilitates industry cooperation by decreasing insurers' fear that settling individual cases will trigger enhanced regulatory scrutiny. Although the FOS reports patterns of complaints or complaints raising systemic issues to the regulator, ${ }^{365}$ it is "not in the business of shopping [firms] to the regulator for minor things" and will tend to refer only "matter[s] that instinctively call[] for ... regulatory intervention."

ombudsman are selected by "a regulatory body closely linked with the industry"); James \& Morris, supra note 8, at 174 ("[T] oo intimate a relationship with the regulator can raise questions about the genuine independence of the ombudsman.'); Interview with Teresa Fritz, supra note 275 (suggesting that the FOS can maintain its neutrality because, unlike the FSA, it does not affirmatively scrutinize market actors and is merely responsive to consumer contacts).

360. See, e.g., Letter from Heather Clayton, supra note 246.

361. See Gilad, supra note 187, at 911 (arguing that the FOS's frequent emphasis on the individualized and case-specific nature of its work, which was designed to avoid being perceived as a regulator, created a self-reinforcing trend).

362. See supra text accompanying notes 102-113.

363. See Gilad, supra note 301.

364. Compare supra text accompanying notes $114-117$, with Gilad, supra note 301 , at 19 (explaining that the FOS was motivated to avoid inconsistency in its decision making, especially as firms would often track FOS decisions in order to detect potential inconsistencies). Of course, such misfeasance is possible at the FOS as well. But the FOS has relatively robust methods for identifying nonneutral decision making. See infra text accompanying notes 393-398.

365. See supra text accompanying note 220 .

366. Gilad, supra note 301 , at 13 (quoting FOS executive). 
insurers are reportedly more willing to compromise in individual cases because they need not fear that their regulator will interpret such compromise as a concession of improper behavior. ${ }^{367}$ By contrast, it is possible that insurers in the United States are hesitant to settle individual cases through regulatory-facilitated conciliation because they fear that admitting a mistake will make them "look bad" to their regulator. $^{368}$

Undeniably, there are a number of potentially significant drawbacks to disaggregating complaint handling and regulation. Perhaps the most significant cost is the potential for regulators and complaint handlers to develop conflicting views, leading to uncertainty in the industry. Indeed, the FOS and FSA do not always coordinate well and the FOS is often criticized for acting as a regulator rather than an adjudicator. ${ }^{369}$ While a number of formal channels exist to address these issues, ${ }^{370}$ they are imperfect. Ultimately, though, the conflicts that stem from disentangling the jobs of complaint handlers and regulators can be managed because the roles of regulators and complaint handlers are fundamentally different. Regulators attempt to avoid abstract problems that may occur in the future while complaint handlers attempt to resolve specific problems that have occurred in the past. Indeed, the fact that insurance regulators handle consumer complaints is attributable largely to historical accident as opposed to thoughtful institutional design. ${ }^{37}$

A second cost to disentangling complaint handling and regulation is that regulators often rely on consumer complaints to help guide their market conduct analysis. ${ }^{372}$ Even if a complaint handling entity were required to report systemic issues or patterns of complaints to a regulator, as the FOS is, the complaint handling organization might be less adept than the regulator at identifying these regulatory problems

367. See Interview with Harriet Quiney, Partner, Fishburns Solicitors (Jan. 10, 2008) (opining that big firms would worry more about resolving cases if the FOS were a branch of the regulator, as they would be cautious about revealing facts that might prejudice them, even if they did not implicate regulatory issues); Interview with Linda Smith, Policy Team Manager, Ass'n of Indep. Fin. Advisors (Jan. 11, 2008) (suggesting that the FOS's independence from the regulator limits insurers' perception that any concession or error could be used against them in subsequent regulatory actions).

368. See supra text accompanying note 335.

369. See Gilad, supra note 187, at 917 (describing "firms' allegations that the ombudsman was inappropriately assuming the role of a regulator").

370. See supra text accompanying notes 216-221.

371. See Whitford \& Kimball, supra note 5, at 661-67.

372. 1 NaT'l ASS'N OF INS. COMM'RS, MARKET REgUlation HANDBOOK (2008) (on file with author). 
from complaint data. ${ }^{373}$ Additionally, individual adjudicators may have an incentive to refrain from referring firms to the regulator in order to increase their willingness to compromise in individual cases. ${ }^{374}$ Indeed, these hypotheses are arguably consistent with firms' reported decreased fear of regulatory scrutiny as a result of compromising with the FOS.

Although legitimate, these drawbacks are limited and appear to strike an effective balance between facilitating regulation and promoting compromise. First, the actual impact on market conduct analysis of indirectly funneling complaint data to the regulator, rather than allowing the regulator to collect that data on its own, is speculative and requires further study. Second, although substantial fluctuations in consumer complaints can alert regulators to significant regulatory issues, consumer complaints are ultimately only a blunt instrument for guiding market conduct analysis. As noted earlier, a remarkably small percentage of complaints are referred to regulators' market conduct divisions. ${ }^{375}$ And consumers of a particular insurer may be more likely to complain to a regulator for a variety of reasons, only some of which suggest a regulatory issue. ${ }^{376}$ For these reasons, regulators might be better off if they focused their market conduct analysis on insurers' internal complaint records rather than complaints made directly to their offices.

\section{The FOS as a Public Entity}

Despite its formal separation from the regulator, the FOS does not utilize individual, private decision makers as in American arbitration. The FOS is a unitary public entity and, as with insurance regulators, it is operated entirely by public employees. ${ }^{377}$ Like many segments of the American government, the FOS is thus a state-run

373. This might be true if, for instance, regulators are better able to identify regulatory issues from complaint data than a complaint handling organization such as the FOS.

374. See Gilad, supra note 301 (finding mixed evidence of such negotiations).

375. See supra text accompanying note 84 .

376. For instance, the insurer could clearly refer disgruntled consumers to the regulator, or the insurers' policyholders might tend to be relatively sophisticated, and thus likely to lodge complaints, due to the insurers' underwriting strategy.

377. The idea of publicly provided ADR was first promoted by Frank Sander. See Frank A.E. Sander, Varieties of Dispute Processing, in THE POUND Conference: PERSPECTIVES ON JuSTICE IN THE FUTURE 65, 65-87 (A. Leo Levin \& Russell R. Wheeler eds., 1979); see also Judith Resnik, Failing Faith: Adjudicatory Procedure in Decline, 53 U. CHI. L. REv. 494, 536 (1986). Sander's call for a "multidoor courthouse" largely envisioned the judiciary providing this ADR role, however. See Sander, supra, at 65-87. By contrast, the FOS is independent from the British judiciary. 
provider of $\mathrm{ADR}^{378}$ despite its categorization as a private ombudsman. $^{379}$ This structure helps avoid a number of well-known pitfalls from privatizing the ADR of consumer disputes.

First, as discussed earlier, arbitrators may tend to favor repeat players such as insurance companies because they depend on them for business and develop relationships with them over time. ${ }^{380}$ A unified public body such as the FOS can monitor the independence of its employees to prevent this repeat-player advantage. Indeed, the FOS goes to great lengths to assure the independence of individual adjudicators: case files are randomly checked each month by a quality assurance team; ombudsmen directly review adjudicator case files in the course of their own review; and adjudicators' claims-resolution patterns are tracked to identify statistical anomalies. ${ }^{381}$ Where consumers believe that an adjudicator or an ombudsman is biased, they can lodge a complaint with an "independent assessor," who considers the propriety of the FOS employee's behavior (but not the merits of the underlying complaint), and where appropriate, orders the FOS to pay redress. $^{382}$ Moreover, because the individual adjudicators and ombudsmen who deal with a case are not chosen by either party and no competing private entities provide this service, there is no opportunity for repeat players to select sympathetic decision makers. This system of internal checks on employees' behavior is far superior, and easier to implement, than the regulation of independent, autonomous, private arbitrators. ${ }^{383}$

As noted above, the FOS's public status also allows it to identify and address complaints that raise broad regulatory issues. By contrast, insurance arbitration can suppress information about insurers' practices, limiting both consumer knowledge and regulatory

378. See generally Judith Resnik, Many Doors? Closing Doors? Alternative Dispute Resolution and Adjudication, 10 OHIO ST. J. ON DISP. RESOL. 211, 214 (1995) (describing the increasing use of ADR mechanisms by various elements of the federal government and arguing that "ADR has become an integral part of the state's mechanisms for responding to disputes").

379. As explained earlier, a private ombudsman resolves disputes between private parties, and it need not itself be a private entity. See supra note 6 and accompanying text.

380. See supra text accompanying note 160 .

381. See Gilad, supra note 179, at 244 ("Managers conducted an intensive random quality assurance review of adjudicators' decisions ...."); Interview with Ray Neighbour, supra note 230 .

382. ANNUAL REVIEW '08, supra note 190, at 74-77.

383. See supra text accompanying note 169 (noting limitations of monitoring and regulating private decision makers for neutrality); cf. Stempel, supra note 165, at 260-64 (advocating for regulation and licensing of arbitrators). 
scrutiny. ${ }^{384}$ A unitary public entity such as the FOS cannot only identify regulatory issues much better than independent arbitrators, but it can coordinate with the regulator to handle these situations cooperatively. ${ }^{385}$

Finally, a unitary, public complaint handling entity provides greater transparency than a system of private adjudicators. Private decision makers will inevitably use different and potentially conflicting approaches for resolving cases, which can indirectly exacerbate the repeat-player advantage. ${ }^{386}$ By contrast, a unitary, public entity can more easily assure consistency through internal monitoring, communication among decision makers, and dissemination of decision-making criteria, as described below. ${ }^{387}$

\section{The Reasonable Fairness Standard}

A final way in which the FOS scheme blends elements of the various insurance ADR approaches used in America is through its decision-making criterion of "reasonable fairness." In certain ways, the reasonable fairness standard resembles ordinary law: its content is developed in publicly available ombudsman decisions that develop over time and are subject to limited judicial review. ${ }^{388}$ In other ways, though, the reasonable fairness standard more closely resembles broad equitable principles that tend to inform conciliation and some forms of arbitration: it is flexible, focuses on fairness, and does not constitute binding precedent for future cases. ${ }^{389}$ This strategic combination of two alternative approaches once again harnesses many of the benefits of each approach while limiting their pitfalls.

The legalistic characteristics of the fair and reasonable standard help mitigate some of the problems that vex consumer ADR in the United States. First, the publication of ombudsman decisions explaining and applying the fair and reasonable standard ${ }^{390}$ enhances the consistency of FOS decision making in the same way as legal precedent, by providing a baseline against which future cases should be compared. This helps to offset both the "deselection" that can

384. See supra text accompanying note 161.

385. See Memorandum of Understanding, supra note 215.

386. See supra text accompanying note 171.

387. Gilad, supra note 301 (describing each of these efforts at coordinated decision making and the way in which multiple FOS stakeholders monitor adherence to such consistent decision making).

388. See supra text accompanying notes 222-226, 242-245.

389. See supra text accompanying notes $222-226,242-245$.

390. See supra text accompanying note 252 . 
occur in regulator-conciliation and the alleged "lawlessness" of insurance arbitration. $^{391}$ It also limits the repeat-player advantage of insurers, who tend to benefit from inconsistency, which allows more room for them to "game the system."392 Additionally, publication of ombudsman decisions provides guidance to the industry about its practices $^{393}$ and ensures that the content of the fair and reasonable standard is subject to public scrutiny and accountability. ${ }^{394}$

Second, the role of precedent in ombudsman decisions also harnesses core benefits of the legal process. Recall that while ombudsmen are not legally bound by their earlier decisions, ombudsman decisions often use analogical reasoning to apply or distinguish previous opinions and must demonstrate an awareness of the law under the "perverse and irrational" standard of review." As with judicial precedent, this process facilitates consistency over time and across cases, but can nonetheless evolve to address novel situations. ${ }^{396}$ It also produces decisions that reflect the collective views of multiple experts, which are generally much wiser than any individual expert's analysis. ${ }^{397}$ Finally, it constrains the authority of ombudsmen by forcing them to articulate their decisions in written form based on predefined rules ${ }^{398}$

At the same time, the nonlegalistic elements of the reasonable fairness standard provide the FOS with important benefits that would be undercut by the use of a strictly legalistic standard. Because the standard is not subject to formal binding precedent and is broad and grounded in common sense, FOS adjudicators who are generally not

391. See supra text accompanying notes 114-117, 160.

392. See supra text accompanying note 160 .

393. A recent survey of British insurers found that "one-half [of respondents] think anticipation of future FOS rulings impact upon business decisions." Ass'n of British Insurers, supra note 272, at 4; see also JAMES, supra note 6, at 216 ("Decisions made in individual cases may provide a body of informal case law which can affect the way in which those within an industry formulate policy and design procedures.").

394. See Fin. Ombudsman Serv., supra note 252.

395. See supra text accompanying notes $242-245$ (describing the role of precedent in ombudsman decisions applying the fair and reasonable standard); Financial Services and Markets Act, 2000, c. 8, § 228(2) (Eng.); JAMES, supra note 6, at 216.

396. See generally O.W. HolmES, JR., THE COMMON LAW 35 (1881); Emily Sherwin, A Defense of Analogical Reasoning in Law, 66 U. CHI. L. REv. 1179,1189 (1999); Cass R. Sunstein, On Analogical Reasoning, 106 HARV. L. Rev. 741, 745 (1993).

397. See generally James SuROWIECKI, THE Wisdom of CrowdS: Why THE MaNy Are SMarter Than the Few and How Collective Wisdom Shapes Business, Economies, SOCIETIES, AND NATIONS (2004) (arguing that groups of people are collectively smarter than individuals under certain conditions).

398. See Stanley Fish, Doing What Comes Naturally: Change, Rhetoric, and THE PRACTICE OF THEORY IN LiTERARY AND LEGAL StUdies 372-98 (1989). 
legally trained can apply it with reasonable success. ${ }^{399}$ They need not analyze traditional legal sources or even rigorously distinguish or apply prior ombudsman decisions to do so. ${ }^{400}$ Rather, they can explain their decisions in layman's terms, guided by a relatively simple set of subrules and principles that are explained to them in their training materials and online resources, and which are themselves based on ombudsman decisions. ${ }^{401}$ In this way, the fair and reasonable standard operates as a vehicle through which ombudsmen translate a relatively sophisticated standard into a more tractable set of principles and rules that can be implemented by less specialized bureaucrats.

\section{FROM THEORY TO REALITY: TOWARDS A PRIVATE INSURANCE OMBUDSMAN FOR THE UNITED STATES}

The FOS's success suggests several straight-forward reforms that could easily be accommodated within the United States' existing consumer insurance ADR structures. For instance, state insurance departments could be authorized to collect case fees, ${ }^{403}$ arbitrators' decisions could be published and publicly disseminated, ${ }^{404}$ and

399. See Interview with Walter Merricks, supra note 257 (explaining that adjudicators do not need to be lawyers to apply the fair and reasonable standard accurately).

400. Sec supra text accompanying notes 222-226 (describing adjudicators' application of the fair and reasonable standard).

401. See Gilad, supra note 179, at 232 ("Interviewees maintained that complaints were usually straightforward from a professional stance, involving simple and recurrent issues.")

402. In many ways, this is similar to the way in which the law of negligence is translated into a set of rules of thumb that insurance adjustors use to settle cases. See Ross, supra note 349 , at 134-35 (describing how vague standards such as negligence are translated into concrete rules of thumb by insurance companies in order to manage the volume of claims that claims handlers must deal with).

403. See supra text accompanying notes 336-341. State legislation could easily permit insurance departments to collect individual case fees from insurers for resolving their customers' complaints. Armed with this authority, insurance departments that have a twostage conciliation process-wherein initial calls are answered by one employee, and subsequent conciliation efforts are taken up by a second employee-could make payment of the case fee contingent on the insurer's refusal to settle at the first conciliation stage. See supra text accompanying note 81 . In fact, such a scheme would simply be one variation on Minnesota's procedure of excluding from insurers' complaint ratio disputes that insurers quickly resolve. See supra text accompanying note 95 .

404. Lawmakers could follow the FOS and require that insurance arbitrators publish their decisions and make those decisions available to regulators. As noted earlier, arbitrators in other fields, such as labor and employment, already publish their decisions as a matter of course. See supra text accompanying note 161. In fact, California already requires arbitrators in medical service agreements to issue a written decision that must be provided to the insurance department and made publicly available upon request. See CAL. HEALTH \& SAFETY CODE $§ 1373.21$ (Deering 2008). 
insurers' internal complaint handling rules could be strengthened. ${ }^{405}$

To be sure, each of these incremental reforms would probably help to improve consumer insurance ADR in America. But simply cherry-picking individual elements of the FOS scheme that can easily be mimicked within our own institutional framework misses the larger lesson that the private ombudsmen model offers. No single policy or practice accounts for a significant percentage of the FOS's success. Rather, it is the FOS's institutional architecture that explains the stark discrepancies in outcomes between the American and British systems for resolving consumer insurance disputes. This architecture coordinates the different stages of ADR and leverages the FOS's ultimate authority in order to promote settlement at each of the earlier stages. $^{406}$ It also ensures the FOS's neutrality, while promoting dialogue and communication with regulators, industry, and consumers. ${ }^{407}$

Indeed, many of the nonstructural reforms described above contribute to the FOS's success precisely because they support and complement the organization's institutional structure. For instance, the rules governing insurers' internal complaint handling promote early settlement in the United Kingdom because of the way they fit within the larger FOS framework. The FOS's regular review of internal complaint files in the course of resolving disputes and its authority to bind insurers to adverse outcomes both help to ensure that firms take seriously the internal complaint handling process. ${ }^{408}$ Similarly, the publication of ombudsman decisions helps to promote a coherent, and consistent, standard of review in part because of the FOS's larger institutional framework. Such consistency would be quite difficult were ombudsmen not part of a single organization that actively promotes an institutional culture of neutrality, independence, and fairness. ${ }^{409}$

Although the FOS model may offer few "quick fix" policy reforms, the big-picture structural lessons that it does offer are less

405. State regulators could easily improve the rules governing insurers' internal complaint handling. See supra text accompanying notes 73-76. They could expand the definition of a complaint and require insurers to provide written explanations to such complaints within a specified time period. These responses could then automatically form the basis of any subsequent conciliation by the regulator. See supra text accompanying notes 193-199.

406. See supra Part IV.A.

407. See supra Parts IV.B-C.

408. See supra text accompanying notes 342-353.

409. See supra text accompanying notes $354-376$. 
daunting than they may initially appear. Because so many of the constitutive elements of the FOS resemble $\mathrm{ADR}$ approaches that are already used in American insurance contexts, implementing an American scheme based on the FOS would merely involve rearranging existing ADR pieces rather than funding and developing those pieces out of whole cloth. For instance, an interested jurisdiction could begin simply by removing part of the consumer affairs division from its insurance regulator and hiring several attorneys or insurance experts who might otherwise be arbitrators. Some of the legal infrastructure for this new entity could be borrowed from the rules that already govern external review and appraisal. These might include regulations governing internal review of complaints, when parties must submit documents for review, and when (and if) they can request a hearing. Of course, these sources might provide limited guidance in a few areas, and here policymakers could turn to the provisions of the Financial Services Markets Act that created the FOS in 2000.

American jurisdictions could adopt these basic elements of the FOS scheme without embracing its most politically untenable elements. For instance, an American scheme could employ an ombudsman/arbitration stage that was binding on both consumers and insurers, rather than only binding on insurers. As discussed earlier, such an approach might be necessary given the differences in the background insurance law regimes of the United Kingdom and United States. ${ }^{410}$ In particular, the potential for punitive damages in the United States could cause successful applicants to an American private ombudsman that did not bind consumers to try their luck in litigation, leading to duplicative resources being devoted to the dispute resolution process. ${ }^{411}$

The legal obstacles to such reform would likely be minimal. The United States Constitution does not mandate any particular procedure for resolving disputes. As long as each party is afforded meaningful notice and opportunity to be heard, "a state may choose the remedy best adapted, in the legislative judgment, to protect the interests concerned." ${ }^{, 42}$ For this reason, even a scheme that replicated the FOS's

410. See supra text accompanying notes 261-265.

411. This would be an extreme form of the problem with consumer opt out identified by Estreicher and others. See supra text accompanying note 255 .

412. See Hardware Dealers Mut. Fire Ins. Co. v. Glidden Co., 284 U.S. 151, 158 (1931); see also Hamdi v. Rumsfeld, 542 U.S. 507, 533 (2004); Fuentes v. Shevin, 407 U.S. 67, 80 (1972). Applying this principle in Hardware, the Supreme Court upheld Minnesota's appraisal requirement for fire insurance policies. 284 U.S. at 158. The FOS has itself been 
asymmetric authority to bind insurers, but not policyholders, would likely survive challenge. ${ }^{413}$ Similarly, an FOS-like scheme would pose few state constitutional problems. Although the jury trial rights of state constitutions have proven to be a major obstacle to tort reform, ${ }^{414}$ they would not interfere with an FOS scheme. Consumers would face no deprivation of their jury trial right as long as they could opt for litigation after the dispute arose, as is the case with the FOS. ${ }^{415}$ Insurers would similarly have no viable jury-trial claim. Because they are "affected with a public interest," insurers are routinely subject to regulation that might otherwise impair constitutional rights. ${ }^{416}$ Just as insurers do not suffer an unconstitutional taking when their rates are regulated, they would not be deprived of their jury-trial right by regulation of their claims dispute resolution process.

By contrast, the political obstacles to reform based on the FOS are likely to be significant. As Howell Jackson has demonstrated, political differences help to explain why the United Kingdom was so much more successful than the United States in radically modernizing its financial regulation in the late 1990 s. $^{418}$ Political differences might likewise render an FOS-like scheme politically infeasible in the United States. In particular, the United States has an entrenched culture of "adversarial legalism," which includes lawyer-dominated litigation to

challenged on Due Process grounds. See Paul McMillan, FOS Says It's Flavour of the Month for Legal Challenges, MONEY MARKETING, Oct. 5, 2006, at 8.

413. The asymmetry would not pose any obvious Due Process concerns, as both insurers and consumers retain a meaningful right to be heard. See George Rutherglen, Better Late Than Never: Notice and Opt Out at the Settlement Stage of Class Actions, 71 N.Y.U. L. REv. 258, 266 (1996) (noting that no Due Process challenge was ever levied against the old "one-way intervention" class action procedure, wherein class members could "benefit from a favorable judgment but escape the preclusive effect of an unfavorable judgment"). 2007).

414. See Kenneth S. Abraham, The Forms and Functions of Tort LaW (3d ed.

415. A fundamental element of the right to a jury trial is that it can be waived. A postdispute opt out may not even be necessary to accomplish waiver. Some courts have held that consumers can waive their jury-trial rights voluntarily simply by signing an insurance policy, rejecting "contract of adhesion" arguments. See, e.g., Meyer v. State Farm Fire \& Cas. Co., 582 A.2d 275, 276-78 (Md. Ct. Spec. App. 1990). As argued above, though, consumer opt out is essential for consumer protection reasons. See supra text accompanying notes 253-255.

416. German Alliance Ins. Co. v. Lewis, 233 U.S. 389, 406-88 (1914); see also O'Gorman \& Young, Inc. v. Hartford Fire Ins. Co., 282 U.S. 251, 257 (1930).

417. See German Alliance, 233 U.S. 389.

418. See Jackson, supra note 180, at 7 ("The highly decentralized structure of traditional financial regulation in the United States creates numerous constituencies inclined to resist any efforts to make major changes in regulatory structures."). 
resolve disputes. ${ }^{419}$ This culture would clash directly with an FOS scheme that sought to move dispute resolution into a more bureaucratic and inquisitorial setting.

Despite these difficulties, there are reasons to believe that an FOS scheme could prove politically viable in the United States. First, and most importantly, because the states currently regulate insurance, only a single state must be convinced to embrace an FOS-like scheme. Once a state did so, others could observe the results and adopt it if it proved successful. Moreover, a private ombudsman could be offered at the federal level, in tandem with one of the new federal insurance regulatory schemes that have been proposed in recent months. ${ }^{420}$ In a climate where a new federal insurance regulator is being designed from scratch, supplementing it with an FOS-like scheme would have no impact on entrenched agencies or procedures. ${ }^{421}$

Second, the British experience suggests that the insurance industry - the most significant potential opponent of an FOS-like approach-could be convinced to endorse such a scheme. Indeed, British insurers overwhelmingly support the FOS as a valuable mechanism for enhancing consumer confidence in the industry. ${ }^{422}$ Thus, the British Insurance Association, after surveying its members, found:

The industry perceives that the FOS plays a key role in providing consumers with a complaints resolution service that is free to the consumer, easy to understand and non-legalistic in its approach. This helps underpin consumer confidence in financial services and avoids lengthy court processes that would add to costs.

Part of the reason for this industry support is that the FOS helps to manage "the public's excessive or unrealistic expectations" of coverage by "communicating adverse decisions to complainants in a sensitive

419. See generally ROBERT A. KAGAN, ADVERSARIAL LEGALISM: THE AMERICAN WAY OF LAW 4 (2001) ("[A]dversarial legalism is deeply rooted in the political institutions and values of the United States. Americans are not likely to accept wholesale replacement of familiar legal rights and practices by legal institutions drawn from rather different political traditions.").

420. E.g., Scott, supra note 6.

421. But see Jackson, supra note 180, at 6-10 (suggesting that entrenched agency powers were a significant impediment to more substantial financial reform in the late 1990s, whereas the British avoided this infighting in the design of the FSA by providing "guaranteed continuity of employment for all regulatory personnel over the course of the consolidation process").

422. See supra text accompanying note 372 .

423. See Ass'n of British Insurers, supra note 272. 
and persuasive manner" that emphasizes its "independence from firms." ${ }^{424}$

Finally, the evolution of the FOS in the United Kingdom demonstrates that legislative mandate is not the only way in which such a scheme could develop. Rather, it was the insurance industry in the United Kingdom that forged the private ombudsman approach. Accounts of insurers' motivations for doing so differ. ${ }^{425}$ But at least one contributing factor seems to have been the prospect of legislative action if the industry did not itself act. ${ }^{426}$ American lawmakers could similarly design inducements, both positive and negative, to encourage insurers to cooperatively design their own private ombudsman. Alternatively, because a privately operated scheme would have some drawbacks, lawmakers could experiment with trying to induce insurers to comply voluntarily with a state-run private ombudsman scheme. In either case, lawmakers might, for instance, consider allowing insurers to avoid bad-faith claims as an inducement to action. States without a bad-faith doctrine could do the opposite, threatening to adopt such rules in the absence of an FOS-like approach. ${ }^{427}$ In the end, the potential that more effective ADR could both mitigate litigation costs and buttress consumer confidence makes the prospect of such reform more realistic than it might initially appear.

Ultimately, the FOS is a product of a unique British history and culture. For that reason, its success may not be easily replicated in the United States. For instance, it may be that the FOS's origin as a voluntary scheme among insurers imbued it with a credibility that is entirely path dependent and cannot be replicated here. But the sheer scope of the FOS's success-both across all consumer financial services in the United Kingdom and across geographic regions ranging from Japan to India and much of Europe-minimizes these objections. At the very least, it provides a sufficient case for state experimentation with an American private insurance ombudsman modeled on the FOS. Such experimentation is itself an important element of effective

424. See Gilad, supra note 179, at 228-29, 238-41. Complaint handlers accomplish this not only by focusing on their independence but also by making written communications clear, grammatically correct, and informal and friendly, as well as reflecting an understanding of the basis for the complaint. See id. at 233, 235, 238.

425. See generally Tyldesley \& Paruk, supra note 9 (reviewing the history of the initial insurance ombudsman bureau).

426. See id.

427. Another option is that lawmakers could require insurers who reject the recommendations of complaint handlers to (1) fund a set amount of attorneys' fees upfront in such cases and/or (2) provide subsistence payments to policyholders during the course of any such litigation. 
dispute system design, and should be conducted with an eye towards "testing and evaluating the design to make appropriate revisions." $\$ 28$

If a private ombudsman scheme were successful in the insurance realm, the implications would be significant for all consumer financial services. As in the United Kingdom, the private ombudsman model could evolve well beyond insurance, representing a new method for resolving virtually any consumer financial dispute. Indeed, as in insurance, the basic infrastructure for a private ombudsman scheme already exists in the banking and securities realms. The Office of the Comptroller of the Currency has a Customer Assistance Group that largely mirrors state insurance regulators in terms of the complaint conciliation services it provides. ${ }^{429}$ The Securities \& Exchange Commission similarly provides limited consumer complaint services to investors via its Office of Investor Education and Advocacy. ${ }^{430}$ Many of the lessons that the FOS offers for insurance may therefore be applicable to a wide range of consumer financial disputes.

428. Franck, supra note 13, at 178 (summarizing the basic process of dispute system design, and listing such experimentation as the fourth, and final, stage of effective dispute system design).

429. See Contact OCC's Customer Assistance Group, http://www.helpwithmybank. gov/contactus/index.html (last visited Nov. 16, 2008). Interestingly, the Customer Assistance Group is actually a subdivision of the Office of the Comptroller of the Currency (OCC) ombudsman. The ombudsman was initially a traditional ombudsman's office that was primarily tasked with dealing with bankers' complaints about the OCC itself. See OFFICE OF THE COMPTROLLER OF THE CURRENCY, REPORT OF THE OMBUDSMAN 2005-2006, at 7-27 (2007), available at http://www.occ.gov/Ombudsman/2006OmbudsmanReport.pdf.

430. See U.S. Sec. \& Exch. Comm'n, How the SEC Handles Your Complaint, http://www.sec.gov/investor/pubs/howoiea.htm (last visited Nov. 16, 2008). 